\title{
Indeterminacy and Incommensurability in Constitutional Law
}

\author{
Steven L. Winter
}

TABLE OF CONTENTS

I. Law "and" Theory .............................. 1444

II. Paradigms Regained ............................ 1448

III. The Lessons of Constitutional Law in the Modern Age..... 1454

A. The Legal Realist Precedent ..................... 1454

B. The Politics of Indeterminacy .................. 1466

C. The Instability of Normal Science................ 1469

IV. The Mearings of Constitutional Politics................ 1473

A. The Politics of Epistemia ...................... 1473

B. The Politics of the Subject ..................... 1476

C. The Meaning of Situatedness................... 1485

D. Constitutional Politics .......................... 1494

1. Normative Dialogue and Transformative Action ... 1494

2. The Role of Scholarship .................... 1500

V. The Situated-Subject's Guide to the Constitution .......... 1505

A. Avoiding the Subject/Object Dichotomy .......... 1507

1. The Incominensurability Objection ............. 1507

2. The Historicist Objection....................... 1509

B. Relentless Jurisgenesis ........................ 1511

1. Jurisgenesis in Action ...................... 1511

2. Trimorphic Constitutionalisin ................. 1513

a. Ackerman's Dualist Democracy.............. 1513

b. Three-Track Jurisgenesis................. 1515

c. Coming Up Short I: Reconstruction and the Problem of Method...................... 1516

d. Coming Up Short II: The New Deal and the Problem of Scope ...................... 1518

e. A Trimorphic Exemplar .................. 1520

C. Reconstitutive Constitutionalisin ................ 1522

1. A Matter of Interdependence-West Coast Hotel ... 1523

2. The Social Construction of the Subject-Brown .... 1527

3. Everything's Connected to Everything ElseGriswold ................................. 1534

VI. Wearing Out the Sheath......................... 1539 



\title{
Indetermmacy and Incommensurability m Constitutional Law
}

\author{
Steven L. Winter $\dagger$
}

Progressive constitutional scholarship has yet fully to confront the implications of the conservative shift in constitutional law. Liberal critics continue to seek governing constitutional theories with which to constrain decisionmaking by judges of a notably different mind. Other, more radical scholars employ the indeterminacy and "law is politics" critiques in a more open attempt at displacement. Neither approach is viable, however. Each presumes the primacy of the autonomous, self-directing subject; each resists recognition of the situated nature of all human endeavor. This essay adopts the alternative strategy: exploring the implications of situatedness as they apply to the development, practice, and attempted reconstruction of modern constitutional law. After evaluating the lessons of history, the essay suggests a reconceptualization of "constitutional politics" which better reflects the parameters that both limit and enable change. It explores the possibilities for reconstruction through revisionist readings of three familiar cases-West Coast Hotel v. Parrish, Brown v. Board of Education, and Griswold v. Connecticut. These rereadings reveal not only that the recognition of situatedness and its constitutional implications are already a part of the canon, but also that they are the very center of modern constitutional concern.

Copyright $\odot 1990$ by Steven $L$. Winter. All rights reserved.

$\dagger$ Professor, University of Miami School of Law; Visiting Professor, Yale Law School. B.A. 1974, Yeshiva College; J.D. 1977, Colunbia University. I am grateful to Mark Tushnet and Mike Seidman for inviting ine to the symposium for which an earher version of this paper was first prepared. Since this essay is about situatedness, it is particularly appropriate to acknowledge that inany of these ideas were generated in correspondence and conversation with Pierre Schlag, Mark Tushnet, Mark Johnson, Milner Ball, Fred Schauer, and Bruce Ackerman. I am grateful to them and to Frank Michehnan, Paul Kahn, George Lakoff, Steve Schnably, Mike Fischl, Jereiny Paul, Jennifer Jaff, Pat Gudridge, and Lynn Winter for their comments and suggestions.

This essay is dedicated to the ineunory of my friend Malcolm Rucker. 
The blade wears out the sheath, and in the end no one is satisfied, neither the philosopher nor the powers that be. ${ }^{1}$

\section{I \\ LAW "AND" THEORY}

Not long ago, I was invited to a syinposium with the deceptively simple title, "Constitutional Law and Theory in a Conservative Era." The implicit question-"What are we to do?"--seemed straightforward enough, however obscure the answer might be. Yet the more I pondered the title, the inore difficult I found the whole idea. First, I kept inserting into the title the word "practice" (as, in fact, I did once again when I sat down to write this). Perhaps this merely reflects the lingering effects of eight years of it. But checking the invitation didn't really help. For, once I wrestled the word "theory" back into place, I began to fixate on the word "and." This is embarrassimg, I thought. Why am I having such difficulty with this simple title? But then I realized that, depending on how one reads the seemingly innocent word "and," the questions put by the title could be quite different. In fact, I asked myself: What is the subject? Constitutional law, or constitutional theory, or both, or the relations between the two? Or is it constitutional-law-and-theory as a unitary subjeet? ${ }^{2}$

Imagine my einbarrassinent over having so coinphicated such a simple matter. But then I realized that there was soinething more profound at work, something peculiarly of our time. I began to focus on the "and" and the way it both mediates and holds apart the words that flank it. In domg so, I saw that the disjunctive effect of this "and" overwhelins its simple conjunctive ineaning just as the predicaunent of constitutional theory in a conservative era overshadows the ordinary assumption that judges and constitutional law scholars are engaged in more or less the same enterprise. This disjunctive "and" suggests, therefore, that the problems of constitutional law and theory in a conservative era are problems of incominensurability-that is, the quite substantial risk that the two will not talk to each other.

Even if it were a smiple conjunction, this "and" would nevertheless present the question of the relations between law and theory, generally, and between constitutional law and constitutional theory in a conservative era, specifically. We might conclude that law is driven and controlled by theory (of the Grand Theory type), and then concentrate on getting just the right governing theory to coinbat the reigning conserva-

1. M. Merleau-Ponty, Adventures of the Dialectic 72 (J. Bien trans. 1973) [hereinafter M. MERLEAU-PONTY, DIALECTIC].

2. It did occur to me, of course, that the ambiguity was intentional and designed to keep the subject of the symposium radically indeterminate. 
tism. Or we might conclude that theory actually follows the law, that theory is an ex post rhetorical product culled from the contingent artifacts of constitutional decisionmaking. In that case, the challenge would be either to construct the best constitutional rhetoric with which to persuade others in normative dialogue or to deconstruct the constitutional discourse that currently holds sway on the Court. But, in a conservative era, this choice would leave us between a constitutional Scylla and Charybdis: either mired in the hopeless task of synthesizing Warren Court precedents into coherent theories that could bind or persuade a Court of a radically different mind; ${ }^{3}$ or condemned to the reactive task of de-synthesizing Rehnquist Court precedents in an effort to undermine its program and to persuade others (presumedly political actors) that it lacks legitimacy.

If this picture seems bleak, it should seem equally familiar. What I have sketched above is the outline of the current debate among liberal-toleft legal scholars. On one side, we have governing theories like Ronald Dworkin's concept of law as integrity; ${ }^{4}$ Bruce Ackerman's notion of amendment outside article $V$ as an exercise of an extraconstitutional popular sovereignty; ${ }^{5}$ John Hart Ely's notion of representation-reenforcing review; ${ }^{6}$ the recent republican revival that seeks to ground adjudication in "civic virtue" and "public values"; 7 and Michael Perry's conception of constitutional decisionmaking as inorally driven. ${ }^{8}$ On the other side, we have an increasing array of indeterminacy and "law is politics" arguments that attempt to expose the constructed and contingent nature of law itself and, thus, to challenge the legitimacy of its current inanifestations. This critical camp is by no means monolithic, although its members and their positions are readily identifiable. The most inoderate

3. This characterization, of course, is Mark Tushnet's description of mainstream constitutional law scholarship. See M. TUSHNET, RED, WHTE AND BlUE: A CRITICAL ANAIYSIS of CONSTITUTIONAL LAW at vii (1988); Tushnet, Character As Argument, 14 LAw \& Soc. INQUIRY 539, 539 n.1 (1989).

4. R. DWORkIN, LAw'S EMPIRE 225-28 (1986).

5. Ackerman, Constitutional Politics/Constitutional Law, 99 YALE L.J. 453 (1989) [hereinafter Ackerman, Constitutional Politics]); Ackerman, The Storrs Lectures: Discovering the Constitution, 93 YALE L.J. 1013 (1984) [hereinafter Ackerman, Storrs Lectures]. I discuss Ackerman's work in greater detail at infra text accompanying notes 371-418 and 444-521.

6. J. Ely, Democracy and Distrust: A Theory of Judicial Review (1980). For a particularly thoughtful critique of Ely, see Regan, Community and Justice in Constitutional Theory, 1985 WIS. L. REV. 1073.

7. See, e.g., Michelman, The Supreme Court, 1985 Term-Foreword: Traces of SelfGovernment, 100 HARv. L. REV. 4 (1986); Sunstein, Interest Groups in American Public Law, 38 STAN. L. REV. 29 (1985); Fiss, The Supreme Court, 1978 Term-Foreword: The Forms of Justice, 93 HARV. L. REV. 1 (1979). Aspects of Michelman's work are discussed at infra text accompanying notes 173-226.

8. M. Perry, The Constitution, The Courts, AND Human Righis (1982); see infra text accompanying note 171 . 
position is that of Cass Sunstein in his Lochner's Legacy piece; ${ }^{9}$ the inost radical is that of Mark Tushnet in his extensive oeuvre; ${ }^{10}$ and the inost coinprehensive stateinent is presented in Stone, Seidinan, Sunstein, and Tushnet's Constitutional Law. ${ }^{11}$

Regardless of whether we take the route of governing theory or of theory as rhetorical product, our simple conjunctive "and" has already driven a wedge between constitutional law and theory. Whichever approach we take, we have already separated law from theory and placed the latter on the outside trying to get back in. ${ }^{12}$ This separation is unavoidable in the case of governing theory, which inust be autonomous and discrete if it is to be able to constrain constitutional decisionmaking. But much the saine is true of theory-as-rhetorical-product: It is soinething that inust first be extracted froin past decisions and then reintroduced to the debate in an effort to persuade current actors. Indeed, in its inainstream form, theory-as-rhetorical-product is expected to work much like governing theory-that is, it inust be external to the contemporaneous conservative practices of constitutional law if it is to be successful as a rhetorical force powerful enough to persuade today's conservative judges to change position.

But what about constitutional theory's more radical inanifestations? Don't they avoid these probleins? After all, the whole idea is to decline to exert a direct influence on the current practices of constitutional decisionmaking and, instead, to undermine or supplant thein altogether. But in that very sense, the wedge between constitutional law and theory is as deep and real as it can be. The two don't talk to each other at all.

Stanley Fish contends that this wedge is endemic because theory and practice are entirely distinct activities. ${ }^{13}$ But that is not my point.

9. Sunstein, Lochner's Legacy, 87 CoLUM. L. REv. 873 (1987). Aspects of his article are discussed at infra notes $79,405,427-42$ and accompanying text.

10. See, e.g., M. TushNET, supra note 3; Tushnet, Following the Rules Laid Down: A Critique of Interpretivism and Neutral Principles, 96 HARV. L. REV. 781 (1983) [hereinafter Tushnet, Following the Rules]; Tushnet, Darkness on the Edge of Town: The Contributions of John Hart Ely to Constitutional Theon, 89 YALE L.J. 1037 (1980).

11. G. Stone, L. Seidman, C. Sunstein \& M. Tushnet, Constitutional Law (1986).

12. "The objection to the concept of [law as politics] . . conceives of constitutional constraints as, is some sense, coming from the outside. The democratic position, in contrast, believes that the most effective constraints are those that coine from within." Tushnet, Principles, Politics, and Constitutional Law, 88 Mich. L. REv. 49, 81 (1989). I have tried to develop an expanded sense of what it might inean for coustraints to "coine from within," in a series of articles on law and cognitive theory. See Winter, The Metaphor of Standing and the Problem of Self-Governance, 40 STAN. L. REv. 1371 (1988) [hereinafter Winter, The Metaphor of Standing]; Winter, Transcendental Nonsense, Metaphoric Reasoning, and the Cognitive Stakes for Law, 137 U. PA. L. REv. 1105 (1989) [hereinafter Winter, Transcendental Nonsense]; Winter, The Cognitive Dimension of the Agon Between Legal Power and Narrative Meaning, 87 Mich. L. REv. 2225 (1989) [hereinafter Winter, The Cognitive Dimension]; Winter, Bull Durham and the Uses of Theory, 42 STAN. L. REv. 639 (1990) [hereinafter Winter, Bull Durham]. I return to this notion later, in Part IV.

13. See, eg., Fish, Dennis Martinez and the Uses of Theory, 96 YALE L.J. 1773 (1987); Fish, 
Fish's position depends, on one hand, on an entirely reified, objectivist view of theory and, on the other hand, on an excessively closed view of practice. ${ }^{14}$ Nor is it my point that theory and critique have had no impact on constitutional law. On the contrary, the critiques referred to above have had a lasting and, in some sense, irreversible impact on the way we understand constitutional law. Rather, I am claiming that, in a conservative era, the relations between theory and practice present formidable problems of incommensurability precisely to the extent that we, as biberal-to-left legal academics, would like theory to work as a check on, counterbalance to, or replaceinent for the current practices of conservative constitutional decisionmaking.

So how do we escape this constitutional Scylla and Charybdis? Although the critical legal studies critique of hiberal legalism has made important contributions, its concomitant adoption of the indeterminacy and "law is politics" arguments invites endless problems of skepticisin and incommensurability. To find a path through the maze, we need an alternate strategy, a strategy informed by a better understanding of our situation. To begin, we need an epistemological understanding that allows us to recognize the constructed nature of meaning without renouncing what is valuable in those constructions.

For this task, I turn to two extralegal sources-one familiar, the other not. The first is Thoinas Kuhn, whose influential account of the history of science reflects an integrated understanding of both the relativisin of human knowledge and the reality of scientific progress. ${ }^{15}$ The second is the French philosopher Maurice Merleau-Ponty. ${ }^{16}$ Although relatively unexplored in legal scholarship, ${ }^{17}$ Merleau-Ponty's work is

Fish v. Fiss, 36 STAN. L. REv. 1325 (1984). Both these essays are reprinted with several others in S. Fish, Doing What Comes Naturaliy: Change, Rhetoric, and the Practice of Theory IN LITERARY aNd LeGal Studies (1989) [hereinafter DoING What CoMes Naturally].

14. For the demonstration of this point, see Winter, Bull Durham, supra note 12, and Schlag, Fish v. Zapp: The Case of the Relatively Autonomous Self, 76 GEO. L.J. 37, 55-58 (1987).

15. T. KUHN, The Structure OF SCIENTIFIC Revolutions 167-73, 205-07 (2d ed. 1970).

16. Merleau-Ponty was a contemporary and companion of Jean-Paul Sartre. With Sartre, he was cofounder of the journal Les Temps modernes; he served as the political editor of the journal from 1945 to 1950. After the outbreak of the Korean War, Merleau-Ponty resigned from the journal, renounced his "wait-and-see" approacls to Marxism, and endorsed parhamentary democracy as "the only known institution that guarantes a minimum of opposition and of truth." M. MerleaU-Ponty, Dialectic, supra note 1, at 226; see id. at 227-33. For a helpful, nuanced introductiou to Merleau-Ponty's political thought, see K. WhITESIDE, MERLEAU-PONTY AND THE Foundation of an Existential Polmics (1988). For a development of Merleau-Ponty's philosophical thought (particularly his phenomenology of the body) as well as its connections to his political thought, see J. O'Neill, The Communicative Body: Studies in Communicative PhILOSOPHY, Politics, AND SOCIOLOGY (1989).

17. Authors in legal periodicals commonly cite Merleau-Ponty as one of the European phenomenologists. See, eg., Boyle, The Politics of Reason: Critical Legal Studies and Local Social Thought, 133 U. PA. L. REv. 685, 741-42 n.164 (1985); Rubim, The Practice and Discourse of Legal Scholarship, 86 Mich. L. REv. 1835, 1835 (1988). Merleau-Ponty also appears in references to 
appropriate to our concerns for two interrelated reasons. In his philosophical writings, Merleau-Ponty recognized both the unavoidably perspectival nature of our experience-which is always experience froin within a cultural and historical situation-and, at the same time, he rejected the Cartesian skepticisin and Sartrean freedoin that follow from traditional views of subject-object relations. ${ }^{18}$ In his pohtical writings, Merleau-Ponty faced a political dilemma strikingly similar to our own: that of constructing a pohtics which simultaneously avoids the limitations of hiberalism and the failures of Marxism (both Sartrean and otherwise). ${ }^{19}$ In the Sections that follow, I draw heavily on Kuhn and Merleau-Ponty in arguing for a view of constitutional law that inore fully appreciates the implications of our situatedness and its role in shaping both the possibilities of meaning and the difficulties of change.

\section{II}

\section{Paradigms Regained}

The indeterminacy critique seeks to unmask legal doctrine for the social construction that it is. The critique assumes that, in the absence of a forinalist view of language as an acontextual reference to objective reality, ${ }^{20}$ law can only function as a cover for politics. In a sense, the inde-

Marxism. See, e.g., Schlag, An Attack on Categorical Approaches to Freedom of Speech, 30 UCLA L. REV. 671, 679 n.29 (1983); Richards, Book Review, 60 N.Y.U. L. REV. 1188, 1192-93 (1985).

Although occasional substantive references to Merleau-Ponty's philosophical work appear in the legal literature, these references are usually isolated and undeveloped. See, e.g., Collier, Precedent and Legal Authority: A Critical History, 1988 WIs. L. Rev. 771, 796 n.112; Van Zandt, The Relevance of Social Theory to Legal Theory, 83 Nw. U.L. REv. 10, 27 n.85 (1989). An exception is Mootz, The Ontological Basis of Legal Hermeneutics: A Proposed Model of Inquiry Based on the Work of Gadamer, Habermas, and Ricoeur, 68 B.U.L. REV. 523 (1988) (relying on MerleauPonty's phenomenology of perception to complement his development of a legal hermeneutics).

My discussion of Merleau-Ponty does not pretend to assess thoroughly his philosophical and political thought. Merleau-Ponty produced a substantial and difficult written corpus-at least ten books are available in English translation. Moreover, his philosoplical thought shifted in important ways during the 1950s, inoving from an emplasis on a philosophy of history to a Saussurean view of language. Despite these important shifts, there are continuities in his philosophical thouglit that bear upon the concerns of this essay-particularly in his effort to get beyond the subject/object duality and the relation of this issue to the problems of politics. See generally $\mathrm{K}$. WHITESIDE, supra note 16 (general discussion of Merleau-Ponty's writings).

For a different applieation of Merleau-Ponty's thought to law, see W. HAMRICK, AN Existential Phenomenology of Law: Maurice Merleau-Ponty (1987). I have reservations about Professor Hamrick's approach, which both empliasizes different aspects of Merleau-Ponty's thought and, inore importantly, is premised on an understanding of law that is substantially at odds with my experience of it.

18. See, e.g., M. Merleau-Ponty, Phenomenology of Perception (C. Smith trans. 1962) [hereinafter M. Merleau-Ponty, Phenomenology].

19. See, eg., M. MERLEAU-PONTY, Dialectic, supra note 1. See generally K. Whiteside, supra note 16.

20. Frederick Scliauer has argued that there can be literal meaning and acontextual reference-and, therefore, formalist law. Schauer, Formalism, 97 YALE L.J. 509 (1988). In a previous work, lowever, I pointed out that even the simplest terms come with culturally relative 
terminacy critique is half correct: Much of the rhetoric of legal decisionmaking seems to promise a neutrality and objectivity that it does not deliver. But after the indeterminacy critique has done its quite valuable work of unmasking the law's veneer of objectivity, what remains becoines a self-consuming artifact. If social construction is all there is, then where is the critical charge? A socially constructed law is only to be faulted as such if one is holding out for soinething more, soinething truly objective.

What the indeterminacy critique misses, moreover, is the stubborn fact that our way of being-in-the-world is - contingently-to construct certainty all over the place. And we do so without respite.

On the pretext that every rational or linguistic operation condenses a certain thickness of existence and is obscure for itself, one concludes that nothing can be said with certainty. On the pretext that human acts lose all their meaning when detached from their context and broken down into their component parts (like the gestures of the man I can see but do not hear through the window of a telephone booth), one concludes that all conduct is senseless. It is easy to strip language and actions of all meaning and to make them seem absurd, if only one looks at them from far enough away .... But that other miracle, the fact that, in an absurd world, language and behavior do have meaning for those who speak and act, remains to be understood. ${ }^{21}$

A critical constitutional theory that stakes its hopes on the indeterminacy critique has foreordained its own marginalization, because the question is not whether there is ineaning, but rather how there is meaning and what that meaning is.

We can begin to answer these questions only if we reject both the belief that ineaning has foundations im objective correspondence with the world and the contrasting view that ineaning can be nothing inore than the arbitrary result of unconstrained subjectivity. ${ }^{22}$ This double renunciation lias profound miplications for constitutional law and its theory. The repudiation of objectivisin carries with it a firm rejection of the determinacy of the analytic logic that ordinarily dominates the surface of constitutional law and theory. ${ }^{23}$ At the same time, the repudiation of

values and contextual assumptions already built into their "literal" meaning. Winter, Transcendental Nonsense, supra note 12, at 1178-80 (discussing H.L.A. Hart's proverbial rule prohibiting "vehicles" in the "park"); see also Winter, An Upside/Down View of the Countermajoritarian Difficulty, 69 TEx. L. REv. (forthcoming June 1991) [hereimafter Winter, Upside/Down View].

21. M. Merleau-Ponty, Sense AND Non-Sense 39 (H. Dreyfus \& P. Dreyfus trans. 1964) [hereinafter M. MERLEaU-Ponty, SENSE AND NoN-SENSE].

22. I lave elaborated and defended the premises that underlie this approach to meaning and rationality in the series of articles cited supra note 12 .

23. For explanations of why the model of analytic rationality cannot work without objectivist foundations, see Winter, Bull Durham, supra note 12, at 650-53; Winter, Transcendental Nonsense, supra note 12, at 1107-10. For alternative presentations of constitutional doctrine in terms of 
pure subjectivism entails a consequent rejection of the view that law is only imstrumental and pohtical.

For many, these renunciations may seem mutually contradictory or even absurd: Either the object constrains the subject, or the subject must command the object; if the analytic logic of the discipline (whether law or theory) does not yield objective results, then it must follow that all outcomes are subjective and politically motivated. But these alternatives are only exhaustive if one holds to the distorting perspective of the traditional subject/object dichotomy tliat, in one way or another, frames much of the current legal debate. ${ }^{24}$ The quandary of constitutional theory in a conservative era is a perfect exanple of the consequences of this distortion: By separating and privileging theory over practice, inainstream theory merely reenacts the subject/object dichotomy in yet anotlier mconclusive inuddle. It sliould provide an abject lesson of the dangers to legal thought posed by the subject/object duality and the litany of exhausted and discredited dicliotomies tliat it entails-like fact/ value, mimd/body, internal/external, public/private, freedom/constraint, reason/passion, and so forth. ${ }^{25}$

In place of this naive, two-dimensional picture of subject-object relations, we need a more complex conception of the situated nature of all liuman endeavor - mcluding coginition. "[W]e are through and through compounded of relationships with the world . ..."26 Meaning arises in

nonobjectivist models, see id. at 1186-95 (first amendment); id. at 1199-206 (congressional commerce clause power); Winter, The Metaphor of Standing, supra note 12, at 1386-93, 1458-78 (standing doctrine).

24. See Winter, Transcendental Nonsense, supra note 12, at 1107-13. Indeed, the underlying assamption of the subject/object dichotomy is what unites objectivism and subjectivism. In this sense, subjectivism is itself dependent on and a product of objectivist assumptions. See M. Merleau-Ponty, Phenomenology, supra note 18, at 39 ("We pass from absolute objectivity to absolute subjectivity, but this second idea is no better than the first and is upheld only against it, which means by it. The affinity between intellectualism [i.e., idealism] and empiricism [i.e., objectivism] is thus much less obvious and much more deeply rooted than is commonly thought.").

25. Cf. M. Merleau-Ponty, Signs 226-27 (R. McCleary trans. 1964) [heremafter M. MERLEAU-PoNTY, Signs]:

There were values and, on the other hand, realities; there was mind and, on the other hand, body; there was the interior and, on the other hand, the exterior. But what if it were precisely the case that the order of facts imvaded that of values, if it were recognized that dichotomies are tenable only this side of a certain point of misery and danger? ...

Our century has wiped out the dividing line between "body" and "mind," and sees human life as through and through mental and corporeal, always based upon the body and always (even in its most carnal modes) interested in relationships betwecn persons.

See also W. HAMRICK, supra note 17, at 24-25 (For Merleau-Ponty, "the mcarnation of form or structure effectively generates a philosophy dedicated to moving away from a number of parallel dualisms: mind and body, subject and object, perceiver and perceived, and the internal and the external.").

26. M. Merleau-Ponty, Phenomenology, supra note 18 , at xiii.

The world is not an object such that $I$ have in my possession the law of its making; it is the natural setting of, and field for, all my thoughts and all my explicit perceptions. ... [T] is no inner man, man is the world, and only in the world does he know himself. 
the imaginative interaction of the human organisin with its world, and all meaning is grounded in this experience. ${ }^{27}$ We begin with the generalization of rudinentary interactions with the world into inental constructsinodels, inetaphors, and schemata-that provide a measure of apparent umity and determinacy in our experience of the world. ${ }^{28}$ Thus, we represent the phenomenon of law in terms of our own embodiment: A body of decisional law-the corpus juris-consists of seminal cases and their progeny; our nost basic legal principles are embodied in constitutions or statutes. ${ }^{29}$ Intersubjective meaning-including communication-is possible in part because we are similarly einbodied bemgs interacting with the same general enviroument. ${ }^{30}$

We also exist in time. The physical and social world in which we are situated is constantly in flux. Meaning, reference, and rationality are all possible, but problematic. Humans cope by stabilizimg contexts so that they can commumicate, interact, and contend with one another in a predictable-and, therefore, relatively safe-inanner. ${ }^{31}$ Because some measure of commumication, cooperation, and constraint on conflict are necessary to survival-especially in an industrialized, highly interdependent civilization-humans have a substantial investment in maintaining this relative stability. ${ }^{32}$

\section{Id. at xi.}

27. See id. at 440 ("[I]f I elect to see things from the point of view of Sirius, it is still to my terrestrial experience that I must have recourse in order to do so . . . ."); M. MERLEAU-PoNTY, SENSE AND NON-SENSE, supra note 21, at 24 ("There can be no consciousness that is not sustained by its primordial involvement in life and by the manner of this involvement.").

28. M. Johnson, The Body IN THE MIND: THE Bodily Basis of MeANing, IMAgination and Reason 29 (1987); G. LakofF, Women, Fire, and Dangerous Things: What Categories Reveal About the Mind (1987). This material is discussed and explained in Winter, Transcendental Nonsense, supra note 12, at 1129-59.

29. For a discussion of the genesis and systematicity of these and related metaphoric conceptions of law, see Winter, Transcendental Nonsense, supra note 12, at 1207-24.

30. Id. at 1133-36 (shared experiences "motivate" communication); see also M. MERLEAUPONTY, Phenomenology, supra note 18, at 440:

In so far as I have hands, feet, a body, I sustain around me imtentions which are not dependent upon my decisions and which affect my surroundings in a way I do not choose. These intentions are general ... [in] that they are not of my own making, they originate from outside me, and I ain not surprised to find them in all psycho-physical subjeets organized as I am.

31. See P. Berger \& T. Luckmann, The Social Construction of Reality: A Treatise IN THE SOCIOLOGY OF KNOWLEDGE 57 (1966).

32. "The inherent instability of the human organism makes it imperative that man himself provide a stable environment for his conduct." Id. at 50; see also W. HAMRICK, supra note 17, at 27 ("[T]he social world ... is organized so as to achieve and maintain an equilibriunt with one's enviroument."); cf. C. Peirce, The Fixation of Belief, in The Philosophy of Peirce: Selected WRITINGS 5, 10 (J. Buchler ed. 1940):

Doubt is an uneasy and dissatisfied state froin which we struggle to free ourselves and pass into the state of behief; while the latter is a calm and satisfactory state which we do not wish to avoid, or to change to a betief in anything else. On the contrary, we cling tenaciously, not merely to believing, but to beheving just what we do behieve. 
Nevertheless, the maintenance of these stabilized contexts is not merely or even primarily an act of intersubjective will. It is, rather, a function of the grounded nature of the cognitive process. Because these socially constructed contexts necessarily precede any given individual, each of us is unavoidably situated in already existing social practices and conditions that form both the grounds of intelligibility for and the horizons of our world. As a result, our very ability to construct a world is already constrained by the cultural constructs within which we are situated. ${ }^{33}$ Thus, in a crucial sense, the grounded nature of our cognition means that we unconsciously reproduce and maintain the stabilized, socially constructed contexts $\mathrm{m}$ which we find ourselves. For this reason, all forms of thought seem to have a built-m bias toward homeostasis even though, up close, they are best understood as dynamic patterns of interaction and reformulation. Overall, the system tends toward equilibrium; the homeostatic tendency is manifested in a sort of dynamic balance. ${ }^{34}$

Legal meaning is possible because of the temporary stability of context that is achieved through these cognitive and social processes. Legal rules seem to work relatively unproblematically only to the extent that "the context is so established, so deeply assumed, that it is invisible to the observer."35 Within a legal/cultural commumity or subculture that shares the same contextual, non-neutral assumptions, a systein of ineaning like constitutional law will work. Moreover, such a system will work in a seemly neutral and unpolitical way precisely because it operates unreflectively, without conscious attention to the assumptions that undergird its meaning. ${ }^{36}$

Within these stabilized matrices, the epistemic and the political are already mutually entailed in a mamier that is likely to be miperceptible to the participant. Judges, no less than others, are situated in and dependent upon the structures of social meaning that make communication possible. ${ }^{37}$ Although this situatedness will not yield anything hike deter-

33. See K. WhITESIDE, supra note 16, at 98 (in his existential theory, Merleau-Ponty "shows that what we accept as reasonable in our personal lives and in our politics is a cultural product, the result of innumerable concrete experiences and accidents that, froin today's point of view, may appear unreasonable"); Winter, The Cognitive Dimension, supra note 12, at 2244-45, $2254 \mathrm{nn} .99-100$.

34. Cf. M. TuSHNET, supra note 3 , at 57 (noting the cohesive "pressures exerted by a highly developed, deeply entrenclied, homeostatic social structure"). In using terms like "homeostasis" and "dynamic balance," I am trying to capture the sense of a cyclical process in which a stabilized context is constantly disturbed, suffers imbalance, and then "rights" itself. I do not mean to suggest, lowever, that the resulting equilibrium will always be the same-as I discuss at infra text accompanying notes 40-42, 129-32, and 135-58.

35. S. Fish, Consequences, in Doing What Comes Naturally, supra note 13, at 320-21.

36. Winter, The Cognitive Dimension, supra note 12, at 2258-60; see also Winter, Upside/Down View, supra note 20; cf. S. Fish, Critical Self-Consciousness, Or Can We Know What We Are Doing, in Doing What Comes Naturally, supro note 13, at 465-67.

37. Winter, The Cognitive Dimension, supra note 12, at 2255-56. 
minacy, ${ }^{38}$ the stabilized matrices within which the judges operate will have already demarcated the arguments and counterarguments they will recognize as persuasive. ${ }^{39}$ And this means that, in a conservative era, the stabilized matrix will already be largely secure from penetration by the very arguments and positions that those on the hiberal-to-left of the pohtical spectrum would want to urge on the Court. Hence, the quandary of constitutional theory in a conservative era.

What I have described as a "stabilized matrix" is, in effect, Thoinas Kuhn's concept of a "paradigm" or "disciplinary inatrix" that makes possible the concrete puzzle-solving that is "normal science." 40 Kuhn's influential account of the history of science identifies rationality as dependent upon such paradigms and describes scientific progress as a cycle of normalization, crisis, and paradigm shift. In a previous essay, I used Alasdair MacIntyre's extension of Kuhn's account ${ }^{41}$ as a model with which to exphicate developments in the legal tradition. ${ }^{42}$ In the section that follows, I further elaborate this model in an account of the development of inodern constitutional law. I then examine soine of the lessons that those of us who would write, teach, and practice constitutional law and theory in a conservative era might draw from this account.

38. See infra text accompanying notes 259-61.

39. See S. Fish, Anti-Professionalism, in Dong What COMES NATURALlY, supra note 13, at 230 ("the institutional space... defines both the present shape of things and the possible courses of action by which that shape might be altered"); see also infra text accompanying notes 279-83.

Because the concept of incommensurability plays such a large role in the argument, it is important to be clear what I mean by this. It is not a claim of total imcommensurability or imcomprehensibility. Cf. D. DAvIDson, On the Very Idea of a Conceptual Scheme, in INQUIRIES INTO TRUTH AND INTERPRETATION 185-86 (1984) (arguing that complete failure of ability to translate makes no seuse). Within any given stabilized matrix, there will be intelligible counterargunents that are not persuasive. In that case, it will be possible to challenge the dominant position without seeming to violate the rules of the game. It ean nevertheless be predicted that the challenge will be unsuccessful.

This will occur, for example, when a conception that is central to one view is relcvant but peripheral to the other. Richard Sherwin suggests that just such a paradigm-dependent dispute occurred in Oregon v. Elstad, 470 U.S. 298 (1985) (prior illegally obtained confession does not taint subsequent, pest-Miranda confession).

[W] hat appears to the majority as a "speculative" thcory of human behavior appears to the

dissenters as plain common sense. Conversely, the "fact" that an imitial uncoerced statement cannot "taint" a later, freely made one appears to the dissenters as "pseudoscientific" analysis, but is to the majority a plainly empirical observation.

Sherwin, Dialects and Dominance: $A$ Study of Rhetorical Fields in the Law of Confessions, 136 U. PA. L. REV. 729, 814 (1988). If, however, the dissenters' conception is so different that it is not even peripheral to the majority's view, then we are likely to find the majority asserting that the dissent's "thcory is out of touch with reality." Pennhurst State School \& Hosp. v. Halderman, 465 U.S. 89, 107 (1984) (characterizing Justice Stevens' invocation of the ultra vires concept of Ex parte Young and its progeny). In either of these cases, we have a partial incommensurability that is sufficient to render the hiberal view functionally irrelevant to the dommant, conservative paradigm.

40. T. KuHN, supra note 15 , at 23-24, 181-87.

41. A. MACINTYRE, WhOSE JUSTICE? Which RATIONALITY? 354-65 (1988).

42. Wimter, Bull Durham, supra note 12, at 671, 679-81 (arguing that the legal academy is currently in the kind of epistemological crisis that typically presages a paradigm shift). 


\section{III}

\section{The Lessons of Constitutional LaW in THe Modern} AGE

\section{A. The Legal Realist Precedent}

The probleins of a progressive constitutional jurisprudence in a conservative era were faced by the legal realists and their New Deal allies. Not surprisingly, many on the left have exphicitly einbraced the legal realists as intellectual forebears. ${ }^{43}$ Mark Tushnet, for example, has declared that "Legal Realisin has a natural home in constitutional law scholarship, where its tendency to reduce law to politics has enormous persuasive power these days." 44

For those who recognize the situatedness of meaning, nothing could be inore appropriate than the turn to history and the self-conscious study of intellectual antecedents. Indeed, in this case, the parallels are powerful and instructive - if not necessarily what they are made out to be. In my view, the parallels tend to be obscured by tendentious readings that reduce both legal realisin and critical legal studies to a simple instrumentalisin. ${ }^{45}$ But, as the realists were fond of pointing out, there are always multiple ways to construe any precedent. ${ }^{46}$ Because all ineaning is meaning in a context, the persuasiveness of the analogy to legal realism will depend on how one frames their similarities and differences.

To test whether the inferences hold-the identification of legal realisin with current left scholarship and the conclusion that both reduce to instruinentalisin-we must consider more fully the respective contexts of these scholarly efforts. To see whether there is a meaningful analogy between their situation and our own, we must situate the legal realists in their historical context and consider the constitutional law developinents in which they participated.

43. See, e.g., Kennedy, Form and Substance in Private Law Adjudication, 89 HARV. L. REV. 1685, 1732 n.108 (1976) (citing a number of legal realists); Tushnet, Critical Legal Studies: An Introduction to Its Origins and Underpinnings, 36 J. LEGAL EDuc. 505, 506-07 (1986) ("The general point of both [CLS and the Legal Realist] traditions was to emphasize the importance of relations of power in the einployment and development of law ...."); Fischl, Some Realism About Critical Legal Studies, 41 U. Miami L. ReV. 505, 524 (1987) (noting that both CLS and the Legal Realists combime "a progressive pohtical critique with a skeptical jurisprudence").

44. Tushnet, supra note 3 , at 543.

45. Ronald Dworkin and Philip Bobbitt have adopted this mischaracterization. See R. DWORKIN, supra note 4, at 151-53, $271-72$ (identifying "pragmatism" with legal realism and critieal legal studies as an heir to legal realisin); Bobbitt, Is Law Politics? (Review Essay), 41 STAN. L. REv. 1233 (1989) (characterizing Tushnet's approach as "prudentialist"). But see Binder, Beyond Criticism, 55 U. CHI. L. REV. 888 (1988) (applying the indeterminacy critique to instrumentalism).

46. See, e.g., K. Llewellyn, The BRAMBle Bush: ON OUR LAW ANd ITs STUdy 66-69 (2d ed. 1951) (heremafter K. LlewellyN, The BRAMble BuSH]; K. LleWeliyN, The CommoN LAW TRADITION: Deciding Appeals 75-91 (1960) [hereinafter K. LLEWELLYN, THE COMMON LAW TRADITION]. 
The loose association known as legal realism was first and foremost a movement of legal scholars and teachers. Legal realism was part of the response to formalism. ${ }^{47}$ Its battles were fought in the halls and journals of legal academia, and its major encounters were over the nature of legal scholarship and the purposes, methods, and curricula of a law school. ${ }^{48}$ These were not accidental engagements, but a logical consequence of the nemesis against which they rebelled. For, to a large degree, formalism was itself a product of changes in legal education and scholarship imitiated during Langdell's stewardship at Harvard. ${ }^{49}$ Langdell's miportance had three related dimensions. At the theoretical level, he espoused the purely logical or conceptual approach to law as a "science" that could be deduced from a few basic primciples manifested in legal doctrimes contained in appellate decisions. At the educational level, he initiated the case method that still dominates much of legal education. At the scholarly level, his theoretical approach recominended systematization of a mass of decisional material into properly classified doctrimes and basic primciples. ${ }^{50}$

These three developments made possible both the university law school and the professionalization of the modern bar. ${ }^{51}$ The reduction of law to concepts rendered apprenticeship obsolete as a means of preparation for legal practice, diminishing the sense of law as a practice that takes place in a particular community and replacing it with an abstract general method. The identification of legal doctrimes contained in books as the proper subject matter of legal study made it respectable to include the law school in a university. The case method made large class imstruction possible. The systematic approach to scholarship beeame a mechamism for the normalization and further dissemination of a standardized

47. W. Twining, Kari Llewellyn and the Realist Movement 10 (1973) ("Iegal realism was in the first instance a reaction against an approach to law that was characterized as 'formalism' "); E. Purceli, JR., The CRisis of Democratic TheORY: ScienTific Naturalism \& THE Problem of Value 74-77 (1973) (discussing formalism and the reactions to it).

48. See W. TwINING, supra note 47 , at $42-55$ (describing the curricular and deanship controversies at Columbia Law School in the 1920s); E. PURCELI, JR., supra note 47, at 77-78 (legal realism was a reaction to the professionalization of law teaching).

49. W. TwiniNg, supra note 47, at 10 (For critics like Holmes and Frank, "Langdell quite explicitly symbolized 'the enemy.' "); G. GILMORE, THE DEATH OF CONTRACT 59 (1974) ("What the realists had principally attacked, savagely and successfully, was the essentially Langdellian idea that cases can be arranged to make sense-indeed scientific sense."); Siuger, Legal Realism Now (Review Essay), 76 CALIF. L. REV. 465, 469 (1988) ("[T] he realists rebelled, to some extent, against Langdell's case method."); Grey, Langdell's Orthodoxy, 45 U. PrTT. L. REv. 1, 3-4 (1983) (Langdell's "classical orthodoxy is the thesis to which modern legal thought has been the antithesis").

50. W. TwinING, supra note 47 , at 11-14.

51. G. GILMORE, supra note 49, at 97-98; see also Fischl, supra note 43, at 511 (discussing the "causes" of "scientific jurisprudence"). Morty Horwitz traces the roots of this phenomenon to changes during the 1820 s and 1830 s that were increasingly entrenched by mid-ceutury. $M$. HoRwitz, The TRANSFormation OF AMERICAN LAW, 1780-1860, at 256-66 (1977). 
version of the law. ${ }^{52}$ All together, these developments made possible the stabilization of law as a "normal science." 53

Beginning with Holmes, Pound in his early days, Corbin, and Cook, . the realists and their predecessors opposed the formalist focus on general concepts and rules as providing a logical or mechanical means for deciding cases. This early opposition was taken further by the later, more radical critiques such as the rule and fact skepticisin of Llewellyn ${ }^{54}$ and Frank. ${ }^{55}$ But these critiques did not amount to a general claim of indeterminacy, except perhaps in the hands of those later adversaries who charged the realists with nihilism. ${ }^{56}$ To the contrary, the legal realists beheved that inquiry into empirical and social facts could provide a basis for reforming law and reformulating legal practice. ${ }^{57}$

52. See W. Twining, supra note 47 , at 14 :

Between 1886 and 1920 Harvard scholars, notably Williston, Beale, Gray and Thayer, took the lead in writing a series of monumental legal treatises which won immediate recognition among practitioners as well as among legal seholars at home and abroad. ... The assumptions and attitudes underlying these treatises bore a close affinity to Langdell's conception of law.

Langdell himself participated in this phenomenon both in the publication of his casebook on contract, C. Langdell, A Selection of Cases on the Law of Contracts (1879), and his attempt to systematize equity jurisprudence in a series of articles with the ironic title $A$ Brief Survey of Equity Jurisdiction. Langdell, A Brief Survey of Equity Jurisdiction, (pts. 1-8), 1 HARV. L. REv. 55 (1887), 1 HARV. L. Rev. 111 (1887), 1 HARV. L. Rev. 355 (1888), 2 HARV. L. ReV. 241 (1889), 3 HARV. L. ReV. 237 (1890), 4 HARV. L. ReV. 99 (1890), 5 HARV. L. REV. 101 (1891), 10 HARV. L. ReV. 71 (1896); see also Langdell, Classification of Rights and Wrongs, (pts. 1 \& 2), 13 HARV. L. REv. 537, 659 (1900).

53. For Kuhn, normal science depends upon the development of stable scientific communities in which all community inembers "have undergone similar educations and professional initiations; in the process they have absorbed the same technical literature and drawn many of the same lessons from it." T. KuHN, supra note 15, at 177; see also id. at 164-66 (role of professional education and standardized textbooks in maintaining a scientific community and its paradignis).

54. See, e.g., K. LleWEllyN, THE BRAMBLe Bush, supra note 46, at 12 ("Wc liave discovered that rules alone, mere forms of words, are worthless."); id. at 61 ("Your application of a rule of law bears then on what you have already decided to be the meaning of the facts. It does not touch the raw evidence at all.").

55. J. FRANK, LAW AND THE MODERN MIND 129 (1930) ("There never was and there never will be a body of fixed and predetermined rules alike for all... Life rebels against all efforts at legal over-simplification."); id. at 125 ("[The judge's] general liunch ... a affects his report-both to limself and to the public-concerning the facts. Only a superficial thinker will assume that the facts as they occurred and as they later appear to the judge (and as le reports them) will invariably -or indeed often-correspond.").

56. Although his sociological jurisprudence was a forerunner of legal realism, Roscoe Pound was in later life aunongst realism's most outspoken opponents. See, e.g., 1 R. Pound, JURISPRUDENCE 271 (1959) ("There is a more or less complete skepticism as to the systematic character of official action as a quality of the legal order ...."); E. PURCELL, JR., supra note 47, at 159-69 ("While Pound had been one of the critics of legal realism, his comments had retained a certain balance ... . During the late thirties, however, he grew increasingly lostile.").

57. See E. PURCELL, JR., supra note 47 , at $86-87$ ("The realists were especially sympathetic to the new social science because they shared many of its assumptions."); Fischl, supra note 43, at 520 21 ("To overstate the matter somewhat, the Realists sought to substitute one form of science for another."); Peller, The Metaphysics of American Law, 73 CALIF. L. REv. 1151, 1240-50 (1985) ("This conception of the significant methodologieal aspect of realist jurisprudence-that it 'reverses, 
This strand of realism dated back to Holmes, who observed, "For the rational study of the law the black-letter man may be the man of the present, but the man of the future is the man of statistics and the master of economics." 58 Corbin, Hohfeld, and Cook, some of the early scholars associated with legal realism, each had training in the natural sciences before turning to law. ${ }^{59}$ Even the later, more radical realists kept faith with some form of scientific or empirical naturalism. Llewellyn's preference for merchant practice as a basis for contractual rules is a wellknown and well-documented example; ${ }^{60}$ in other areas, he advocated rehiance on the unreflexive, experientially and culturally grounded reason that he referred to as "situation-sense"61 and "horse sense."62 Felix Cohen's famous attack on formalist reasoning as "transcendental nonsense" concluded with the assertion that:

Legal criticism is empty without objective description of the causes and consequences of legal decisions. ... It is through the union of objective legal science and a critical theory of social values that our understanding of the hunian significance of law will be enriched. ${ }^{63}$

Even Jerome Frank, whom many think of as the most radically skeptical of the realists, beheved in the explanatory power of psychoanalytic theory. ${ }^{64}$ Indeed, none of these approaches simply reduced law to pohitics.

Moreover, the legal realists rarely addressed constitutional law in an explicit or direct manner. ${ }^{65}$ For the most part, the legal realists focused

it upsets the whole traditional approach to law'. . - -was shared by other realists.") (quoting Llewellyn, A Realistic Jurisprudence-The Next Step, 30 Colum. L. Rev. 431, 443 (1930)).

58. Holmes, The Path of the Law, 10 HARv. L. REv. 457, 469 (1897).

59. W. TWINING, supra note 47, at 27 (Corbin studied biology, anatomy, and chemistry as an undergraduate); id. at 36-37 (Hohfeld studied chemistry); id. at 37 (Cook had graduate training in inathematics and physics).

60. See, eg., id. at 224-25, 306-07.

61. K. Llewellyn, The Common Law Tradition, supra note 46, at 60-61. For an explanation of Karl Llewellyn's concept of "situation-sense" as anticipating recent developments in cognitive theory, see Winter, The Cognitive Dimension, supra note 12, at 2262-67.

62. By "horse sense," Llewellyn meant "the balanced shrewdness of the expert in the art." $\mathrm{K}$. LleWellyn, THE COMmON LAW TRADITION, supra note 46, at 121.

63. Cohen, Transcendental Nonsense and the Functional Approach, 35 Colum. L. REv. 809, 849 (1935). For an extension of Cohen's concept of "relativity's laws" and how they operate in constitutional doctrine, see Winter, Transcendental Nonsense, supra note 12, at 1170-71, 1193-95.

64. See J. Frank, supra note 55, at 19-21, 98.

65. Two (largely forgotten) exceptions are Thomas Reed Powell and Karl Llewellyn. Powell, The Judiciality of Minimum-Wage Legislation, 37 HARv. L. REv. 545 (1924), discussed at infra note 87; Llewellyn, The Constitution As an Institution, 34 CoLUM L. REv. 1 (1934), discussed at infra text accoinpanying notes $86-89,254-59$ \& 364-66.

Llewellyn's realist accoant of constitutional law is rarely cited. Powell's work, however, is occasionally cited in contemporary constitutional law scholarship. See, eg., G. STONE, L. SEIDMAN, C. SUNSTEIN \& M. TUShNET, supra note 11, at 740; Keunedy, supra note 43, at 1757 n.141. 
on areas such as contracts, ${ }^{66}$ property, ${ }^{67}$ business law, ${ }^{68}$ and conflicts. ${ }^{69}$ Some of this work did have constitutional overtones, of course, as we shall see shortly. ${ }^{70}$ But the inost infiuential conteinporary progressive constitutional law scholars, people like Felix Frankfurter and James Landis at Harvard, were not considered realists by Llewellyn. ${ }^{71}$

The intersection between legal realisin and constitutional law was coinplex, and soinewhat oblique. It had less to do with the substantive positions of the realists than with the Court's formalist approach to both constitutional and private law. In its economic substantive due process decisions, the Court's twofold einbrace of formalisin allowed it "to equate the 'liberty' secured by the due process clause . . . with the 'free

66. See, e.g., Corbin, Third Parties As Beneficiaries of Contractors' Surety Bonds, 38 YALE L.J. 1 (1928); Llewellyn, What Price Contract?-An Essay in Perspective, 40 YALE L.J. 704 (1931); Oliphant, Mutuality of Obligation in Bilateral Contracts at Law, 25 ColuM. L. REV. 705 (1925).

67. See, e.g., Colien, Property and Sovereignty, 13 CoRnel. L.Q. 8 (1927). Robert Hale's work challenged the underlying theoretical assumptions of both contract and property law. See Hale, Bargaining, Duress, and Economic Liberty, 43 ColuM. L. Rev. 603 (1943); Hale, Coercion and Distribution in a Supposedly Non-Coercive State, 38 PoL. Scr. Q. 470 (1923).

68. See, e.g., Clark, Douglas \& Thomas, The Business Failures Project-A Problem in Methodology, 39 YALE L.J. 1013 (1930); Moore \& Hope, An Institutional Approach to the Law of Commercial Banking, 38 YALE L.J. 703 (1929); Oliphant, Trade Associations and the Law, 26 COLUM. L. REV. 381 (1925).

69. See, e.g., Cook, The Logical and Legal Bases of the Confiict of Laws, 33 YALE L.J. 457 (1924); Yntema, The Hornbook Method and the Confiict of Laws, 37 YALE L.J. 468 (1928).

70. See infra text accoinpanying notes 82-83 \& 117-18.

71. See Llewellyn, Some Realism About Realism, 44 HARv. L. Rev. 1222, 1227 n.18 (1931) [hereinafter Llewellyn, Some Realism] (referring to Frankfurter as a "sociological jurist," not a realist). This article was Llewellyn's response to Pound, The Call for a Realist Jurisprudence, 44 HARV. L. REV. 697 (1931). When Llewellyn first compiled his list of realists in preparing his response, he characterized Frankfurter and Landis as "realists-im-part-of-their-work." He did not, lowever, include them in his final version. Hull, Some Realism About the Lleweliyn-Pound Exchange Over Realism: The Newly Uncovered Private Correspondence, 1927-1931, 1987 WIS. L. REv. 921, 959-60; $c$. Llewellyn, A Realistic Jurisprudence-The Next Step, 30 CoLUM. L. REV. 431, 454 n.22 (1930) (earlier classification of Frankfurter's work with Landis and with Greene as "realistic").

Legal historians lave recently questioned Llewellyn's exclusion of Frankfurter and Landis from his final list. In forthcoming work, Morty Horwitz argues that our perceptions of legal rcalism have unfortunately been skewed by the partiality of Llewellyn's list. See also Hull, supra, at 964 (arguimg that the more inclusive list provides a fuller picture of the realist movement); see also Hull, Reconstructing the Origins of Realistic Jurisprudence: A Prequel to the Llewellyn-Pound Exchange Over Legal Realism, 1989 DUkE L.J. 1302 (detailing the influence of Pound on Llewellyn and the reasons for the break between them).

Nevertheless, it is difficult to think of Justice Frankfurter as a legal realist when one considers his response to Erie Railroad v. Toinpkins, 304 U.S. 64 (1938). In a letter to President Roosevelt two days after the decision, Frankfurter wrote: "I certainly didn't expect to live to see the day when the Court would announce, as they did on Monday, that it itself had usurped power for nearly a liundred years. . . . How fiuid it all makes the Constitutionl" C. WRIGHT, THE LAw OF FEDERAL CourTs 355 n.12 (4th ed. 1983) (citing M. FreEDMAN, RoOSEVELT AND FRANkFURTER 456 (1967)). 
will' from which they believed they could deduce the common law rules."72

But the economic substantive due process decisions were also formalist in the more fundamental sense that they assumed the acontextuality of meaning. The concepts that they invoked-like "liberty of person and freedom of contract"73 - were treated as imvariable regardless of context. ${ }^{74}$ Thus, in cases like Lochner $v$. New York ${ }^{75}$ and Coppage $v$. Kansas, ${ }^{76}$ the Court not only began with a principle from which to deduce its conclusions, but also assumed that the meanings of "freedorn" and "contract" remain constant across changing circumstances. ${ }^{77}$ It therefore could see no relevant difference between the contracts of a corporation and its non-umionized workers, on one hand, and the prototypical arm's length bargain of free moral agents, on the other. ${ }^{78}$ For the fornalist Court of the Lochner era, reasoning within the stabilized matrices that gave meaning to these concepts, the pohtical and the epistemic were already mutually entailed in a way that could seem ouly "neutral" and "objective."79 As such, the Court could unabashedly declare that disparities of wealth were earned and legitimate. ${ }^{80}$ Disparities of wealth could no more make freedoin "coercive" than a monopoly over production could turn manufacturing into "commerce."

72. Kennedy, supra note 43, at 1754 . Kennedy continued, "This bold stroke integrated public and private law." Id.

73. Lochner v. New York, 198 U.S. 45, 57 (1905).

74. But cf. West Coast Hotel v. Parrisl, 300 U.S. 379, 391 (1937) (asking what "freedom of contract" is and noting that "Liberty in each of its phases has its history and connotation."), discussed at infra text accompanying notes 425-42.

75. 198 U.S. 45 (1905).

76. 236 U.S. 1 (1915).

77. See Singer, supra note 49, at 499 ("Roscoe Pound called formalisin 'mechanical jurisprudence' because the classical lawyers had a tendency to apply their general principles relentlessly-regardless of the underlying policies or the consequences of these policies in specific cases.").

78. The act ... is an illegal interference with the rights of individuals, both employers and einployés, to inake contracts regarding labor upon such terms as they may think best, or which they may agree upon with the other parties to such contracts. Statutes of the nature of that under review, limiting the hours in which grown and intelligent unen may labor to earn their living, are mere ineddlesoine interferences ....

Lochner, 198 U.S. at 61.

79. These "stabilized matrices" correspond to what Cass Sunstein calls a "baseline" or "Lochner-like premise." Sunstein, supra note 9, at 882-83. The shortcomings of Sunstein's "baseline" inetaphor are explored in Winter, Upside/Down View, supra note 20, at n.2.

80. See Coppage, 236 U.S. at 17-18 (It is "impossible to uphold freedom of contract and the right of private property without at the same time recognizing as legitimate those inequalities of fortune that are the necessary result of the exercise of those rights.").

81. See United States v. E.C. Knight Co., 156 U.S. 1, 17 (1895) (" [I]t does not follow that an attempt to inonopolize, or the actual inonopoly of, the manufacture was an attempt, whether executory or consummated, to monopolize commerce, even though, in order to dispose of the product, the instrumentality of commerce was necessarily invoked."); Kidd v. Pearson, 128 U.S. 1 (1888) (asserting that manufacturing is not commerce). 
It is thus not surprising that the constitutional progressives would draw upon some of the antiformalist ideas and strategies of the legal realists. ${ }^{82}$ To the extent that the realists sought to "replace formalistic deduction of consequences from abstract concepts with explicit policy, moral, and institutional analysis," tutional progressives. But the overlap between the constitutioual progressives and the legal realists was far froin complete.

The constitutional progressives were reacting to judicial interference with progressive legislative initiatives. What they wanted was less judicial discretion and creativity, not nore. The legal realists, on the other hand, stressed that law was an ongoing judicial creation. ${ }^{84}$ Felix Colren, for example, favored a judicial decision on the basis of "such economic, sociological, political, or ethical questions as a competent legislature might have faced."85 So too, Llewellyn's quite radical approach to constitutional law pressed for recognition of "the fact of creation by the Court" and argued that "[o]nce such creation is recognized and the implications of the recognition fairly faced, there is no stopping short."

Indeed, Llewellyn did not stop short. Breaking with the progressive wisdoin about Lochner-era cases like Coppage, he proclaimed:

[T] here is no quarrel to be had with judges merely because they disregard or twist Documentary language, or "interpret" it to the despair of original intent, in the service of what those judges conceive to be the inherent nature of our institutions. To my mind, such action is their duty. . . I I may feel, say in the Coppage and Abrams and Adkins Cases, that [they were] quite misguided. But I cannot simultaneously defend the dissents in those cases and deny the implicit premise cominon to majority and dissent ....

The ... point is therefore, obviously, that a sane theory of constitutional law would no more be a substitute for adequate personnel than is the prevalent modified and halfway reworking of the ancient orthodoxy. The only guarantee of judicial wisdom will remain the judge. ${ }^{87}$

82. Conversely, it is not surprising that the realists celebrated and built a program out of the insights of older antiformalists like Holmes. Perhaps the inost famous example of Holmes' antiformalism is his observation in Lochner that "General propositions do not decide concrete cases." 198 U.S. at 76 (Holmes, J., dissenting).

83. Singer, supra note 49 , at 471 .

84. See, eg., Llewellyn, Some Realism, supra note 71 , at 1236.

85. Cohen, supra note 63 , at 810 .

86. Llewellyn, supra note 65 , at $4 \mathrm{n} .8$ (emphasis in original).

87. Id. at 33-34 (emphasis in original). Thomas Reed Powell's position was no less uncompromising. See Powell, supra note 65 , at 573 (" $[\mathrm{I}] \mathrm{n}$ explaining the determination of constitutional issues we must take account of the temper, as well as the outlook, of the judges before whoin the issues chance to coine.").

These quotes demonstrate a problem with Duncan Kennedy's blanket statement that this period's "altruists" abdicated the more radical option of "accepting the analogy of private and public law, and then arguing that both were inherently 'political,' in the sense of requiring the judge to make choices between the rival social visions of individualism and altruism." Kennedy, supra note 
Llewellyn's solutions to the constitutional crisis already under way in 1934 were typically straightforward: He suggested increasing the number of Justices ${ }^{88}$ or requiring a supermajority vote of six, seven, or even eight to invalidate a statuite as unconstitutional. ${ }^{89}$

With the onset of the New Deal, agreement between the realists and the constitutional progressives on political objectives undoubtedly increased. ${ }^{90}$ But the radicalism recommended by the rcalists had little appeal to those pursuing change in constitutional law. Rather, developments in constitutional law were largely dominated by other, more conventional influences.

"In the crucible of events we become aware of what is not acceptable to us, and it is this experience as interpreted that becoines both thesis and philosopliy."91 The "crucible" that sliaped inodern constitutional law was the confrontation between the Old Court and the legislative efforts of, first, the Progressive Era, and then the New Deal. The inost influential manifestos of this conflict were not the legal rcalist assaults on the intellectual foundations of formalism, ${ }^{92}$ but rather tlie decades of dissents by Holmes and Brandeis-tlie "Great Dissenters"-who liad been venerated by progressives and rcalists alike. ${ }^{93}$ These dissents opposed judicial interference witl social and economic legislation. But they also supported judicial protection of civil liberties. ${ }^{94}$ When Hughes replaced

43, at 1756 (emphasis in original). To support his characterization, Kennedy cites only to mainstream judicial positions, most notably to opinions by Harlan Fiske Stone. See id. at 1756-58 nn.136-42. Whether Jnstice Stone should be categorized as one of the realists or one of the constitutional progressives is an interesting question. As Dean at Columbia, he had been on the defensive in the debate with the realists over educational reform. See W. TwINING, supra note 47, at 45-46. Early in his tenure on the Court, he sinnultaneously disparaged the circularity of legal doctrines and articulated a strong preference for deference to the legislature. See, e.g., Tyson \& Brother v. Banton, 273 U.S. 418, 451 (1927) ("It is difficult to use the phrase ['affected with a public interest'] free of its comiotation of legal consequences, and hence when used as a basis of judicial decision, to avoid begging the question to be decided."); id. at 454 ("Choice between these views takes us from the judicial to the legislative field.").

88. Llewellyn, supra note 65 , at 23 n.33, 39 n.45.

89. Id. at 36 \& n.42.

90. E. PURCELL, JR., supra note 47, at 93 ('Frank, Ohiphant, Clark, Arnold, Douglas, and Felix Cohen all became ardent New Dealers"); W. TwINING, supra note 47, at 57-58, 68 (Frankfurter, Berle, Arnold, and Douglas served im New Deal administration); Biography of Felix $S$. Cohen, 9 Rutgers L. REv. 345, 347-49 (1954) (Felix Cohen worked on behalf of Native Americans in Interior Department).

91. M. MERLEAU-PoNTY, Dialectic, supra note 1 , at 3.

92. See generally Kennedy, supra note 43, at 1748-60.

93. In 1975, Herbert Wechsler told my constitutional law class that, as a student at Columbia in the late 1920s, he and his classmates treated the latest Holmes and Brandeis dissents as virtually sacred texts to be read and studied. The legal realists shared this veneration of Holmes. See, e.g., J. Frank, supra note 55, at 270-77; Llewellyn, Holmes, 35 ColUM. L. REv. 485 (1935).

94. See, e.g., Whitney v. Califomia, 274 U.S. 357, 372 (1927) (Brandeis, J., concurring); Gitlow v. New York, 268 U.S. 652, 672 (1925) (Holmes, J., dissenting); Abrams v. Urited States, 250 U.S. 616, 624 (1919) (Holmes, J., dissenting).

For Holmes, unlike his successors, the different judicial stances in economic and free speech 
Taft as Chief Justice in 1930, the Court pushed forward with these pioneering efforts. ${ }^{95}$ By 1937, when the paradigm shift took place, ${ }^{96}$ the constitutional philosophy that einerged was shaped by the very practices that the constitutional progressives had opposed. ${ }^{97}$ Indeed, the new constitutional paradigm was a virtual mirror image of the Old Court's jurisprudence: judicial deference in areas of economic regulation ${ }^{98}$ and judicial proteetion of civil rights and hberties. ${ }^{99}$ It is thus not surprising

matters were sustained by a single philosophical underpinning: a thoroughly relativist view of truth. Cf. Abrams, 250 U.S. at 630 (Holmes, J., dissenting) ("[T]he best test of truth is the power of the thought to get itself accepted in the competition of the market . . . ."); Lochner v. New York, 198 U.S. 45, 75-76 (1905) (Holmes, J., dissenting) (defending "the right of a majority to embody their opinions in law" and arguing that "the word liberty in the Fourteenth Amendment is perverted when it is held to prevent the natural outcome of a dominant opinion"); see also Winter, Transcendental Nonsense, supra note 12, at 1188-90. This apparently was Hohnes' long-standing view. See Holmes, Natural Law, 32 HARv. L. Rev. 40, 40 (1918) ("I used to say, when I was young, that truth was the majority vote of that nation that could hick all others.").

95. See, eg., Near v. Minnesota, 283 U.S. 697, 716 (1931) (declaring state infringement on freedom of the press unconstitutional); Stromberg v. California, 283 U.S. 359, 369-70 (1931) (holding unconstitutional a state statute making it illegal to display a red flag in public).

96. The year 1937 is widely recognized as a watershed, reflecting a major shift in the legal/ social consensus on the constitutional status of the New Deal's regulatory programs. See, e.8., B. ACKERMAN, ReCONSTRUCTING AMERICAN LAW 6-11 (1984); Ackerman, Storrs Lectures, supra note 5, at 1053-57; Cohen, Field Theory and Judicial Logic, 59 YALE L.J. 238, 248-49 (1950); Micliehnan, Law's Republie, 97 YALE L.J. 1493, 1522 n.112 (1988). The decisions that inanifested this paradigm shift in constitutional law were West Coast Hotel v. Parrish, 300 U.S. 379 (1937) (due process), and NLRB v. Jones \& Laughlin Steel Corp., 301 U.S. 1 (1937) (commerce clause). But the shift manifested itself in other areas as well. A similar upleaval in federal civil procedure occurred in 1938 with the decision in Erie Railroad v. Tompkins, 304 U.S. 64 (1938), and the adoption of the Federal Rules of Civil Procedure. Tribe, The Curvature of Constitutional Space: What Lawyers Can Learn From Modern Physics, 103 HARv. L. ReV. 1, 25 (1989); see also Sunstein, supra note 9, at 881-82; infra text accompanying notes 400-08.

97. See Chemerinsky, The Supreme Court, 1988 Term-Foreword: The Vanishing Constitution, 103 HaRV. L. REV. 43 (1989).

In the 1930's, econoinic pressures from the Depression, political opposition by the Roosevelt Administration, and intellectual assaults by the Legal Realists highlighted the anti-majoritarian character of judicial review. The Supreme Court's invalidation of popular New Deal legislation made it especially vulnerable to such criticisms. By the late 1930 's, the new Justices lad to define a role for the judiciary that did not offend their earlier criticisms of the Lochner era Court. This was not siniply a matter of appearance or strategy; a strong consensus existed that the previous Court had acted improperly in striking down needed social and economic legislation. In fact, since the mid-1930's, discussions about constitutional law lave been dommated by a desire to devise a role for the Supreme Court that avoids the evil of Lochnerism.

Id. at 63 (citations oinitted).

98. See, eg., United States v. Carolene Prods. Co., 304 U.S. 144 (1938); West Coast Hotel v. Parrish, 300 U.S. 379 (1937).

99. See De Jonge v. Oregon, 299 U.S. 353 (1937) (first amendinent invalidates criminal prosecution for attending peaceful meeting); Herndon v. Lowry, 301 U.S. 242 (1937) (same); Lovell v. City of Griffin, 303 U.S. 444 (1938) (city ordinance prohibiting distribution of literature without discretionary permit from mayor held unconstitutional); Missouri ex rel. Gaimes v. Canada, 305 U.S. 337 (1938) (Constitution requires admission of blacks to state law school); Hague v. CIO, 307 U.S. 496 (1939) (striking down permit provision used to prohibit union activities on public streets and in public meeting halls); Schneider v. State, 308 U.S. 147 (1939) (handbilling ban unconstitutional); Thornhill v. Alabama, 310 U.S. 88 (1940) (statute banning all picketing unconstitutional); Cantwell 
that the only early twentieth-century substantive due process decisions which survive as precedents are Meyer v. Nebraska ${ }^{100}$ and Pierce $v$. Society of Sisters. ${ }^{101}$

What emanated from this shift looked less like a considered philosophical program than "a relatively sudden and unstructured event like the ges[t]alt switch."102 The emergent justification for this new paradigm first appeared in footnote four of Carolene Products. ${ }^{103}$ The appearance of such a major "philosophical" statement as dictum in a footnote-as well as its very tentative language ${ }^{104}$ - underscores how exploratory. and hesitant the new thesis really was. ${ }^{105}$ And there was reason for it to be: The constitutional jurisprudence of footnote four and most of the rest of this period was premised on an idealized-indeed, hopelessly romanticized-view of the majoritarian political process. ${ }^{106}$ Moreover, the footnote four prescription for the post-Lochner, post-formalist period was neither self-evident nor uncontested. Some of the constitutional progres-

v. Connecticut, 310 U.S. 296 (1940) (ban on Jehovah's Witnesses' door-to-door ministry unconstitutional); Mitchell v. United States, 313 U.S. 80 (1941) (requiring intcgrated sleeping cars on interstate train); Martin v. City of Struthers, 319 U.S. 141 (1943) (ban on door-to-door speech unconstitutional); West Virginia State Bd. of Educ. v. Barnette, 319 U.S. 624 (1943) (compulsory flag salute nnconstitntional); Schneidernan v. United States, 320 U.S. 118 (1943) (restoring revoked citizenship); Marsh v. Alabama, 326 U.S. 501 (1946) (ban on leafletting in coinpany town cannot be enforced by state criminal trespass law); Sipuel v. Board of Regents, 332 U.S. 631 (1948) (admission of blacks to state law school); Takahashi v. Fish \& Game Comm'n, 334 U.S. 410 (1948) (state cannot deny fishing license to resident alien); Saia v. New York, 334 U.S. 558 (1948) (unrestrained discretion in issuing sound amplification equipineut unconstitutional); Terminiello v. Chicago, 337 U.S. 1 (1949) (ordinance prohibiting inciting people to anger unconstitutional); Sweatt v. Painter, 339 U.S. 629 (1950) (separate law school not equal); McLaurin v. Oklahoina State Regents, 339 U.S. 637 (1950) (segregation of graduate student unconstitutional).

100. 262 U.S. 390 (1923).

101. 268 U.S. 510 (1925); see infra text accoinpanying notes 466 \& 516-23.

102. T. KuHN, supra note 15 , at 122 .

103. United States v. Carolene Prods. Co., 304 U.S. 144, 152 n.4 (1938).

104. As Jack Balkin points out, the footnote's three paragraphs begin with the rather diffident phrases: "There inay be narrower scope for . .."; "It is unnecessary to consider now ..."; and "Nor nced we enquire whether . . . " Balkin, The Footnote, 83 Nw. U.L. REv. 275, 284-85 (1989) (quoting Carolene Products, 304 U.S. at 152 n.4).

105. Cf. Cover, The Origins of Judicial Activism in the Protection of Minorities, 91 YALE L.J. 1287, 1316 (1982) ("For, whether or not the [Carolene Products] footnote is a wholly coherent thcory, it captures the constitutional experience of the period from 1954 to 1964 . And that experience, more than the logic of any theory, is the vahdating force in law.").

106. For arguments debunking this romanticized view of niajoritarian politics, see Deutsch, Neutrality, Legitimacy, and the Supreme Court: Some Intersections Between Law and Political Science, 20 STAN. L. REV. 169, 185 (1968) ("Even superficial analysis reveals . . that the contrast between a Court wholly insulated froin the desires of the electorate and a legislature and executive devotedly registering the will of their constituents functions rather as a literary device than as a description of reality."); Balkin, supra note 104, at 299-303 (discussing Carolene Products footnote four as part of the opinion's "governing inyth" behind its pluralist outlook); LaRue, Antitrust and Politics, 33 ANTTTRuST Bull. 745, 749 (1988) ("[W] are a deinocracy in theory, but an oligarchy in practice."); see also Ackernan, Beyond Carolene Products, 98 HARV. L. REV. 713 (1985); Miller, The True Story of Carolene Products, 1987 SuP. Cr. REv. 397. 
sives urged a more consistently deferential jurisprudence that would defer to legislative determinations even when the subject matter was individual rights. ${ }^{107}$

They lost, of course. The footnote four paradigm provided the stabilized context that makes possible both a system of meaning like constitutional law and a normalized legal practice. In this new version of normal science, the empirical, pohicymaking action moved to the legislature; the limited but important sphere of protection of civil rights and biberties was confided to the judiciary. This new paradigm made possible the kind of systematization and concrete puzzle-solving that is the hallmark of normal science: ${ }^{108}$ "The legal academy of the 1950 s was decisively influenced by a way of thinking in which systematic philosophy was put aside in favor of the apphication of sound coinmon sense to concrete legal problems generated by the ordinary operations of the goverument." 109 These efforts reached a theoretical high point in the 1950s, with Hart and Sacks' Legal Process materials, ${ }^{110}$ the first edition of Hart and Wechsler's Federal Courts, ${ }^{111}$ Herbert Wechsler's Neutral Principles, ${ }^{112}$ and Lon Fuller's Forms and Limits of Adjudication. ${ }^{113}$

In one sense, the legal realists were caught flat-footed by this paradigm shift. Not surprisingly, they tempered their views in ways more consonant with a period of normal science. Thus, the 1950 s and 1960 s saw some very substantial moderations by Felix Cohen, ${ }^{114}$ Jerome

107. See, e.g., Minersville School Dist. v. Gobitis, 310 U.S. 586 (1940) (upholding state regulation requiring school children to salute the flag); West Virginia State Bd. of Educ. v. Barnette, 319 U.S. 624, 646 (1943) (Frankfurter, J., dissenting) (dissenting from holding by Court that state action forcing children to salute the flag is unconstitutional); Colegrove v. Green, 328 U.S. 549 (1946) (affirming dismissal of complaint seeking to restrain state officials from acting pursuant to alleged gerrymandering election laws); Saia v. New York, 334 U.S. 558, 562 (1948) (Frankfurter, J., dissenting) (dissenting from holding that city ordinance forbidding unauthorized public use of sound ainplifiers unconstitutional); Kovacs v. Cooper, 336 U.S. 77, 89 (1949) (Frankfurter, J., concurring) (concurring in judgment that city ordinance prohibiting "sound trucks" is constitutional); Baker v. Carr, 369 U.S. 186, 266 (1962) (Frankfurter, J., dissenting) (dissenting froin Court's holding that plaintiff's complaint of denial of equal protection under state election laws presents a justiciable cause of action). By far the inost successful product of this deferential position was the inodern doctrine of standing. See Winter, The Metaphor of Standing, supra note 12, at 1447-57.

108. T. KuHN, supra note 15, at 35-38.

109. Tushnet, supra note 3 , at 548.

110. H. Hart \& A. Sacks, The Legal Process: Basic Problems in the Making and ApPliCATION OF LAW (tent. ed. 1958).

111. H. Hart \& H. Wechsler, The Federal Courts and the Federal System (1st ed. 1953).

112. Wechsler, Toward Neutral Prineiples of Constitutional Law, 73 HARV. L. REV. 1 (1959).

113. Fuller, The Forms and Limits of Adjudication, 92 HARv. L. REv. 353 (1978) (first written and widely circulated in the late 1950s and early 1960s and published only posthumously).

114. Compare Cohen, supra note 96, at 245 ("[T]he real question is not whether judges should follow precedent (or logic or the law of gravitation or anything else that they cannot help following, whether they know it or not). It is, rather, how they should follow precedent . . . .") (emphasis in original; citations omitted) with Cohen, supra note 63, at 810-11 (arguing that formalistic legal 
Frank, ${ }^{115}$ and Karl Llewellyn ${ }^{116}$ of the radical, deconstructive positions they had espoused in the 1930s.

Although I have argued that the legal realists had very hittle influence on the direction of change in constitutional law, it would be wrong to conclude that legal realism was not a participant in the crisis that paved the way for a paradigm shift. To the contrary. During the 1930s, law underwent an intellectual crisis fueled by decades of industrialization and change, ${ }^{117}$ the economic breakdown of the Great Depression, the confrontation between the Old Court and the New Deal, and the continuing affirmation of the latter at the polls. ${ }^{118}$ Legal realism contributed to this crisis by undermining the intellectual foundations of the Old Court's jurisprudence.

Nevertheless, the realists' skeptical critiques were neither the primary cause of the demise of the Old Court's formalism nor the primary contributors to the ideology of the new paradigm. The new paradigm assimilated the legal realists' preference for legislative freedom and administrative decisionmaking, as well as a bastardized, normalized version of legal realism for the courts in the banal form of balancing tests and policy analysis. ${ }^{119}$ Beyond such vague influences, however, the legal realists were unsuccessful in translating their critique into a mainstream legal practice. ${ }^{120}$

reasoning does not account for the real reasons of decision and should be replaced with realistic, empirieal analysis of social fact and pohicy).

115. See J. FraNK, supra note 55, at xx (6th printing 1963) ("I do not understand how any decent man today can refuse to adopt, as the basis of modern civilization, the fundamental principles of Natural Law, relative to human conduct, as stated by Thomas Aqninas.").

116. See K. Llewellyn, The BRAmble Bush, supra note 46 , at 8-10 (qualifying his earlier assertion- "What these officials do about disputes is, to my mind, the law itself"-and decrying the distortion of his position that occurred in the controversy over realisin).

117. See Winter, Bull Durham, supra note 12, at 678-79; see also E. PURCELL, JR., supra note 47, at 79:

The state of American law invited and even necessitated the devastating attacks of the realists. The inconsistencies between the practices of a rapidly changing industrial nation and the claims of a inechanieal juristic system had grown so acute by the 1920 s that, in the minds of many, the orthodox jurisprudence could no longer justify and explain contemporary practice.

118. See Ackerman, Storrs Lectures, supra note 5, at 1053-57; see also Ackerman, Constitutional Politics, supra note 5, at 510-15.

119. The Realists' constructive program provides the framework for inost legal thought today. One need only read a randomly selected law review article or . . . a randomly selected student note or comment to find that the right answer to the question at issue can be found by balancing the interests identified in the appropriate three-part [balancing] test. Tushnet, supra note 43, at 507; see also Fischl, supra note 43, at 522 ("The principal legacy of Legal Realisin for inainstream legal thought is the introduction of 'social policy' analysis . . . albeit in a form that bears precious hittle resemblance to the far subtler version that the Realists seemed to have had in unind.") (citations omitted); Singer, supra note 49, at 504 ("The realists were extremely successful at introducing interest balancing, line-drawing, pohcy analysis, purposive reasoning, and process concerns into legal thought.").

120. Singer, supra note 49 , at 504. 


\section{B. The Politics of Indeterminacy}

What are the politics of the indeterminacy and "law is politics" critiques? It should be clear at the outset that the indeterminacy critique has no inherent politics: It can't; the indeterminacy critique cannot avoid being sucked down into the vortex of its own infinite regress. Followed to the necessary end of its logic, the indeterminacy critique inust undermine even the capacity to take a political stance and inake the political arguments that it purports to recommend. ${ }^{121}$ What is really underneath the law? Why, pohitics. And beneath that? Ideology, of course. And what does that rest on? Well, after that, it's still only turtles all the way down. ${ }^{122}$

Here, the Wittgenstein maneuver just won't work. For if the ineaning of politics and ideology coines froin "form of life," reason that law can't originate there, too. ${ }^{124}$ The indeterminacy critique cannot escape the infinite regress by seeking sanctuary in reflexivity, because that move is no less available to its target. ${ }^{125}$ And that, indeed, is one lesson of the legal realist precedent.

All that remains, then, is the indeterminacy critique as pure critique. But this means that, whatever legal regime might be in power-left or right - the indeterminacy critique would be available to undermine its clanns. ${ }^{126}$ This might appeal to soine, especially if one views the exercise of power as inevitably oppressive. But consider what this really ineans. A politics of pure opposition is itself defined by what it opposes. It can have no vision that is not already grounded (at least negatively) in the

121. See M. Merleau-Ponty, Phenomenology, supra note 18, at 168 ("We cannot have 'skeptical' politics because, appearances to the contrary, it chooses its goals and makes a selection of faets (which it then asks us to recognize) aecording to values it does not acknowledge, proposing to guide us to a definition of the 'possible' on the basis of these facts."); see also M. MERLEAU-PONTY, DiALECTIC, supra note 1, at 114-15 (complete skepticism as to "facts" makes all diseussion impossible).

122. See Wimter, Bull Durham, supra note 12, at $646 \mathrm{n} .37$ (collecting sources).

123. L. Wittgenstein, PhilosophiCal Investigations 88e (G. Anscoinbe trans. 1958) ("It is what human beings say that is true and false; and they agree in the language they use. That is not agrecment in opinions but in form of life.") (emphasis in original).

124. Karl Llewellyn understood this perhaps better than anyone. See supra text accoinpanying notes 60-62; infra text accompanying notes $169,172,253-58,36465$ \& 381-83.

125. To make this point clear, consider a variation on Roberto Unger's observation that "every branch of doctrine must rely tacitly if not explicitly upon some picture of the forms of human association that are right and realistic in the areas of social life with which it deals." $R$. UNGER, The Critical Legal Studies Movement 8 (1986). This "picture" does not take its form froin a "coherent, richly developed normative thcory," because there is none that can account for all the legal data. Id. at 9. But, then, where does it come from? Necessarily, it arises from the already extant social practices and conditions in which the relevant social actors are unavoidably situatedthat is, from existing forms of life. So where does law come froin? Why, from a prior picture of social relations. And where does that picture come from? Why, from those very soeial relations.

126. M. TUSHNET, supra note 3, at 317-18; Balkin, Deconstructive Practice and Legal Theory, 96 YALE L.J. 743, 786 (1987); Tushnet, supra note 43, at 516-17. 
given state of affairs. "[I]f one upsets the game in order to begin history again at zero, no one can say exactly what he is doing."127

As pure critique, the indeterminacy and "law is politics" critiques suffer the saine problem as permanent revolution. Permanent selfcriticism may seem attractive to the intellectual, but:

Unfortunately, a government, even a revolutionary one, a party, even a revolutionary party, is not a negation. In order to establisli themselves on the terrain of history, they must exist positively.... [There are only people] who think and wisl this or tliat, who are exuberant or discouraged, who see correctly or incorrectly, but who are in any case always in the world. . . A pohitical apparatus which functions on a day-to-day basis among [people] who are not all philosophers, who like to believe in their leaders or to lay the blame on them ... falls back into the positive witl all its weight. ${ }^{128}$

Without a basis for a positive prograin that escapes its own critique, the only certain thing is that some other, unknown but self-sustaining homeostasis will take its place. ${ }^{129}$ This means, of course, that the indeterminacy and "law is politics" critiques preordain their own marginalization.

Thus, the second lesson of the legal realist precedent is that, to the extent they succeed at all, the indeterminacy and "law is pohtics" critiques cannot expect success on their own terms. Those who would destabilize a normal science like constitutional law cannot expect the tradition to look to them for a way out of the crisis, no matter how cogent or "correct" the critique. That would happen only if progress and change were driven by logic (of the old-fashioned objectivist kind)-only then would the argument that trumps the old regime also replace it. Kuhn's point, however, is precisely that "rationality" is paradigmdependent-and, therefore, that "progress" is not linear. ${ }^{130}$ Rather, both "rationality" and "progress" are products of a homeostatic gestalt that destabilizes and reformnlates periodically. The reformulated paradigin will contain radical new elements which render determinate the very anomalies and critiques that caused the destabilization. It will also maintain substantial elements of the old paradigm, which is how it synthesizes a sense of continuity with the reality of change. ${ }^{131}$

127. M. MerleaU-PonTY, Dialectic, supra note 1 , at 183.

128. Id. at 89; see also id. at $135-36$ ("What one will have is not the already present and never completed revolution ... [but] continuous acts of rupture in the name of a utopia.").

129. Cf. id. at 183 ("The only thing which is sure is that . . yet another State will be manufactured. It may be good, mediocre, or bad; that remains to be seen.").

130. T. KUHN, supra note 15.

131. MacIntyre explains that, to resolve a crisis without abandoning the tradition altogether, a new paradigm will have to meet three conditions. First, it will have to be a "radically new" or "conceptually enriched scheme" in order to resolve the inadequacies and incoherences of the previous paradigm. A. MACINTYRE, supra note 41 , at 362 . Second, it will have to account for why the old paradigm failed. Id. Third, it will have to fulfill these conditions in a way that "exhibits 
Consequently, the most that can be expected as a result of attempts at destabilization is that the target system inay be induced to reformulate m order to restabilize. But it is a foregone conclusion that the reformulation will not be along the lines of the destabilizing critique. The destabilizations that provoke anomalies and deepen crises are predestimed for inarginalization. Crisis is followed inexorably by a new paradigm that resolves the old anomalies and once again inakes normal science possible. "Like a passion that one day just ceases, destroyed by its own duration, a question burns out and is replaced by an unquestioned state of affairs." ${ }^{132}$ A destabilizing critique will leave its marks on the subsequent paradigin, as legal realisin did. But its more radical destabilizimg elements will be normalized or marginalized in the new homeostatic systein. This is how we humans inake things work, how we stabilize ineaning in the face of contingency and flux.

Another marginalization also oceurs during times of crisis. Crisis provokes resistance, as the guardians of the failing paradigin attempt to circle the wagons in defense of the old ways. ${ }^{133}$ The current Court, for example, is increasingly prone to plain meaning arguments-which they seen to take quite seriously. ${ }^{134}$ Now, we inay know that there is no such thing as "plain meaning." But the Justices are situated in a belief system that takes as "objective" what is ouly conventional. They are not very likely to hear, let alone be persuaded by, an argument froin within the indeterminacy critique-whether the unknowability of the framers' intent, the polysemous character of language, or the contextuality of all meaning. In times of breakdown and crisis, there is no lingua franca.

Thus, the ultimate lesson of the legal realist precedent is that the indeterminacy position guarantees its own marginalization because no homeostatic system (which is to say no form of thought) can tolerate such radical destabilization. Those who would work for effective social change need to cultivate a healthier respect for the resilience of hoineostatic social systems. This does not inean, however, that the mdeterminacy critique is either wrong or a mistake (a point I return to below).

some fundamental continuity . . . with the shared beliefs [by] which the tradition . . . had been defined up to this point." Id. MacIntyre's first and third conditions are parallel to Kuhn's criteria. See T. KUHN, supra note 15, at 169.

132. M. MERLEAU-PonTY, SignS, supra note 25, at 3-4.

133. Resistance of this sort can be widespread. Accordingly, one sees that "a society's retreat in the face of a situation in which the contingency of moral and social structures is clear. It is the fear of the new which galvanizes and reaffirms precisely the very ideas that historical experience has worn out." Id. at 241. This may be an apt description of the Reagan-Bush era.

134. See, e.g., Mallard v. United States Dist. Court, 109 S. Ct. 1814, 1818-19 (1989) (relying in part on "common meaning" to find import of term "request" in statute is not equivalent to "demand" or "command"); Chan v. Korean Airlines, 109 S. Ct. 1676, 1680-81 (1989) (relying in part on dictionary to define "irregularity" of airline ticket under the Warsaw Convention). 
But it does mean that it runs the acute risk of incommensurability, like constitutional law in a foreign tongue.

\section{The Instability of Normal Science}

One of the frustrations with homeostatic systems of normal science is that, within their stabilized contexts, there is no orderly way to undo them. "Paradigms are not corrigible by normal science at all."135 But one of the mice things about such systems is their inevitable tendency toward entropy and collapse: Normal science "ultimately leads only to the recogmition of anomalies and to crises."136 Thus, one lesson of constitutional law in the moderu age is that there is no ultimate solution to the "problems" of constitutional law. ${ }^{137}$

As with all normal science, the process of concrete puzzle-solving eventually produces anomalies.

Produced inadvertently by a game played under one set of rules, their assimilation requires the elaboration of another set. After they have become parts of science, the enterprise, at least of those specialists in whose particular field the novelties he, is never quite the same. ${ }^{138}$

The two-tiered, adjudicatory paradigm of the post-New Deal era provided a stabilized matrix for constitutional adjudication for nearly thirtysix years: from West Coast Hotel v. Parrish ${ }^{139}$ to Roe v. Wade. ${ }^{140}$ Nevertheless, barely halfway through this period, the paradigm produced a decision so destabilizing that the enterprise of constitutional law would never be the same agaim.

The decision, of course, was Brown v. Board of Education. ${ }^{141}$ Brown is a textbook example of an anomaly because it is simultaneously the logical consequence of the reigning paradigm and the anomaly that would undo it. ${ }^{142}$ Initially, judicial protection of civil rights focused on

135. T. KUHN, supra note 15 , at 122 . This is not to say that it is impossible to effectuate change within a normal science. Rather, an understanding of the structure of a normal science makes effective strategic action possible. See Winter, Bull Durham, supra note 12, at 677-79; see also infra note 142.

136. T. KUHN, supra note 15 , at 122 .

137. Cf. M. MERLEAU-PontY, Dialectic, supra note 1, at 227 ("[A] system of conscious lives will never adinit of a solution the way a crossword puzzle does or an eleinentary problem of arithunetic.") (einphasis in original). On the other hand, we could reconceptualize our notions of problems and "solutions." See G. LAkOFF \& M. JoHnson, METAPHORS WE LIVE BY 143-44 (1980):

All of your problems are always present, only they may be dissolved and in solution, or they may be in solid form. The best that you can hope for is to find a catalyst that will inake one problem dissolve without making another one precipitate out. . . To ho he by the cheimical inetaphor would be to accept it as a fact that no problem ever disappears forever.

138. T. KUHN, supra note 15 , at $\mathbf{5 2}$.

139. 300 U.S. 379 (1937).

140. 410 U.S. 113 (1973).

141. 347 U.S. 483 (1954). Brown is further discussed at infra text accompanying notes 444-93.

142. Brown not only exemplifies how the very effectiveness of normal science can produce 
the rights of individuals to equal access to public facilities. ${ }^{143}$ As long as the Court dealt with only individual cases, the main thrust of the postNew Deal paradigm-deference to the majoritarian political process on most issues-remained intact.

But the logic of these paradigm-produced individual rights cases led inexorably to Brown. Inevitably, the attack on racial segregation challenged a practice that affected an entire class of people. Brown unsettled the paradigm because there was no sensible way to provide just individual relief; only structural intervention could provide a meaningful remedy. ${ }^{144}$ Thus, Brown followed from the paradigm and, by necessary implication, went beyond the interstitial, case-by-case efforts of the prior judicial decisions to the wholesale disapproval of the laws, mores, and social structure of an entire region.

Consequently, Brown opened up a tremendous anomaly in which judicial review was secn as imcreasingly undemocratic. ${ }^{145}$ This anomaly was so vital a threat to the paradigm that it received an official name: "tlie counter-majoritarian difficulty."146 In response to this anomaly, constitutional specialists debated the propriety of these judicial actions and the nature of their justificatory conceptualizations: "neutral principles," according to Wechsler, ${ }^{147}$ prudential and moral considerations, according to Bickel, ${ }^{148}$ "representation-reenforcing review," according to

anomaly, but it also illustrates how strategic action within normal science can be used to exploit that tendency in the service of fundamental change.

One of the most important of the passive virtues has historically been the property of randomness in the flow of litigation, whicl made it unlikely that the Court, after deciding any given case, would immediately be faced with the situation that most stringently tested the principle enunciated. It is precisely this saving element of aceident, this opportunity to avoid the testing of the outermost limits of a principle, that has been eliminated by the activity of groups whose aim it is to utilize litigation as a means of pursuing social goals.

Deutsch, supra note 106, at 222-23.

143. See Missouri ex rel. Gaines v. Canada, 305 U.S. 337 (1938) (admission of blacks to state law school); Mitchell v. United States, 313 U.S. 80 (1941) (access of blacks to equal rail facilities); Sipuel v. Board of Regents, 332 U.S. 631 (1948) (admission to law school); Sweatt v. Painter, 339 U.S. 629 (1950) (access to equal law school education); McLaurin v. Oklahoma State Regents, 339 U.S. 637 (1950) (access to equal graduate school facilities).

144. See Potts v. Flax, 313 F.2d 284, 288 (5th Cir. 1963) (arguing that class-wide rehef would be necessary even in an individual case). I discuss Potts as an exemplar of a comnunal nodel of adjudication in Winter, The Metaphor of Standing, supra note 12, at 1501.

145. Cliemerinsky, supra note 97, at 63-64; Deutscl1, supra note 106, at 183-84 ("constitutional adjudication is ... an anomaly in a democratic society, ... a process in which a politically irresponsible institution reviews the acts of duly elected legislative and executive officials"); see also Amar, Law Story, 102 HARv. L. REV. 688, 703-05 (1989) ("Brown called into question every central tenet of the legal process theory enibodied in the first edition of The Federal Courts and the Federal System.").

146. A. Bickel, The Least Dangerous Branch: The Supreme Court at the Bar of PoLITICs 16 (1962).

147. Wechsler, supra note 112.

148. A. BICKEL, supra note 146. 
Ely. ${ }^{149}$ Not everyone, of course, saw the paradigm as internally coherent and rationally defensible; even during this period of stabilization, some understood the historically and culturally contingent nature of reasoning in constitutional decisionmaking. ${ }^{150}$ But, as Kuhn reports, the claims of authentic pioneers are rarely persuasive absent a full-blown crisis that shakes the profession's faith in its reigning paradigm. ${ }^{151}$

Roe reopened and deepened the anomaly. ${ }^{152}$ What's more, it did so at a time of substantial cultural and political ferment: the end of the Vietnam War era, the cooling of 1960s passions, the resurgence of the feminist movement, the Watergate crisis. Not incidentally, this is also when the critical legal studies movement is born. ${ }^{153}$ Its birth marks the beginning of another period of crisis.

Critical legal studies, like legal realisin before it, has inade invaluable contributions-deepening our understanding and advancing the transformative process of crisis and transition. Indeed, one just doesn't think about constitutional law the same way after a decade and a half of critical legal studies. A thoughtful, well-conceived casebook like Gerald Gunther's classic (classic, that is, relative to constitutional law as a normal science circa 1975$)^{154}$ begins to seem almost quaint: a relic of a simpler time when things like "means/ends analysis," "two-tiered equal

149. J. ELY, supra note 6.

150. With regard to Wechsler's call for neutral principles, Deutsch observes that "the insight that the historical context may well determine the proper classification of a given principle," means that

a neutral principle becomes one that is perceived as adequately general in terms of the historical context in which it is applied. The question that such a reformulation raises, however, is this: perceived as adequately general by whom? ... [P]erceived as adequate by the very society that imposes the requirement of adequate generality to begin with ....

Deutsch, supra note 106, at 195 . With regard to Bickel's formula for the savvy mix of principle and prudence in judicial review, Deutsch observes:

The limitations that have thus helped to make the Court's work manageable are not to be found explicitly set out in the constitutional texts. They exist, rather, as cultural understandimgs, as implicit assumptions, and it is precisely these agrecments that have increasingly been breaking down.

Id. at 224.

151. T. KUHN, supra note 15 , at 75.

152. See J. ELY, supra note 6, at 2-3 ("[T] he controversial abortion decision of 1973, Roe v. Wade, ... forced all of us who work in the area to think about which camp we fall into ....").

153. See Fletcher, Why Kant, 87 CoLuM. L. REv. 421, 424-26 (1987) (applying Kuhn's analysis and identifying a school or movement as a group sharing a common text and common questions, thus locating critical legal studies' origin with the publication of Roberto Unger's Knowledge and Politics in 1975 and Duncan Kennedy's Form and Substance, supra note 43, in 1976). For accounts of the impact of these contemporary phenomena on the founders of critical legal studies, see Gordon, New Developments in Legal Theory, in The Politics of LAw: A Progressive Critique 281, 28384 (D. Kairys ed. 1982) [heremafter The Polrtics of LAw]; Binder, On Critical Legal Studies As Guerrilla Warfare, 76 GEO. L.J. 1, 14-24 (1987).

154. See G. GunTHER, Preface to the Ninth Edition, in ConstrTutronal Law at xxiii-xxiv (11th ed. 1985) (outline prepared with Herbert Wechsler in the 1960s forned the basis for the seventh and eighth editions; its "inprint remains strong" even in the ninth edition published in 1975). 
protection analysis," and "strengthened 'rationality' scrutiny" with "bite"155 actually seemed to mean something. As a result of the increasing application of the "law is politics" and indeterminacy critiques to actual legal doctrines and constitutional theories, what was for quite soine time a tolerable anomaly looks more and more like a crisis that is out of control. ${ }^{156}$ For example, Mark Tushnet lias argued that no one of the Grand Theories of constitutional law can solve the anomaly and save the paradigm. ${ }^{157}$ This is as we might expect if, as I have argued above, objectivism is a inyth and rationality a function of stabilized inatrices. As Jan Deutscli observed as early as 1968, "tlie breakdown of accepted limitations on the meaning of legal concepts, most evident in constitutional law but by no means confined to that area, makes it increasingly difficult to fornulate even partially complete and coherent systems."158

In Bull Durham and the Uses of Theory, I hazarcled the claim that we are now in the throes of a full-blown crisis. ${ }^{159}$ If this claim is right, then we sliould expect a paradigm shift within the next few clecades. In the context of this cycle of crisis-to-paradigm-shift, there are two basic strategies: (1) One can try to implement one's affirmative program by trying to appeal to (and/or reconstruct) a normal science from within; or (2) one can try to unclermine an existing normal science by provoking or deepening crisis. But if one chooses tle latter - and there are times when that clioice is appropriate-then one must accept the fact that one has unavoidably cliosen marginalization.

There is, however, another alternative. One way to appeal to a normal science under attack is to offer a new paradigm or radical way out of the crisis that, nevertheless, inamtains enough of the old tradition to assuage the inevitable drive for homeostasis. Personally, I think that is where we sliould concentrate our efforts. This reconstructive project does not mean that we should give up the hard-won insight that law is

155. See Gunther, The Supreme Court, 1971 Term-Foreword: In Search of Evolving Doctrine on a Changing Court: A Model for a Newer Equal Protection, 86 HARv. L. REV. 1, 20-24 (1972).

156. See T. KuHN, supra note 15, at 67-68:

[T] he awareness of anomaly [lasts] so long and [penetrates] so deep that one can appropriately describe the fields affected by it as in a state of growing crisis. Because it demands large-scale paradigm destruction and major shifts in the problems and techniques of normal science, the emergence of new theories is generally preceded by a period of pronounced professional insecurity. As one might expect, that inisecurity is generated by the persistent failure of the puzzles of normal science to come out as they should. Failure of existing rules is the prelude to a search for new ones.

157. M. Tustnet, supra note 3, at 21-146. For an excellent discussion of the failings of various versions of republicanism and communitarianism to provide a coherent theory for judicial review, sec Kahn, Community in Contemporary Constitutional Theory, 99 YALE L.J. 1 (1989) (discussing Ackerman, Michelman, Sunstein, Fiss, Cover, and Dworkin).

158. Deutscl, supra note 106, at 235.

159. Winter, Bull Durham, supra note 12, at 671, 679-81 (arguing that the legal academy is currently in the kind of episteinological crisis that typically presages a paradigm shift). 
politics, just that we should relinquish our unsophisticated notion of politics. $^{160}$

\section{IV \\ The Meanings of Constitutional Politics}

\section{A. The Politics of Epistemia}

Only an impoverished notion of politics-and a correspondingly narrow conception of law-would translate both legal realism and critical legal studies into instrumentalism. What is dramatic, important, and positive about these critiques is their philosophical pragmatism, not their crass instrumentalism. The slogan "law is politics" is true enough, but we should be quite careful not to reduce it (and our claims) to a naive "tliey do whatever they please." "Ideology" is not itself a sufficient explanation for the law; there remain the obvious questions of where the socially situated individual gets his or her ideology and, even more importantly, how that ideology affects decisionmaking in either law or politics.

An effective constitutional pohitics must pay close attention to the larger cultural constructs and stabilized matrices in which lawyers, judges, and laypersons are always already situated. The mutual entailment of the epistermic and the political means also that the epistemic, the political, and the legal are already one. Consider the following example from an ongoing debate in constitutional theory. Mark Tushnet has argued that Ronald Dworkin's distinction between a constitutional "concept," the idea or principle incorporated into a constitutional provision, and the particular "conceptions" expressed by the framers ${ }^{161}$ is subject to mampulation by varying the level of generality. ${ }^{162}$ In Bowers $v$. Hardwick, ${ }^{163}$ for example, the majority opted for a relatively particularized cliaracterization. Accordingly, it found no privacy right because our historical and constitutional tradition liad never sanctioned homosexual sodomy. ${ }^{164}$ The dissent, on the other hand, chose a more generalized formulation. It would have found a privacy right because of our society's general commitment to privacy in matters of sexuality. ${ }^{165}$

160. See also Schlag, Images of the Political: The Normative and the Epistemic (forthcoming 1991) (questioning the dominant normative understanding of "law is politics").

161. R. DWORKIN, supra note 4, at 70-72; R. DWORKIN, TAKING Rights SERIOUSLY 134-36 (1977).

162. M. TUSHNET, supra note 3, at 135 .

163. 478 U.S. 186 (1986).

164. Id. at 190-94.

165. M. TusHNET, supra note 3, at 135 (discussing Bowers, 478 U.S. at 199 (Blackmun, J., dissenting)). Subsequently, Justice Scalia lias suggested that the way to avoid indeterminacy and value-imposition is to fix the level of generality at "the most specific level at which a relevant tradition protecting, or denying protection to, the asserted right can be identified." Michael H. v. 
At this point, Philip Bobbitt joins the debate and argues that Tushnet has it wrong because, at least in the case of unenumerated rights, the level of generality has nothing to do with it. ${ }^{166}$ Invoking a variant of the modern constitutionalist's favorite distinction-the ineans/ ends distinction-Bobbitt argues that the level of generality doesn't matter because it isn't the permissibility of the desired legislative end (that is, whether it is seeking to regulate homosexual sodomy or intimate sexuality) that determines the statute's constitutionality. It is, rather, a question of permissible means: Are the means constitutionally compatible with the American ethos of limited government? And he answers this question too without resorting to ends by imvoking a structural analogy and arguing that: "If a particular statutory means is denied to the federal government, then it is denied to the states, even if the goal involved is permitted to the states."167 Thus, he concludes:

Even if the purpose of the statute were to promote world peace and harmony and every single American took an oath claiming to behieve that statute would dehiver it, the means employed might still offend our ethos. If the majority in Bowers is persuasive, it is precisely because the actual conduct of homosexual sodomy did not, traditionally, correspond to our notions of intimacy but instead seeined (perhaps erroneously) more like licentiousness. Whether or not the argument regarding Roe is persuasive also depends on whether the specifics of a woman's carrying a fetus to term corresponds to our ideas of intimacy. If they don't, then the level of generality-whether or not Americans want to protect privacy, on the one hand, or fetal life on the other-is simply irrelevant. ${ }^{168}$

But is it? The last two sentences seem to contradict each other. How can the level of generality be irrelevant when the legitimacy of Roe "depends on whether the specifics of a woman's carrying a fetus to term corresponds to our [general] ideas of intimacy"? It seens obvious that if the judges see preguancy as "intimate," the case is won. But if they see pregnancy as pregnancy, or sex as procreation, then the case is already lost before one gets anywhere near the Constitution.

Does that mean that the generality version of the indeterminacy critique is correct? Well, almost. What is more to the point, and much

Gerald D., 109 S. Ct. 2333, 2344 n.6 (1989) (joined only by Rehnquist, C.J.). For an effective rebuttal of Scalia's proposal, see Tribe \& Dorf, Levels of Generality in the Definition of Rights, $57 \mathrm{U}$. CHI. L. REv. 1057, 1085-96 (1990). Tribe and Dorf's own proposal for ascertaining appropriate levels of generality is superior to Justice Scalia's only in that it does not pretend to value-neutrality. It fails, however, to survive its own critique. Because it relies almost entirely on convention as the unediating device for ascribing characterizations to traditions of legal precedent, it fails to account for the effects either of unexamined cnltural processes of categorizations (see discussion at infra text accompanying notes 169-72) or of cultural change and reinterpretation (see discussion at infra text accoinpanying notes $330-419$ ).

166. Bobbitt, supra note 45, at 1294-96.

167. Id. at 1296.

168. Id. 
more revealing, is that all the legal and pohtical work of constitutional decisionmaking is being done at the epistemic level. Roe and Bowers both depend on preexisting, extra-legal (which is to say, cultural) processes of categorization. What ultimately decides the issue is not the legal rule, but rather the concept of "intimacy" that the judges bring to the case. ${ }^{169}$ If the judges know intimacy only in the context of a traditional heterosexual marriage, if they know lesbians and gays only as Other, then Bowers is always and already lost. But if the society is one in which hoinosexual relationships can be seen and inanifested in all the tender, loving capacities that human relationships can muster at their best, if the judges know of such people and can see thein as people just like themselves, then the case is won (or, better yet, might never need to be brought).

What I think we should conclude from this discussion is that an effective constitutional pohtics must begin long before the questions of legal doctrine and its manipulability are reached. The inutual entailment of the epistemic and the political means that not only is law politics, but also-more importantly - that law is nested in and entirely contingent on the wider social practices and understandings that are sedimented in any culture. ${ }^{170}$ The assertion tliat presidents and legislators "tend to deal with fundaniental pohtical-moral problems . . . by reflexive reference to the established moral conventions,"171 necessarily applies equally to judges. Because those conventions are already entailed in our language and already entrenched in our conceptualizations, there is little else to which they could refer. ${ }^{172}$

This insight requires that we cultivate a truly praginatist politics that struggles with the mucli harder task of making constitutional inean-

169. Although I come to the insight by way of cognitive linguistics, see Winter, Transcendental Nonsense, supra note 12, at 1151-56, 1180, the point was made by Karl Llewellyn 55 years ago: "[1]f there is any slightest doubt about the classification of the facts-though they be undisputed-the rule cannot decide the case; it is decided by the classifying." Llewellyn, supra note 65 , at 8 (citation omitted).

170. For demonstrations, see Winter, The Cognitive Dimension, supra note 12, at 2267-71 (affirmative action); Winter, Transcendental Nonsense, supra note 12, at 1186-96 (first amendment). For further discussion and examination of the concept of "sedimentation," see infra text accompanying notes $236-72$.

171. M. PERRY, supra note 8, at 100; see also id. at 101 (clraracterizing the political branclies in contradistinction to the judiciary).

172. Judges see these institutions not as they are, but through the spectacles (a) of what tlicy may have been, (b) of the honorably received ideology about them-whicls is of necessity vastly older than themselves. ... The picture fits into a background shaped in unthinking childlood, uncritically accepted, all deviating and modern factors slighted.

Llewellyn, supra note 65, at 34 (emplrasis in original); cf. Deutscl, supra note 106, at 260 ("[T]lie search for factors that effectively impose restraints on the discretion of the individual Justice mnst be carried beyond the realm of his work experience to that of his schooling, botls formal and informal."). 
ing. As I explain below, this task is inuch inore difficult than might be assumed. It calls for a constitutional politics of a different order.

\section{B. The Politics of the Subject}

In assessing the inagnitude of a truly constitutional politics, we can quite profitably beginı with Frank Michelman's plea for a "dialogic conception of pohtics."173

Pragmatic political argument is animated and constrained by a consciousness of its situation within, and answerability to, a public normative culture and history-within and to, if you like, a normative practice. . . . If pragmatic political argument does locate itself witlin a public normative history, it also adopts a critical and always potentially transformative attitude toward that history. It regards that history as always containing resources that can be apphed to its own critical reexamination and, therefore, as always ripe for the transformative exercise of what has been called interpretation, or internal developinent, or recollective imagimation. ${ }^{174}$

This passage highlights the idea that all argument is sliaped by its situation, its normative culture, and its history and at the same time is always in the process of transformative elaboration. In this view, what is noteworthy about Miclielman's description of dialogic pohtics (and rare in legal scliolarship) is the recognition tliat human endeavor is simultaneously situated and imagniative. ${ }^{175}$ Yet, even Michelman's description falls short in three critical respects that, ultimately, undermine lis stance. As I will show, each of these shortcomings is nested in a single more fundamental misconception.

First, Michelman's conception of "dialogue" is mucli too polite and intellectualized. ${ }^{176}$ In a world in which even the most civilized order does violence in its day-to-day operations, ${ }^{177}$ meaning frequently must be

173. Michelman, Bringing the Law to Life: A Plea for Disenchantment, 74 CoRNELL L. REv. 256, 257 (1989).

174. Id. at 258 (footnotes omitted).

175. The other notable exception in the hiterature is Drucilla Comell's Institutionalization of Meaning, Recollective Imagination and the Potential for Transformative Legal Interpretation, $136 \mathrm{U}$. PA. L. Rev. 1135 (1988), to which Michelman exphicitly refers.

176. See K. WHITESIDE, supra note 16 , at 265 ("intellectuals . . . are particularly prone to believing that it is possible to translate ideals directly in practice"); Schlag, Missing Pieces: $A$ Cognitive Approach to Law, 67 TEx. L. Rev. 1195, 1210 (1989) ("The hallmark of rationalist consciousness is the privileging of ego-centered reason.").

177. See M. Merleau-Ponty, Humanism and Terror: AN ESSay on the Communist Problem 33-36 (J. O'Neill trans. 1969); Cover, Violence and the Word, 95 YALE L.J. 1601, 1601 (1986); see also K. WHITES1DE, supra note 16, at 188-89 (summarizing Merleau-Ponty's view: "[L]iberals tend to overlook the complicity of their principles with the violence of political life. Liberalisun is an ideology in the phenomenological sense-not a 'mask' for practice, but the existential accompaniment of concrete political decisions.") (citations omitted). 
written " $\mathrm{m}$ the medium of blood."178 To the extent that meaning is grounded in a form of life, it follows that "[t]o make meaning, one must do meaning." 179 Constitutional meaning - and, therefore, constitutional pohtics-depends upon more than argument or pure politics; constitutional meaning depends as well upon a dialogue that is founded in and sustained by lived human experience and committed action. "[P]rescription, even when einbodied in a legal text, [cannot] escape its origin and its end in experience...."180 Indeed, constitutional meaning begins in the grounded cognitive process by which we translate social experience into cultural meaning.

If today we believe it reasonable . . . that workers attain more than a marginal economic existence or if we find racism detestable, it is because people struggled, through strikes and protest and violence, to vindicate those claims. That is to imply that concrete events, not just abstract reasoning ... are responsible for constituting what is rational. ${ }^{181}$

178. Cover, The Supreme Court, 1982 Term-Foreword: Nomos and Narrative, 97 HARV. L. Rev. 4, 47 (1983).

179. Winter, Transcendental Nonsense, supra note 12, at 1231 (emphasis in original); see also Law, Equality: The Power and Limits of Law, 95 YALE L.J. 1769, 1783 (1980) ("Even the most fundamental negative rights, such as the right to speak or to control our bodies free from governmental constraint, acquire concrete meaning only as people act collectively to claim them.").

Michelman approaches this insight in his deft argument-building on Justice Blackmun's dissent in Bowers, 478 U.S. at 204-05-that the right to a homosexual lifestyle can be grounded in an associational right because it "has come to signify ... a more personally constitutive and distinctive way, or ways, of being." Michelman, supra note 96, at 1533. Michelman is persuasive on this point. See infra text accompanying notes 511-22. But he fails, I think, to appreciate its full import: If activity and behavior are accorded protection because they are now understood to be constitutive of self and meaning, then mutually conflicting forms of life must be equally protected.

The depth of the conflict this creates for Michelman becomes clear when one cousiders his argument for banning pornography because it promotes subordination of women and, as such, causes them harm. See Michelman, supra note 96, at 1532 n.161. The argument founders becanse to concede that pornography expresses a point of view on the subordination of women is to concede that it has a constitutive effect for its consumers (however disgraceful and unrcconstructed they may be). Cf. Stanley v. Georgia, 394 U.S. 557, 567 (1969) ("[T]he State may no more prohibit mere possession of obscene matter on the ground that it may lead to antisocial conduct than it may prohibit possession of chemistry books on the ground that they may lead to the manufacture of homemade spirits.").

Worse yet, Michelman's argument for banning pornography undermines his Bowers argument. As he acknowledges, stable homosexnal relationships are uniquely threatening to conservative values. Michelman, supra note 96, at 1533 n.166 (quoting Law, Homosexuality and the Social Meaning of Gender, 1988 WIs. L. REv. 1, 24, 31-32). But the very reason that legislative majorities have traditionally sought to ban homosexual conduct is that they experience it as harmful to the security of their heterosexnal family values (although, in my view, they are wrong and mistaken in this behief).

It is difficult to see how Michelman's republican pluralism helps us mediate such conflicting world views. In the end, one suspects that the choice and imposition of values (for homosexual privacy, against pornography) cannot be avoided. One may find these values laudable, as I do, but they are not derivable from or materially advanced by Michelman's republicanism.

180. Cover, supra note 178, at 5 .

181. K. WhITESIDE, supra note 16, at 98. Michelman comes close to this insight when he discusses the role of "action" in producing what he refers to as "generative indeterminacies." 
This is the lesson of the Edmund Pettus Bridge and the Voting Rights Act, ${ }^{182}$ the Civil War and the fourteenth amendment, indeed of the American Revolution and the Constitution itself.

Second, Michelman's dialogic politics is far too rationalist to realize his transformative aspirations. As long as Michelman rehes on "interpretation" and recognizes an "answerability to ... a pubhic normative culture,"183 his conception of politics remains too closed, too static, too bound by normal science and its internal processes. ${ }^{184}$ As Kuhn has noted: "Given a paradigm, interpretation . . . is central to the enterprise that explores it. But that interpretive enterprise ... can only articulate a paradigm, not correct it." 185

It is true, of course, that Michelman has questioned Kuhn's periodization of normal science and crisis and allied himself with Feyerabend's notion that science always contains the inarginal as well as the normal. Thus, for Michelman, "[a] shift from pre- to post-transformation practice is inore like a moveinent from inargin to center-a shift of attention-than it is like the total replacement of one 'world' by

Michelman, supra note 96, at 1529. Thus, he points to the role of "self-emancipatory activity of Black Americans" in shaping the meaning of equal protection during the Warren Court era. Id. at 1529-30. It is unclear, however, that he means the same thing by "action." For, after stating that generative indeterminacies "are products of action, the creations of motivated acts of perception and cultivation," he immediately follows with the question: "Action by whom, then? Most likely, it would seen, by those who enter the conversation ...." Id. at 1529 (emphasis added).

Similarly, the lesson that Michelman draws from the civil rights movernent concerns not the necessity of action, but rather the locus of dialogue. The civil rights movetnent, he suggests, counsels an expanded sense of "dialogic engagement," "in the encounters and conflicts, interactions and debates that arise in and around town meetings and local government ageneies; civic and voluntary organizations; ... workplaces and shop floors; public events and street life; and so on." Id. at 1531. But the kinds of concrete, even bloody experiences identified by Whiteside and Cover as a ground for meaning seein remarkably absent from this version of Michelman's conception of "normatively consequential dialogue." Id.

In forthcoming work, Michelman comes closer still: He recognizes the communicative content of action. Nevertheless, there is a subtle but important difference betwecn recognizing that action can express (syınbolic) meaning and understanding that action constitutes ineaning. See infra text accompanying notes 240-48 \& 286-306.

182. See, e.g., J. Williams, Eyes on the Prize: AmericA's Civil Rights Years, 1954 1965, at 252-85 (1987) (detailing the events at Selma that led to the passage of the Voting Rights Act); see also Fiss, The Law Regained, 74 CORNELl L. REv. 245, 250 (1989):

Political activity and organization is often needed ... to cliallenge the unsatisfying answers courts sometimes give to the aggrieved .... Sometines that political activity proceeds in lieated and unruly ways-that too is a lesson of the civil rights era. Courts heard what the people were saying at the lunch counters of Grecnville, on the streets of Birmingham, and on the road from Selma to Montgoinery, and responded accordingly.

183. Miclielman, supre note 173 , at 258 .

184. And, thus, le risks much the same stasis that he identifies as the shortcoming in Ackerman's approach. Michelman, supra note 96, at 1521-24 (discussing Ackerman, Storrs Lectures, supra note 5).

185. T. KuHN, supra note 15, at 122; see also id. at 123 ("No ordinary sense of the term 'mterpretation' fits these flasles of intuition through which a new paradigm is born."). 
another." 186 But this alliance with Feyerabend is an improbable one. Feyerabend's view of the simultaneity of normal and marginal science explains the shift from one to the other as a product of blind contingency. ${ }^{187}$ "Revolutions," according to Feyerabend, "are the outward manifestation of a change of the normal component that cannot be accounted for in any reasonable fashion."188 Feyerabend sees scientific revolutions as no more than a chance shift in attention because he is an antirationalist. But Michelinan is advocating "a communicative practice of open and intelligible reason-giving." 189 He wants people to change their positions in response to dialogue, because they are persuaded by reasons. In the end, Feyerabend's nonrational skepticism is incommensnrate with Michelman's description of situated normative dialogue.

Thus, Michelman cannot cherish "all moments as potentially transformative"190 and still insist on dialogue as the modality of transformation. "Intelligible reason-giving" depends on a stabilized inatrix that establishes a context for communication, ${ }^{191}$ as Michelman does acknowledge elsewhere: "The persuasive character of the process depends on the normative efficacy of some context that is everyone's-of the past that is constitutively present in and for every self as language, culture,

186. Michelman, supra note 96 , at 1523 (discussing Feyerabend, Consolations for the Specialist, in CRITICISM AND THE GROWTH of KNOWLEDGE 197, 207-10 (I. Lakatos \& A. Musgrave eds. 1970)); $c f$. R. UNGER, supra note 125 , at 15-22, $88-90$ (discussing the practice of deviationist doctrine).

187. The younger generation, always eager for new things, seizes upon the new material and studies it avidly. Journalists, always on the lookout for headlines-the more absurd, the better-publicize the new discoveries.... These are some reasons for the differences which we perceive. I do not think one should look for anything more profound.

....

... [T]o assume that ... people will change their allegiance in a reasonable fashion is carrying optimism and the quest for rationality too far. The normal elements, i.e. those elements which have the support of the majority, may change because the younger generation cannot be bothered to follow their elders; or because some public figure has changed his mind; or because some influential member of the establishment has died and has failed (perhaps because of his suspicious nature) to leave behind a strong and infiuential school, or because a powerful and non-scientific institution pushes thought in a definite direction.

Feyerabend, supra note 186, at 213-14 (emphasis added).

As I have explained elsewhere, this invocation of blind contingency is the common and inevitable conclusion of all social coherence theories. For a discussion of these problems with respect to Rorty's account of scientific progress, see Winter, Transcendental Nonsense, supra note 12, at 112327. For a discussion of these problems with respect to Fish's account of change, see Winter, Bull Durham, supra note 12 , at 664-76.

188. Feyerabend, supra note 186, at 214 (emphasis added).

189. Michelman, supra note 7 , at 34 .

190. Michelman, supra note 96 , at 1523 .

191. "Human society is not a community of reasonable minds, and only in fortunate countries where a biological and economic balance has locally and temporarily been struck has such a conception of it been possible." M. MERLEAU-PONTY, PhenomenOlogy, supra note 18, at 56; $c f$. Michelman, supra note 96, at 1506 (repubhican constitutionalism may not be possible in modern American society because, historically, it has "usually imvolv[ed] some combination of political hierarchy, civic regimentation, and organicist culture"). 
worldview, and political memory." 192 But, as we have seen, stabilized matrices are largely secure from penetration by precisely those arguments that might undo them. ${ }^{193}$ This is another way of saying that Michelman, too, is ensnared in the quandary of constitutional theory in a conservative era.

The third and closely related difficulty is that Michelman conceives of public normative culture and history as "always being ripe" for transformation through rational argument; ${ }^{194}$ he recognizes neither inertia nor resistance. Yet, there is "an adversity which hides it from the grasp of the strongest and the most intelligent of men." 195 This adversity is, typically, more visible to those who understand the world as a product of blind contingencies for, otherwise, radical change would be a rather effortless and more common event. Thus, Feyerabend complains that the hegemony of scientific culture renders it largely secure from challenge: "What is worthwhile and what is not are to such a large extent determined by the existing institutions and forms of life that we hardly ever arrive at a proper evaluation of these institutions themselves."196 But those who, like Michelman, are committed to reason have a tendency to see the social world as comphant to that reason. ${ }^{197}$

The very fact that we are always already situated-that is, constituted in part by culture and history-means that it is difficult for us to get underneath the particular turtle upon which we stand. ${ }^{198}$ Adversity is the "inertia of the infrastrnctures" that are the grounds of human possibility. ${ }^{199}$ This phenomenon is manifested no less in the sphere we

192. Michelman, supra note 96, at 1513 (emphasis in original).

193. See supra text accompanying notes 31-39 \& 129-34.

194. Michelman, supra note 173, at 258. Ironically, Michelman nakes a closely related point in his response to Owen Fiss: " 'Crit' scholars, using a different vocabulary froun Fiss's, might have chosen the term 'reification' for the sort of obstructive intellectual force of which he complains." Id. at 269.

195. M. MERLEAU-PONTY, SIGNS, supra note 25, at 218; see also id. at 239 ("a inatter of a sort of inertia, a passive resistance, a dying fall of ineaning -an anonymous adversity") (emphasis in original).

196. Feyerabend, supra note 186, at 209. Thus, Feyerabend's explanation of why "the revolutionary elements become visible only on such rare occasions" as described by Kuhn (that is, in times of crisis) is that the resistance of the institutional structures of normal science "becones especially strong and noticeable in periods where a change seems to be imminent." Id. at 213. But, as noted above, Feyerabend argues that it is pure contingency that brings on such change. See supra note 187.

197. See Schlag, supra note 176, at 1211 ("[Inn primciple, the rationalist self knows few (if any) limits on its capacity to understand or explain the world ....").

198. Stanley Fish takes the extreme position that it is never possible to do so. See S. FisH, supra note 36, at 467 (There can be no "option of stepping back from one's beliefs in order to survey or reform thein" because "being situated ... Ineans that one cannot achieve a distance on one's beliefs."). For a demonstration that reflection-what I call "situated sclf-consciousness"-is possible, see Winter, Bull Durham, supra note 12, at 661-64, 681-84.

199. M. MerLeAU-PonTY, Dialectic, supra note 1, at 64 . Van Zandt makes a closely related critique of Unger. See Van Zandt, Commonsense Reasoning, Social Change, and the Law, $81 \mathrm{Nw}$. 
denominate political than in the personal one: "Inertia is a guiding principle in politics as well as pliysics, and the very existence of our institutions-the persuasive testimony of history-itself serves to produce a significant degree of acceptance.",200

Ultimately, eaclı shortcoming in Miclielman's description of dialogic politics is related to a single, inore fundamental issue: the nature of subjectivity. Consider the subject to whom Miclielman addresses his plea for a dialogic conception of pohtics. It is, first of all, a subject capable of deciding whetlier to heed this plea. ${ }^{201}$ It is a subject that, although "answerable" to a "public normative culture,"202 is presumedly free (at least initially) to disregard that culture. This subject "locate[s] itself within a public normative history."203 "[I]t also adopts a . . transformative attitude toward that history."204 Now, this is hardly a subject constrained by its situation. Indeed, in Miclielman's actual formulation, the subject is constramed because it chooses to be constramed-tliat is, it is "constrained by a consciousness of its situation."205

In slort, Michelman's subject is a relatively autonoinous subject. ${ }^{206}$ Thus, this subject purports to be able to inake meaning solely througl intellectual argument, to shift its attention freely froin center to margin in searcli of transformative possibilities, and to do so witlout let or hindrance froin history, culture, or institutions. Miclielman's subject is liardly situated at all; on the contrary, it is capable of lolding history at a

U.L. REV. 894, 921 (1987) ("[I]t is precisely because formative contexts are individuals' own products whose pragmatic utility is constantly reaffirmed through daily use that they take on a correctness or plausibility that is difficult to challenge.").

200. Deutsch, supra note 106, at 216.

201. Thus, Michelman suggests that "legislatures restricting constitntionally valued hiberties ... in genuine and reasonable pursirit of constitutional values carrying greater weight" might more readily be believed by a Court willing to "ask whether those who suffer restrictions of their hberties ... can fairly be expected to accept that restriction as consonant with a good-faith exercise in dialogic politics." Michelman, supra note 173, at 267-68. But does anyone serionsly think that the $\mathrm{Ku}$ Klux Klan can be persuaded by dialogue to accept a legal restriction on, or to give up the right to, racially derogatory speech? Can a doctrine of implied (dialogic) consent be far behind?

202. Id. at 258.

203. Id. (einphasis added).

204. Id. (einphasis added).

205. Id. (einphasis added). Michelman is joined by Duncan Keimedy in just this mistake. See Kennedy, A Cultural Pluralist Case for Affirmative Action in Legal Academia, 1990 DuKE L.J. 705, 745 ("[C]ulture and ideology provide a vocabulary from which 'individuals' pick and choose to produce themselves ....").

206. The phrase is Pierre Schlag's. Schlag, supra note 14, at 37 . Within the legal acadeiny, Stanley Fish and Pierre Schlag have done the most to make ns conscious of the significance of situatedness and the degree to which legal sclolars unconsciously presuppose a classical transcendental subject. See generally S. FisH, supra note 13; Schlag, supra note 176; Schlag, "Le Hors de Texte, C'est Moi"--The Politics of Form and the Domestication of Deconstruction, 11 CARDozo L. Rev. 1631 (1990). The ideas in these paragraphs owe much to their work and to hours of intense conversation with Pierre. 
distance so that it can "regard" it as a "resource."207 Indeed, in just this syntactical way, Michelman's formulations constantly reproduce the subject/object dichotomy: He speaks of the subject and its history, the subject answerable to its culture, the subject adopting an attitude toward history, the subject transforming that history. ${ }^{208}$

Perhaps I am being unfair to Michelman. ${ }^{209} \mathrm{He}$ does, after all, set out to acknowledge the situatedness of political argument. He recognizes that it takes place (read: it must necessarily take place) within a given history and normative culture. Indeed, that is why, with no irony intended, I can refer to his position as a "profitable" place to begin. Nevertheless, an undertone of autonomous subjectivity keeps breaking through the surface of Michelman's discussions of situatedness.

We can see this process at work in his description and rejection of "strong republicanisin.""10 In this version of republicanisin, "[p]ohitical engageinent is considered a positive human good because the self is understood as partially constituted by, or as coming to itself through, such engagement."211 The suspicion that this really is a self-constituting consciousness (rather than a situated, constituted self) is confirmed when he tells us that one advocate of strong republicanism is Kant, who, he suggests, contends: "[W]e are frce only insofar as we direct our actions im accordance with reasons or ends that we, as it were, legislate to ourselves upon conscious, critical reflection."212 Michelman hesitates to recominend strong repubhicanism only because he is not willing to accept its transcendentalist underpinnings. ${ }^{213}$ Nevertheless, he exphicitly endorses the supervenient role of consciousness. ${ }^{214}$

Thus, in his description of republican jürisgenesis, Michelman reduces situatedness to "a fund of public normative references conceived as narratives, analogies, and other professions of commitnent" upon which "subjects draw."215 What is salient about this "fund" is that it

207. Michelman, supra note 173 , at 258 ; see also Schlag, supra note 176 , at 1237 (discussing the "tendency of thought to solidify into opaque substances that can be carved and dissected, as if they were things in the world").

208. Cf. Schlag, Contradiction and Denial, 87 MrCH. L. Rev. 1216, 1220 (1989) ("Consciously, we all know that subject and object are not radically separate. Pre-consciously, however, we often use metaphors that succeed nonetheless in radically separating the two . . . .").

209. As Pierre Schlag warns, we are prone to "project such crude and primitive views of subject/object relations onto the texts of others" when they arc only "our own pre-conscious constructions." Id.

210. Michelman, supra note 96 , at $1503-04$.

211. Id. at 1503 .

212. Id. at 1503 n.36.

213. Id. at 1504 ("I do not know what is good for the soul. I do not lenow in what (if anything) personal freedom essentially consists. I do not know whether citizenship is a fundamental human good.").

214. Id.

215. Id. at 1513. 
consists of elements that a consciousness can identify, wield, and otherwise profess. What is salient about this subject is not that it is constituted by this fund, but that it draws on it. Although its tools may be limited by history, the subject's choice is nevertheless always already free. Thus, it is not surprising that Michelman describes republican politics as "all but indistimguishable" from Dworkin's conception of "law as the imstitutionalized form of self-consciousness on the part of community members about their situatedness in a common past, required by a conception of personal and political freedom that involves our contimuinig to be ourselves even as we reconsider what we are and ought to be about." ${ }^{\text {216 }}$ Who should we be today? Why, the best we can be, of course. ${ }^{217}$

It is instructive when someone as astute as Frank Michelman cannot talk about situatedness without, ultimately, eschewing it and thus undermining his own point. I would suggest that this phenomenon is itself a product of adversity and a testimony to the inertial hold of situatedness. Michelman, no less than others, is situated in a normative discourse that presupposes the traditional subject/object dichotomy. ${ }^{218}$ Accordingly, this dichotomy is constantly-and unconsciously-remscribed in his discourse.

Why does this matter? It matters for the same reasons that we have already encountered in the quandary of constitutional law in a conservative era. The homeostatic tendencies of all forms of thought tend toward reproduction of the status quo and against radical transformation. Attempts at transformative action cannot possibly be effective if they unconsciously reproduce the very context they are trying to transform. Thus, if we are to undertake the project of a constitutional pohtics, our first step must be to identify and reject the politics implicit im the traditional view of subject/object relations: the politics of the relatively autonomous subject.

The politics of the relatively autonomous subject is the politics of constitutional formalism. This subject is one that either constitutes its context or, at least, is free to overcome or transform it according to its desires (in essence, the neo-Kantian subject). It is the pohtics of late nineteenth-century "[d]emocratic optimism" which believed that as long

216. Id. at 1514 (emphasis added) (discussing R. DworkIN, supra note 4).

217. Of course, soinething is only "best" relative to an idealized model of what we think it shonld be. Thus, Dworkin's concept of law as integrity-in which one is obligated to make something "the best it can be," R. DworkIN, supra note 4, at 229-is necessarily indistinguishable from (and collapses back into) the cultural values that unconsciously animate the situated, constituted self. Moreover, as I liave explained elsewhere, Dworkin's concept is really only a dressed-up version of the cognitive phenomenon of prototype effects-that is, part of the basic cognitive process by which one configures new input in a manner that makes sense, to make it a colierent whole or a "best example" of an existing idealized cognitive model or reigning paradign. Winter, The Cognitive Dimension, supra note 12, at 2261-62 n.119.

218. See supra text accoinpanying notes 22-25. 
as "the rights of man are guaranteed, no liberty any longer encroaches on any other, and the co-existence of men as autonomous and reasonable subjects is assured." 219 It is the pohtics in which "formal equality" is sufficient to free the subjeet beeause context and situation do not effectively restrict outcomes. In slort, it is the politics of Lochner and its progeny.

The politics of the relatively autonomous subject is the world view in which each subject is free (im Justice Peckham's words) "to make contracts regarding labor upon sucli terms as they may think best,"220 regardless of context and situation. It is a world view in which there is nothing incongruous about simultaneously maintaining (in Justice O'Colmor's words) "that the sorry history of both private and public discrimination in this country has contributed to a lack of opportunities for black entrepreneurs,"221 and tliat "[t] $]$ here are numerous explanations for this deartll of minority participation, mcluding . . . both black and white career and entrepreneurial clioices."222 It is a world view in which "personal" riglits like the right to privacy are fully guaranteed without regard to the social, financial, and imstitutional conditions that would inake their attainınent even remotely plausible. ${ }^{223}$

It is, of course, an absurd world. It is a fairytale world in which we are always and already free, never constrained by context or situation. It is a world where the only cognizable constraints are those created by the clioices of otlier autonomous subjects, and they can always be controlled by the law (at least when those choices are unreasonable). ${ }^{224}$ And it is a dangerous world. ${ }^{225}$ It is dangerous not only because it is the world of retrogressive Justices, but also because it is the world unconsciously

219. M. MerLead-Ponty, Senśe ANd Non-SeNSE, supra note 21, at 102-03.

220. Lochner v. New York, 198 U.S. 45, 61 (1905); see also supra notes $73-78$ and accompanying text.

221. City of Richmond v. J.A. Croson Co., 488 U.S. 469, 499 (1989).

222. Id. at 503. But $c f$. Lou Reed, Dirty Blvd., (sound recording on the album NEW YoRK (Sire Records 1989)) ("no one here dreams of being a doctor or a lawyer or anything/they dream of dealing on the dirty boulevard").

223. See, e.g., Harris v. McRae, 448 U.S. 297, 316-17 (1980) (denial of federal funding for abortions for poor women does not violate equal protection); Maher v. Roe, 432 U.S. 464, 474 (1977) (equal protection clause does not require state that funds child birth for indigent woinen to fund abortions as well); see also Webster v. Reproductive Health Servs., 109 S. Ct. 3040, 3052 (1989) (" []$]$ is difficult to see how any procreational choice is burdened by the State's ban on the use of its facilities or employees for performing abortions.").

This is what Larry Tribe disparages as the "Newtonian" approach to reality. Tribe, supra note 96, at 14-17. "[W]hether by deploying carrots or by wielding sticks, as long as the state kecps its hands to itself, any change in social parameters simply constitutes a different menu of outcomes within which private citizens remain free to make their own choices." Id. at 17.

224. See Croson, 488 U.S. at 509 (The city can "tak[e] appropriate measures against those who discriminate," mcluding actions "to break down patterns of deliberate exclusion.") (emphasis added).

225. See Williams, The Obliging Shell: An Informal Essay on Formal Equal Opportunity, 87 
assumed by otherwise discerning legal academics who, we can be certain, oppose the outcomes of each and every one of the cases I have just noted. But, and we should be very clear on this, it is the only kind of world in which all one needs is a slightly better theory and everything can be made all right.

This partial theory-skepticism should not be mistaken for irrationalism, however. With Miclielman, I beheve that situated agents are nevertheless capable of acting from within a given eontext to transform it. Moreover, I believe that this transformative capacity is rationality (at least, properly understood). But before this situated-rationality can be properly understood, the full import of Michelman's description of dialogic politics must first be appreciated. All dialogue is situated in and dependent upon a constitutive nomos that is already given.

The nomos ... constitutes a world in which subjects find themselves; it is not a creation of individuals' subjective value choices. "This nomos is as much 'our world' as is the physical universe of mass, energy, and moinentum. . . . Our apprehension of the structure of the normative world is no less fundamental than our appreciation of the structure of the physical world." Subjects find theinselves in a world of meaning in just the same way that they find themselves in a world of space and time. ${ }^{226}$ Situatedness-including (as we shall see) the social constitution of the subject itself-is unavoidable.

\section{The Meaning of Situatedness}

The full implication of situatedness is easy to miss as long as one understands it solely as a matter of context or as an external precondition that inust be taken imto aceount. The problem with this still naive view is that it remscribes a distmction between the internal and the external, between the subject and its objects. ${ }^{227}$ To locate the subject within a social, cultural, and historical situation is to reestabhish that subject as an entity somehow separate from that situation.

Situatedness, therefore, must be understood as much inore than a

Mich. L. REV. 2128, 2142 (1989) ("So-called formal equal opportunity . . . misse[d] the heart of the problein. It put the vampire back in its coffin, but it was no silver stake.").

226. Kahn, supra note 157, at 57-58 (quoting and discussing Cover, supra note 178, at 5). This is one reason it cannot be that a "community talks itself into an historical identity." Id. at 3; see infra text accounpanying notes 273-92. The other reason is that "concrete events" play a role in "constituting what is ratioual." K. WHITESIDE, supra note 16, at 98.

227. See M. Merleau-Ponty, Phenomenology, supra note 18, at 362:

We inust therefore rediscover, after the natural world, the social world, not as an object or sum of objects, but as a permanent field or dimension of existence. . . . It is as false to place ourselves in society as an object among other objects, as it is to place society within ourselves as an object of thought, and in both eases the mistake hes in treating the social as an object. 
container in which the subject finds itself. ${ }^{228}$ Situatedness is, rather, a way of describing the epistemological ecology in which we are simultaneously constituting and constituted. We are constituting because meaning arises in the imaginative interaction of the human being with the environment. We are constituted because the situated quality of human existence means that both the physical and social environment with which we interact is already formed by the actions of those who have preceded us. For Merleau-Ponty, existential philosophy

tak[es] as [its] theme not only knowledge or consciousness understood as an activity which autonomously posits immanent and transparent objects but also existence, i.e., an activity given to itself im a natural and historical situation and as incapable of abstracting itself from that situation as it is of reducing itself to it.... The "subject" is no longer just the epistemological subject but is the human subject who ... thinks in terms of his situation, forms his categories in contact with his experience, and modifies this situation and this experience by the meaning he discovers in them. ${ }^{229}$

It is precisely in this double sense of "constitutional" as simultaneously constituted and constituting that we inust come to understand the situatedness of what Merleau-Ponty calls "the human subject." And it is in this double sense that we must consider this situated-subject and its role in "constitutional politics." 230 We are unavoidably constituted by the political actions of our predecessors and, at the same time, constitutimg througli our politics the world that our successors will inherit.

To understand the nature of the situated-subject, however, two things must be clear. First and foremost, the situated-subject is not sinple self-consciousness. That part of ourselves witl whicl1 we seem to have relatively direct contact, the part that seens self-present, is but the tip of the iceberg. Like the head that sits atop our bodies, it is but one part of an entire superstructure that makes consciousness possible. ${ }^{231}$

Second, the situated-subject is always already social. Like the "state of nature," the solitary subject is a theoretical construct impossible in the real world. No liuman infant could survive without the nurturance of

228. See Winter, Bull Durham, supra note 12, at 661-64, 681-84 (describing the limitations of the "container" metaphor).

229. M. Merleau-Ponty, SENSE AND NoN-SeNSE, supra note 21, at 133-34. But cf. M. MERLEAU-PONTY, SigNS, supra note 25, at 94 ("This snbject which experiences itself as constituted at the moinent it functions as constituting is iny body.").

230. Cf. L. Tribe, Constitutional Choices at vii (1985).

231. We have known as much since Sigmund Freud, although one would find very little in legal scholarship since Jeroine Frank that even attempts to take this insight seriously. Notable exceptions are Lawrence, The Id, the Ego, and Equal Protection: Reckoning With Unconscious Racism, 39 StAN. L. Rev. 317 (1987), and Comell, The Doubly-Prized World: Myth, Allegory and the Feminine, 75 CoRNELl L. REV. 644 (1990). 
other people; ${ }^{232}$ its earliest experiences already provide it with an entire repertoire of psychological mechanisms, defenses, complexes, and personality traits. The solitary subject is at best a hiterary device, ${ }^{233}$ at worst an oxymoron:

Solipsism is a "thought experiment"; the solus ipse [the self alone] a "constructed subject." This isolating method of thinking is intended more to reveal than to break the links of the intentional web. If we could break them in reality or simply in thought-if we could really cut the solus ipse off from others and from Nature [,] . . there would be fully preserved, in this fragment of the whole which alone was left, the references to the whole it is composed of. In short, we still would not have the solus ipse. ${ }^{234}$

What this means is that, because the subject is fashioned in its interaction with its pliysical and social world, it always already contains those relationships within it as the imaginative abstractions of those interactions. ${ }^{235}$

Both these points about the situated-subject are captured in the concept of sedimentation. Originating in the late writings of Husserl, the concept expresses the way meanings and assumptions build up within the subject and, once internalized, operate without the subject's conscious awareness. ${ }^{236}$ For example, Merleau-Ponty describes how embedded knowledge of both the physical and social world is used casually without reflection.

When I move about my house, I know without thinking about it that walking towards the bathroom means passing near the bedroom, that looking at the window means having the fireplace on $\mathrm{my}$ left, and in this small world each gesture, each perception is immediately located in relation to a great number of possible coordinates. When I chat with a friend whom I know well, each of [our] remarks ... contains, in addition to the meaning it carries for everybody else, a host of references ... without our needing to recall previous conversations with each other.... In the same way there is a 'world of thoughts', or a sediment left by our mental processes, which enables us to rely on our concepts and acquired judgments as we might on things there in front of us ... without there being

232. It is only in fictional and mythical contexts like the story of Tarzan or the legend of Romulus and Remus that infants can flourish without other humans, and even then some other species must fill the parental role.

233. See supra note 232.

234. M. MERleaU-PonTY, SigNS, supra note 25, at 173-74 (discussing Husserl) (footnotes omitted).

235. See, e.g., Winter, The Cognitive Dimension, supra note 12, at 2231-32 (discussing the unconscious elaboration of image-schemata).

236. E. Husserl, The Crisis of European Sciences and TRanscendental Phenomenology 52 (D. Carr trans. 1970) (referring to "the implications of meaning which are closed off through sedimentation or traditionalization, i.e., of the constant presuppositions of [our own] constructions, concepts, propositious, theories"). 
any need for us to resynthesize them. ${ }^{237}$

The process of sedimentation is a necessary adaptation without which consciousness would hardly be possible. With sedimentation, "[m]any actions are possible on a low level of attention," "opening the way for ninovations, which demand a higher level of attention."238

Sedimentation is the "deposit" of the subject's past interactions with its physical and social situation. It operates as a gestalt that, once integrated, can be invoked without being fully reactivated. ${ }^{239}$ Once a ineaning is sedimented, it can become self-reinforcing. ${ }^{240}$ Sedimentation is another way of describing the process by which we form, internalize, and then operate by means of idealized cognitive models. ${ }^{241}$

Sedimentation accounts both for intersubjectivity and for commumity. Because many subjects are situated in the same environinent, social experiences such as routine or habitual interactions between subjects give rise to inutual or reciprocal sedimentations. Through such sedimentations, shared social experiences develop into "institutions."242 Property is such an institution:

People routinely think of and treat material goods, whether personal arti-

237. M. Merleau-Ponty, Phenomenology, supra note 18, at 129-30 (emphasis added).

238. P. BERGER \& T. LUCKMANN, supra note 31, at 54; see also id. at $50-57$ (explaining the related process of "institutionalization," discussed at infra note 242 and accompanying text).

239. Merlcau-Ponty gives the example of communication of abstract meanings im philosophical discourse:

We begin reading a philosopher by giving the words he makes use of their "common" meaning; and httle by hittle ... his speech comes to dominate his language, and it is his use of words which ends up assigning them a new and characteristic signification. At this moment he has made himself understood and his signification has come to dwell in me.

... [F]rom this point on the preparatory stages of expression-the first pages of the book-are taken up again into the final meaning of the whole and are directly given as derivatives of that meaning, which is now installed in the culture. The way will be open for the speaking subject (and for others) to go straight to the whole. He will not need to reactivate the whole process; he will possess it eminently in its result. . . . Sedimentation occurs, and I shall be able to think farther.

M. MerleaU-PoNTY, SIGNS, supra note 25, at 91-92; accord E. HUSSERL, supra note 236, at 361.

240. See M. Merleau-Ponty, Phenomenology, supra note 18, at 441 ("[W]e must recognize a sort of sedimentation of our life: an attitude towarcs the world, when it has received frequent confirmation, aequires a favoured status for us.").

241. Building on earlier work with "frames" and "scripts," the concept of an idealized cogaritive model (ICM) was developed by George Lakoff to explain the structure of linguistic categories. $G$. LAKOFF, supra note 28, at 68-76, 145-72. As I have explained:

An ICM is a "folk" theory or cultural model that we create and use to orgarize our knowledge. It relates many concepts that are inferentially connected by means of a single conceptual structure that is experientially meaningful as a whole. For exanple, our understanding of the words "buy," "sell," "cost," "goods," "advertise," "credit," and the like, are made meaningful by an ICM of a commercial transaction that relates them together as a structured activity. The use of any of these words individually evokes the entire picture or model, the ICM-a sort of holistic, standardized account.

Winter, Transcendental Nonsense, supra note 12, at 1152-53 (footnote omitted) (emphasis in original); see also Winter, The Cognitive Dimension, supra note 12, at 2233-40.

242. P. BERGER \& T. LUCKMANN; supra note 31, at 51 ("Institutionalization occurs whenever there is a reciprocal typification of habitualized actions by types of actors."). 
cles, real estate, or capital, as owned by them. This conclusion is not merely abstract theory, but is bolstered and evidenced in everyday activities. Individuals in routine activity treat things as subject to the absolute control of particular persons, and such treatment is consistently validated by the reactions of others and the pragmatic usefulness of the treatment. ${ }^{243}$

In this way, a legal institution like property "is a social structure . . . which is a form of praxis, of living intersubjective relationships."244

The same process of sedimentation occurs witl respect to interactions of subjects witli the shared objects of a society. Thus, purely physical things form a master mold that helps shape individual situatedsubjects:

The spirit of a society is realized, transmitted, and perceived through the cultural objects which it bestows upon itself and in the midst of which it lives. It is there that the deposit of its practieal categories is built up, and these categories in turn suggest a way of being and thinking to men. ${ }^{245}$ Cultural objects are therefore much more than the furnishings of the community. By shaping the thought of those who use them, they motivate a way of life common to a particular group of people. What constitutes a community is the ineaning-saturated milieu that it creates for itself and that it transmits to its members. ${ }^{246}$

An obvious contemporary example is the automobile, which has shaped social attitudes in quite fundamental ways. For example, the car and the interstate highway systein have given us the particular contemporary configuration of our cities as a center business district rimged by higliways that provide access to suburbs and satellite work sites. ${ }^{247}$ This configuration in turn entails entire sets of values and lifestyle patterus characteristic of suburban or city living. ${ }^{248}$ But the impact of the

243. Van Zandt, supra note 199, at 924 (footnotes omitted); see also W. HAMRICK, supra note 17, at 43 ("In the social world, it is institutions ... that solidify this goal of equilibrium and cement the historical unity and identity of a society.").

244. W. HAMRICK, supra note 17, at 144. For Merleau-Ponty, "[t]lie profound philosophical meaning of the notion of praxis is to place us in an order which is not that of knowledge but rather that of communication, excliange, and association." M. MERLEAU-PoNTY, Dialectic, supra note 1, at 50. But in order properly to understand this explanation (that is, without losing the component of praxis that is action), it is miportant to recognize that, for Merleau-Ponty, "communication" is a crucial inetaphor: "[T]lie whole of nature is the setting of our own life, or our interlocutor in a sort of dialogue." M. Merleau-Ponty, Phenomenology, supra note 18, at 320 (empliasis added).

245. M. MERlEAU-PoNTY, SENSE AND NON-SENSE, supra note 21, at 131.

246. K. WhITESIDE, supra note 16, at 75 (emplasis in original). Although this insight is rare in legal scholarship, it is not absent altogether. See Binder, supra note 45, at 909.

247. In the nineteenth century, first the streetcar and then the urban railway had similar effects on the concentration of commercial activity in the center of town and the development of the first suburbs. D. SchuYler, The New URBan LANDSCAPE: The Redefinition of City Form IN NINETEENTH-CENTURY AMERICA 150-53 (1986).

248. See J. RaE, The American Automobile: A Brief History 239 (1965) ("The breakdown of rural isolation, the explosion of Suburbia, the construction of superhighways, the traffic congestion, the smog, the revision of social habit patterns, and the geometrical increase in 
automobile goes much deeper. Consider the television advertisement that advises the viewer to buy a particular make because: "It's not just your car; it's your freedom."

The upshot of sedimentation is that, one way or another, even the solus ipse already manifests "the references to the whole it is composed of." 249 Thus, the most important conclusion to be derived from the insight that we are situated beings is not that we are always already in a social context, but rather that the social is always already im us: "Society for man is not an accident he suffers but a dimension of his being. He is not im society as an object is im a box; rather, he assumes it by what is innermost im him."250 This is how, as Michelman says, the past can be "constitutively present in and for every self as language, culture, worldview, and political inemory."251

Sedimentation, however, is not stasis. ${ }^{252}$ Sedimentation is simultaneously conservative of past experience and an "imvitation to a sequel."253 Llewellyn artfully described this in his explanation of the Constitution as an ongomg institution that

generates attitudes not only of general and specific approval (in the main) of whatever happens to have become existing practice, but also attitudes

productivity resulting from the adoption of the assembly-line technique all came about because the automobile in the United States was seen as a commodity for general and multipurpose use, rather than as an itein of luxury."); see also R. Oldenburg, THE GREAT GoOd PLACE (1989). By emphasizing the automobile, I do not mean to suggest that it is an exclusive cause. Rather, it is the interplay of prior, related unaterial choices that shapes an entire form of life:

Though proclaimed as offering the best of both rural and urban life, the automobile suburb had the effect of fragmenting the individual's world. . . .

The typical suburban home is easy to leave behind as its occupants move to another. What people cherish most in them can be taken along in the move. There are no sad farewells at the local taverns or the corner store because there are no local taverns or corner stores. Indeed, there is often more encouragement to leave a given subdivision than to stay in it, for neither the homes nor the neighborhoods are equipped to see families or individuals through the cycle of life. Each is designated for families of particular sizes, incomes, and ages. There is little sense of place and even less opportunity to put down roots.

Id. at 4.

249. M. MerleaU-Ponty, Signs, supra note 25, at 174. At the level of ideas, the "prior deposit of normative references compos[es] the imprint of a people's history as a ... pohtical community." Michelınan, supra note 96, at 1517.

250. M. MERleau-PonTy, SENSE AND NON-SENSE, supra note 21, at 128-29; see Winter, Transcendental Nonsense, supra note 12, at 1135 ("[C]ulture is both ' $m$ ' us and that which we are embedded within.").

251. Miclielınan, supra note 96 , at 1513.

252. M. Merleau-Ponty, Phenomenology, supra note 18 , at 130 ('[T] he word 'sediment' sliould not lead us astray: this acquired knowledge is not an inert mass in the depths of our consciousness."). At this point, it is particularly important to be precise about the geological metaplior. Sediment is not bedrock, but the softer alluvial deposit of rivers and floods.

253. M. Merleau-Ponty, In Praise of Philosophy aNd OTHER EsSAYs 108-09 (J. Wild, J. Edie \& J. O'Neill trans. 1963) [hereinafter M. MERLEAU-PONTY, PhILOSOPHY] ("those events which sediment in me a meaning, not just as survivals or residues, but as the invitation to a sequel, the necessity of a future"). 
less capable of definition-sets, or built-up predispositions in the participants, to deal with situations those participants have previously never met or thought of, along the lines of the ways they know-so that in certain measure both direction and nature of new developments can be predicted ... 254

Sedimentation must, therefore, be understood as a twofold dynamic that is simultaneously backward- and forward-looking. The backward dimension of thought is one prominent source of adversity. ${ }^{255}$ The forward-looking dimension, the trajectories of growth and change, is what Merleau-Ponty refers to as "the advent of meaning."256

Advent, however, is not self-actuating; it must always be "taken up and developed by human imtentions."257 Thus, sedimentation plus advent does not equal determinism. Human rationality is a dynamic process of meaningful imteraction in and with an environment that is constantly in flux. Whatever our "built-up predispositions," we mevitably encounter situations that we "have previously never met or thought of."258 In this context, to react along the lines marked out by our sedimented knowledges is unavoidably to act imaginatively in a new circumstance, reasoning in terms of a known one. Thus, the subject is neither

254. Llewellyn, supra note 65 , at 27 (emphasis in original). Thus, sedimentation is backwardlooking in precisely the way that Llewellyn identified in cormection with institutions. "An institution is in first instance a set of ways of living and doing. It is not, in first instance, a matter of words." Id. at 17 (einphasis in original). Moreover,

it is action which coines first, to be followed by delayed perception of that action, then by rationalization of the action delayed still longer, and finally by conscious normatization of what has been perceived or rationalized. Before these latter processes have been worked out, the lines of the action commonly have shifted. [Thorstein] Veblen's eyes were kecn: "A inan's ethics are modelled on the conditions of his grandfather's time."

Id. at 17 n.30; cf. P. BERGER \& T. LUCKMANN, supra note 31, at 64-70.

255. Cf. K. MARX, THE EighteENTH BRUMAIRE of Lovis Bonaparte 15 (1963):

Men inake tleir own history, but they do not make it just as they please; they do not inake it umder circumstances chosen by themselves, but under circumstances directly encountered, given and transinitted from the past. The tradition of all the dead generations weighs like a nightmare on the brain of the living. And just when they seein engaged in revolutionizing themselves and things, in creating something that has never yet existed, precisely in sucl periods of revolutionary crisis they anxiously conjure up the spirits of the past to their service....

As Merleau-Ponty uses the term "adversity," it appears to refer to more than one phenoinenon. He also invokes an "indeterminate adversity without intention or law." M. MERLEAU-PONTY, DIALECTIC, supra note 1, at $38 \mathrm{n} .11$. Used in this sense, adversity is a resnlt of contingency: "the idea of a fundamental element of chance in history." M. MERIEAU-PONTY, SIGNS, supra note 25, at 218; see K. WHITESIDE, supra note 16, at 266-67 (criticizing Merleau-Ponty for not differentiating and defining the forms of adversity that obstruct social and revolutionary inovements).

256. M. MerleaU-PonTY, Dialectic, supra note 1 , at 17 (" $[\mathrm{H}]$ istory does not work according to a model; it is, in fact, the advent of meaning."). Merleau-Ponty borrowed the term "advent" from Paul Ricoeur. M. MERLEAU-PoNTY, SIGNS, supra note 25, at $68 \mathrm{n} .26$ (referring to P. Ricoeur, Onectivity AND SUBnectivity IN History AND TrUTH 36 (C. Kelbley trans. 1965)).

257. M. MerleaU-Ponty, Dialectic, supra note 1 , at 18.

258. Llewellyn, supra note 65 , at 27. 
autonoinous in its ability to transform its context nor determined by the objects of its past introjections. ${ }^{259}$

From an ex ante perspective, then, advent is necessarily plural. At the same time, meaning is not indeterminate. Our situatedness constrains us: We do have choices, but they are not infinite. Only some possibilities will flow from a given history; other trajectories will be blocked by the adversity of the sedimented past we carry inside us. ${ }^{260}$ Which is to say that advent and adversity are two sides of the same coin. This is what I have described as "nondeterminacy"--that is, the "sense that huunanly constructed meanings are not determinate, but are nevertheless framed and constramed by the systeinatic nature of the cognitive process."261

In the next Section, I will consider sone of the imphications of these related phenoinena of sedimentation, adversity, and nondeterminate advent. At this point, however, it is important to recognize that these phenomena are frequent and familiar experiences for those who work with legal doctrine. 262 Maitland's famous dictuin- "[t]he forms of action we have buried, but they still rule us from their graves"263 -is perhaps the best-known recognition in legal scholarship of adversity in legal doctrine. Less well-known is how the writ system, as sedimented in the private rights inodel, contimues to shape inoderu standing doctrine. ${ }^{264}$ By the same token (since it is the same coin), standing doctrine is also one of the most stunning exainples of advent understood as the way existing possibilities of ineaning are taken up and developed by human intentions. As I have chroincled, the constitutional doctrime of standing was fashioned by Justices Brandeis and Frankfurter froin unrelated equity doctrines in order to effectuate jurisdictional limitations on a Court whose substantive imitiatives they opposed. ${ }^{265}$

259. See M. MERIEAU-PONTY, SENSE AND NON-SENSE, supra note 21, at 134 (The subject is "as incapable of abstracting itself from that situation as it is of reducing itself to it.").

260. See M. MERLEAu-PonTy, Philosophy, supra note 253, at 112 ("Now this working of the past against the present does not culminate in a closed universal history or a coinplete system of all the possible human coinbinations . . . . Rather, it produces a table of diverse, complex probabilities, always bound to local circumstances [and] weighted with a coefficient of facticity ....").

261. Winter, The Cognitive Dimension, supra note 12, at 2245.

262. For examples of adversity in legal doctrine, see Fischl, Self, Others, and.Section 7: Mutualism and Protected Protest Activities Under the National Labor Relations Act, 89 CoLUM. L. REV. 789, 844-58, 861-62 (1989) (in interpreting remedial labor legislation, courts and lawyers continue to rephicate the very set of assumptions about self-interested action that the statute was designed to overturn); Sunstem, Constitutionalism After the New Deal, 101 HARv. L. REV. 421, 475 (1987) ("The New Deal was largely a response to a perception that the cominon law catalog of rights was underinclusive. It is an iromic fact that for the first generation after the New Deal, the judicial role remained rooted in the common law ... . "); id. at 502 ("Notwithstanding this understanding, pre-New Deal conceptions of legal rights perineate modern public law.").

263. F. Martland, Equity: Also the Forms of Action at Common law 296 (1909).

264. See Wimter, The Metaphor of Standing, supra note 12, at 1376-78, 1388-91, 1475-78.

265. Id. at 1440-51, 1454-57. 
Metaphors frequently operate as the mechanisms of imagination that mark out trajectories for the advent of meaning. ${ }^{266}$ The advent of standing doctrine was marked out, in part, by the already prevalent use of the metaphor "a standing in court." 267 Although the original usage was a reference to the litigant's entitlement to an injunction (and thus a question of the merits), ${ }^{268}$ the phrase is redolent of jurisdictional considerations (to have no standing in court is to be someone who cannot be heard by the judge). Other examples for which I have provided detailed accounts include Justice Holmes' reconstruction of conventional metaphors for mind and ideas im the "marketplace of ideas" metaphor ${ }^{269}$ and Chief Justice Hughes' skillful refashioning of the "stream of commerce" metaphor in $N L R B$ v. Jones \& Laughlin. 270

In each of these instances, moreover, the advent of constitutional ineaning was also dependent on mucli wider cultural developments such as the ascendancy of laissez-faire in the late nineteenth century ${ }^{271}$ and the political and economic exigencies of the Great Depression, ${ }^{272}$ respectively. Each of these opimions, therefore, illustrates the situated, dynamic, inultidimensional process by which ineaning is constituted. Meaning is not simply the product of social coherence or pure subjectivity: The elaboration of meaning is simultaneously the product of past

266. Winter, Transcendental Nonsense, supra note 12, at 1183 ("[T] he available metaphors conventional in the culture both create and constrain the possible extensions of the available inodels."). For a fuller discussion of the cognitive means by which inodels are elaborated and extended, see G. LAKOFF, supra note 28, at 91-112 (development of radial categories); id. at 104-09 (chairring in linguistic category); id. at 77-80 (role of metonymies in developing new meanings); id. at 419-44 (chaining and transformation of image-scheinata in the elaboration of the linguistic category defined by the polysemous uses of the preposition "over").

267. See, e.g., Debs v. United States, 158 U.S. 564, 584 (1895); Florida v. Anderson, 91 U.S. 667, 675 (1876); Ritehie v. Franklin County, 89 U.S. (22 Wall.) 67, 77 (1874). These cases and their relationship to modern standing doctrine are discussed in Winter, The Metaphor of Standing, supra note 12, at 1418-25, 1437-38. The role of the metaphor, however, is only one part of a complex story of doctrinal developinent that is carefully traced in $i d$. at 1417-57.

268. This was true as late as 1926. See General Inv. Co. v. New York Cent. R.R., 271 U.S. 228, 230-31 (1926) ("Whether a plaintiff seeking such [equitable] rehief has the requisite standing is a question going to the merits, and its determination is an exercise of jurisdiction. If it be resolved against him, the appropriate deeree is a dismissal for want of merits, not for want of jurisdiction.") (citations omitted).

269. Abrams v. Uinited States, 250 U.S. 616, 630 (1919) (Holmes, J., dissenting); see also Winter, Transcendental Nonsense, supra note 12, at 1188-91.

270. 301 U.S. 1 (1937); see also Winter, Transcendental Nonsense, supra note 12, at 1199-206.

In Jones \& Laughlin, Hughes reorganized the cognitive model for interstate commerce issues. In doing so, he did not operate free-form, as a subjeetivist might have it. Rather, he worked with the metaphoric material already in the cases to refashion commerce clause doctrine in a manner that was neither predetermined by the materials nor coinpletely arbitrary.

Id. at 1199.

271. Winter, Transcendental Nonsense, supra note 12, at 1186-90.

272. See supra text accoinpanying notes 117-18. 
sedimentation, current human intentions, and larger cultural contexts that support its advent.

\section{Constitutional Politics}

An effective constitutional pohtics must take into account the sedimented cultural context in which we are unavoidably situated. Strategic transformative action is nevertheless possible because reflection is possible. ${ }^{273}$ But to be effective, that reflection inust simultaneously be teinpered by an appreciation of adversity and nurtured by an understanding of its transformative capacities. "The choice which we make of our life is always based on a certain giveımess. My freedoin can draw life away froin its spontaneous course, but only by a series of unobtrusive deflections which necessitate first of all following its course-not by any absolute creation."274 This lesson is difficult, in part because it seems to run significantly counter to the Enlightenment-bred, "normative selfunderstanding of deinocracies that public decisions are reached by autonoinous . . . citizens in a process of unconstrained exchange of opimion."275 But this lesson of constraint is an important one for, "without the roots which it thrusts into the world, it would not be freedom at all."276

I explore these insights in the subsections that follow. Much current legal theory champions dialogue and "commumicative practice" as a transformative methodology. I question this dialogic strategy in the first subsection, testing it agamst the constraining effects of sedimentation and contrasting its efficacy with that of committed action. In the second, I elaborate a rolc for legal scholarship—clearly, a form of dialogue-when it is practiced as situated reflection. Only then, in Part V, will we be positioned to atteinpt a meaningful dialogue concerning the imphications of situatedness and its potential as a catalyst for the advent of new constitutional ineanings.

\section{Normative Dialogue and Transformative Action}

Because we are not autonomous consciousnesses free of all prior commitments, we cannot be as uninhibited in our ability to sift our context for transformative possibilities as Michelman would hike. We can choose to look to the margins; indeed, we should. But the problem remams that what we are most likely to see is that which conforms to our own, already sedimented perspective.

273. See Winter, Bull Durham, supra note 12, at $681-91$ (discussing "situated selfconsciousness").

274. M. Merlead-Ponty, Phenomenology, supra note 18, at 455.

275. S. BENHABIB, Critique, NORM, AND UTOPIA 283 (1986), quoted in Michelman, supra note 96 , at 1502 n.30.

276. M. Merlead-Ponty, Phenomenology, supra note 18, at 456. 
[I]t is inevitable that the characteristics of our own worldviews, decentered and reflexive as they are, will come into play. To understand is to understand in a certain context . . . . We cannot divest ourselves of the constituents of our culture at will or by an act of fiat; they are the ones we bring to bear on the analysis of any situation. ${ }^{277}$

It is only a conceit of consciousness- - "the forgetfulness in the presumption of rational mind to complete cultural autonomy"278 _ which leads us to think that our choices are basically free and intentional.

This means, however, that normative dialogue cannot suffice as a modality of transformation. ${ }^{279}$ Just as much of the legal and political work of constitutional decisionmaking is being done at the epistemic level, so too does most of the work of persuasion occur well below the surface of dialogue. In the end, what matters inost is not one's conscious willingness to be persuaded by good faith arguments, but rather the unconscious standards or animating structures by which one understands an argument as persuasive. ${ }^{280}$

This poimt can be illustrated with the following hypothetical. Consider a good faith normative dialogue about the use of coercive criminal sanctions for racist and misogymist speech. One participant is a committed civil hibertarian, the other a dedicated feminist. Both of the participants simcerely declare that they are open to argument and persuasion. Yet they disagree on basic issues: whether suppression of speech or subordination of women is the greater evil, whether the chosen means exact too high a cost, and so on. By what rational, normative arguments will each be brought to appreciate the weight that the other places on her values? The very depth of each participant's conviction will be reflected in the correspondingly high burden of persuasion she imposes on the other's argument. ${ }^{281}$

This example may not seein much like opemiess to persuasion, or even very much like argument. But it is only a stronger version of what we do at all times, even when we are open to persuasion.

When we hear an argument ..., [w] think "that's not what we should want out of life, that's not what the world is like" and dismiss it out of hand ("that can't be true"). Or we think "yes, that's right, that's the way

277. S. BENHABIB, supra note 275 , at 272 .

278. J. O'NEILL, supra note 16, at 4.

279. Cf. Van Zandt, supra note 199, at 927 ("[C]hange rarely occurs from consciousness-raising or from appeals of rational moral persuasion ... . This is because the individual's sense of social order . . . is a grounded 'rational' sense."); see also supra text accompanying notes 135 \& 185 .

280. See Michelman, Possession vs. Distribution in the Constitutional Idea of Property, 72 IowA L. REV. 1319, 1325 (1987) ("Ultimate consensus on important matters of public policy is not [i]n the cards, even among citizens entering in good faith into mutual civic dialogue.").

281. Cf. A. MAcINTYRE, AFTER VIRTUE 7-19 (2d ed. 1984) (ascribing the incommensurability of much conteinporary moral argument to the loss of the sliared tradition in which the terns "of inoral argunent were formerly grounded). 
it is" and accept it (sometimes feeling we had already beheved the argument before we heard it). ${ }^{282}$

We necessarily evaluate arguments and information in terms of soine set of unconscious assumptions, beliefs, standards, frames of reference, and the like. ${ }^{283}$ As long as participants in dialogue reinam unself-conscious, they will be unaware of these animating structures and their vulnerability to persuasion will be severely limited.

This is not to say that meaningful dialogue can never take place. Persuasion will be possible to the extent that tlie participants are situated in soine common matrix or sliared assumptions to wlincli they both can refer. ${ }^{284}$ In tlie case of normative argument, a participant may be persuaded by an argument that appeals to some other assumption or belief slie already lolds. But transformative dialogue cannot overcoine incommensurables witlout a ineans for inore radical conversion.

Some alternative means exist. A skillful narrative may bring one to compreliend another's experience or perspective, perliaps effectuating a normative "gestalt switcli" or perhaps just clianging one's appreciation of the stakes. ${ }^{285}$ But, even so, one will unreflectively evaluate tliese arguinents and narratives in terms of one's already sedimented assumptions and beliefs. Thus, as long as one's partner im dialogue remains unselfconscious, ler very perceptions of trutli or falsity as well as ler evaluations of what is compelling or unpersuasive will be determined unreflectively by these preexistimg understandings.

The problem with prescriptions for more and better normative dialogue is precisely that they ignore this cogintive level, the underlying stratum at wlicli inost of the work is done. These prescriptions necessarily presuppose the relatively autonomous subject, magically capable of transcending lier own limitations witl a single, rationalist bound. For 39.

282. Frug, Argument As Character, 40 STAN. L. REV. 869, 920-21 (1988); see also supra note

283. The nomenclature is immaterial. The critical point is, as argued by Stanley Fish, that there is no clear space to stand; these unconscious structures are the very condition of consciousness. See, eg., S. FisH, supra note 36, at 459; see also Moore, Trial by Schema: Cognitive Filters in the Courtroom, 37 UCLA L. REV. 273 (1989) (discussing the role of cognitive schemas in jury decisionmaking).

284. Michelman recognizes this point: "The persuasive character of the process depends on the normative efficacy of some context that is everyone's-of the past that is constitutively present in and for every self as language, culture, worldview, and political memory." Michelman, supra note 96, at 1513 (emphasis im original). For further development of this point, see my Contingency and Community in Normative Practice, 139 U. PA. L. REV. 965 (1991).

285. In The Cognitive Dimension, supra note 12, at 2271-79, I describe how storytelling works either by appealing to assumptions already held by the audience or by bringing the audienee to undergo vicariously in its inagination the experiences of the protagonist. In the latter case, there can be truly transformative argument. See id. at 2277-79. But note that the work of persuasion issues not im a narrowly conceived practice of reason-giving, but rather in an imaginative act of empathy. Another modality is a task-centered approach that seeks to reeonstitute group identification around a common goal. See infra text accompanying notes 300-01. 
proponents of normative dialogue, the key to success lies in the subject's openness to persuasion and her willinguess consciously to set aside her own values in order to consider the perspectives of others. ${ }^{286}$ This is a noble vision, but one that is fundamentally flawed.

The most powerful determinants of belief are not idealistic constructions in the form of personal projections that need to be opened to the different perspectives of others. Rather, the most powerful determinants are those embodied in the social interactions that give rise to the situatedsubject's acquisition of cultural "truth." Because the resulting assumptions and beliefs are internalized as the very grounds of consciousness, they are largely imperceptible to the conscious subject: These conceptualizations are transparent in the sense that they act as an invisible cognitive filter through which the subject sees the social world. ${ }^{287}$ As long as the subject remains unreflective, this transparency will project the mutual entailment of the epistemic and the political in a way that will be experienced as "objective." In contrast, minority views will seem merely perspectival rather than "true."288

Thus, widely shared, internalized assumptions and beliefs are difficult to overcome precisely because they are more than simply dominant ideas open to conscious, intellectual reconstruction. They are difficult to overcoine because they are einbodied in and constantly reinforced by the sedimented social field of public interactions, cultural objects, and common experiences-"the meaning-saturated milieu"289 in which we are always already situated. If the resulting sedimentations are to be overcome, it will be ouly because we have acted to transform that social field directly.

From this perspective, the naive faith in normative dialogue as a means to accomplish change begins to look like nothing so inuch as faith in a "talking cure." But it is only the most vulgar nnderstanding of psychoanalysis that thinks one can solve deep-seated personal problems solely by introspection. Reflection is, rather, an experiential process. It assumes a given situation, but it inust work itself out in a new one. ${ }^{290}$ So,

286. Because rationalist consciousness views all other selves as capable of the same intellection, at least in theory, the rationalist assuines that reasoned dehberation must govern all interpersonal enterprises. If all parties conduct this deliberation in good faith, the better argument will necessarily win the day. If the better argument does not prevail, it can only be because some of the parties have chosen to be disingenuous, dishonest, or fraudulent, or because they still do not understand the rules of the game.

Schlag, supra uote 176, at 1211 (emphasis in original) (footnote omitted).

287. For an explanation of these terms and their derivation from widely shared metaphoric understandings, sec Winter, Bull Durham, supra note 12, at 682-86.

288. See supra text accompanying note 39.

289. K. WHITESIDE, supra note 16 , at 75 .

290. By taking up a present, I draw together and transforn iny past, altering its significance, freemg and detaching myself from it. But I do so only by committing myself somewhere else. Psychoanalytical treatment does not bring about its cure by producing 
too, an effective constitutional politics cannot be waged solely at the level of theory, of normative dialogue, or even of legislation. ${ }^{291}$ It must first germinate in action and then take root in the forms of life tliat are necessary to ground each-theory, dialogue, or legislation-as an expression of ineaning.

Real cliange coines through committed action. In both senses of the term, constitutional meaning begins in the grounded cognitive process by which we translate social experience into cultural meaning. Like all meaning, law is grounded in a form of life; it is the entirely contingent product of wider social practices and understandings. Accordingly, a truly transformative constitutional politics inust be sustained by lived human experience and committed social action. ${ }^{292}$ Radical transformation is only possible within the context of committed social movements or wholesale social ferment like the civil rights movement or the New Deal.

In contrast to the rigors of a truly transformative constitutional politics, consider the law's naive response to the historical entrenchinent of racisin in America. We prohibit it, as if "it" were an identifiable thing leld in consciousness that could easily be ascertained and just as easily bainshed. But, as Charles Lawrence has thoughtfully argued, the intent standard inakes no sense whatsoever if one understands racism as a matter of deeply sedimented, socially produced "tacit understandings" and "cultural stereotypes."293 To define as discriminatory only those acts accoinpained by conscious intent is to reinove only the fruit of the poisonous tree, leaving the roots, the trunk, and the branches all intact.

direct awareness of the past, but in the first place by binding the subject to his doctor through new existential relationships. It is . . . a inatter of reliving this or that as significant, and this the patient succeeds in doing only by seeing his past in the perspective of his co-existence with the doctor. . . . The same applies in all cases of coining to awareness: they are real only if they are sustained by a new colnmitment.

M. Merleau-Ponty, Phenomenology, supra note 18, at 455; see also Schön, Generative Metaphor: A Perspective on Problem-Setting in Social Policy, in MeTAPHOR AND Thought 254, 277 (A. Ortony ed. 1979) ("II]t is significant that the participants are involved in a particular concrete situation; at the same time that they are reflecting on the problein, they are experiencing the phenomenon of the problem.") (describing problem-solving in industrial research).

291. See West, Progressive and Conservative Constitutionalism, 88 MiCH. L. REv. 641, 717-21 (1990) [hereinafter West, Constitutionalism]. West exhorts us to redirect progressive constitutionalism toward the legislative process. In a dramatic conelusion, however, she recognizes that her program fatally lacks grounding in our current social context: "The key, of course, is to create a progressive Congress, and behind it a progressive citizenry. We presently have neither, to put it lightly." Id. at 721 . And so, with stunning alacrity, she has already retreated from the suggestion that we can rely on civic-minded legislators to vindicate individual and ininority rights. See West, The Supreme Court 1989 Term-Foreword: Taking Freedom Seriously, 104 HARV. L. REV. 43, 62 (1990).

292. In Transcendental Nonsense, supra note 12, at $1224-33$, I provide a more extended version of this argument that explains the grounding of legal rights in social experience. I return to this idea in the next Section. See infra text accompanying notes 361-70, 381-83, 409-18 \& 501-02.

293. Lawrence, supra note 231 , at 323. 
Because the law considers only relatively autonomous subjects and their intentional actions, it is entirely blind to the ways in which social assumptions about race are already sedimented in the unconscious. ${ }^{294}$ As a result, most of the influence of racial prejudice on individual and social action is obscured. Worse yet, it is sanitized: "[R]acially prejudiced behavior that is actually the product of learned cultural preferences is experienced as a reflection of rational deduction from objective observation, which is nonprejudicial behavior."295

Once we understand racism as a function of sedimented social practices and perceptions, the nature of the legal landscape changes dramatically. Consider the Civil Rights. Act of 1875,296 the Reconstruction statute struck down by the Supreme Court in the Civil Rights Cases 297 and vindicated as constitutional by later Warren Court decisions. ${ }^{298}$ In providing for the integration of all public facilities including inns, taverns, and theaters, the drafters understood that any real attempt to amehorate the problem of race must begin at the level of day-to-day experience. ${ }^{299}$ Studies in the social sciences have repeatedly shown that the most effective way to overcome racial prejudice is to bring together interracial groups under conditions of equality and involve them in sustained work on a common task. ${ }^{300}$ It is positive experience of the Other-rather than being told to respect the Other or learning about the Other-that is the most powerful persuasion of all. One can only begin to imagine how the law might look-on affirmative action or in providing

294. See id. at 322 ("We do not recognize the ways in which our cultural experience has influenced our beliefs about race or the occasions on which those beliefs affect our actions.").

295. Id. at 339; see also Frecman, Legitimizing Racial Discrimination Through Antidiscrimination Law: A Critical Review of Supreme Court Doctrine, 62 MiNN. L. REv. 1049, 1052-57 (1978).

296. 18 Stat. 335, 336 (1875) (sections 1 and 2 declared unconstitutional; sections 3 and 4 repealed (1948); section 5 omitted as obsolete).

297. 109 U.S. 3 (1883).

298. See Jones v. Alfred H. Mayer Co., 392 U.S. 409 (1968); United States v. Guest, 383 U.S. 745 (1966); Katzenbach v. McClung, 379 U.S. 294 (1964); Heart of Atlanta Motel v. United States, 379 U.S. 241 (1964).

299. The original draft of the statute would have included churches and cenneteries as well, but this was too controversial and was not included in the final bill. For an exploration of the assumptions about the social and the personal that animated the proponents of this statute, sec Gudridge, Privileges and Permissions: The Civil Rights Act of 1875, 8 LAW \& PHIL. 83 (1989).

300. See Amir, The Role of Intergroup Contact in Change of Prejudice and Ethnic Relations, in TOWARDS THE Elimination OF RACISM 245 (P. Katz ed. 1976); Cook, Cooperative Interaction in Multiethnic Contexts, in Groups in Contact: The Psychology of Desegregation 155 (N. Miller \& B. Brewer eds. 1984); Cook, Experimenting on Social lssues: The Case of School Desegregation, 40 AM. PSYCHOLOGIST 452 (1985); Gaertner \& Dovido, Prejudice, Discrimination, and Racism: Problems, Progress, and Promise, in Prejudice, Discrimination, and Racism 315, 318-19 (J. Dovido \& S. Gaertner eds. 1986); Slavin \& Madden, School Practices That Improve Social Relations, 16 AM. EDUC. RES. J. 169 (1979). Much of this work builds on the "contact hypothesis" articulated by Gordon Allport in his classic work. G. ALLPORT, THE NATURE OF PrejUDice 26181 (1954). 
reinedies in school and einployment cases-if the equal protection clause were read as pointing to an associational imperative ${ }^{301}$ rather than as an invitation to judicial mind-reading or a quest for a chimerical statistical parity.

And yet, that being said, the contrast between the hostile judicial reaction to the Reconstruction statute and the judicial acceptance of its more recent counterparts illustrates what it really takes to accomphish change. Michelman describes the legal developments of the 1950s and 1960 s as a process in which, "the judicial agents of the challengers' accumulating citizenship drew on interpretive possibilities that the challengers' own activity was helping to create." ${ }^{\text {302 }}$ Surely so. But just as surely, this understates the case. To recognize these "generative indeterminacies" as "products of action, the creations of motivated acts of perception and cultivation," 303 is to ignore the dogs, the hoses, the tear gas, the billy clubs, the bullets, and the guns. It is to ignore the quite literal way in which the actions of the civil rights protesters said: "We do inean this in the medium of blood' (or in the medium of time in jail); 'our lives constitute the bridges between the reality of present official declarations of law and the vision of our law triumphant." "304

There is nothing inetaphoric about Cover's invocation of the constitutive impact of violence, as I was reminded quite dramatically when I quoted this passage not long ago at Michigan's "Legal Storytelling" symposium. ${ }^{305}$ Afterward, one of tlie participants shared with ine a poignant personal vignette. "When I was a child," slie said, "my parents took me with them to a civil rights demonstration. I still remember the hatred and seething violence in the faces of those on the streets as we rode by with the other protesters. It was palpable. I never understood how my parents could liave risked a child's safety in that way. A child. I resented it. But this afternoon, when you mentioned Cover's point about 'the medium of blood,' I understood that my parents were right. It was necessary."306

\section{The Role of Scholarship}

I have argned that the transformative potential of constitutional politics resides in the kind of collective actions that are capable of constituting a form of life. But I do not inean to suggest that there is no meaningful role for the legal scholar. The social is not merely an external state

301. See infra text accompanying notes 481-91 \& 503-22.

302. Michelman, supra note 96 , at 1530 .

303. Id. at 1529 (emphasis added).

304. Cover, supra note 178, at 47 (emphasis changed from original).

305. Symposium: Legal Storytelling, 87 Mich. L. REv. 2073 (1989).

306. I am grateful to Professor Mari Matsuda for allowing me to retell her story. 
of affairs in which we are situated like an object in a box; it is inaintained equally by what is internalized in us. These internalizations are amenable to reflection, and that reflection can be harnessed to facilitate change.

Instead of seeking to transform the world with a better theory, the situated scholar engages in what I have identified as "theory with a small-t."307 This kind of theory does not seek a determinate formula to govern practice. Rather, it begins with the exploration of the larger cultural constructs and stabilized inatrices in which lawyers, judges, and laypersons are always already situated. ${ }^{308}$ From there, it seeks out the ways those constructions are sedimented in the legal mind. Its goal is to unearth the underlying cultural models that animate legal doctrine and structure judicial decisionmaking. ${ }^{309}$

When successful, this form of theory is capable of exposing the inner inechanisms by which the pohtical and the epistemic in legal doctrine are mutually entailed. For example, the individualist and merits-neutral, process orientations that characterize modern standing doctrine are not simply the products of pohitical or ideological choices. Rather, they are antecedent entailments of the "standing" metaphor itself and, together with the kinds of social institutions discussed above, the ontological effects of sedimented ways of thinking. ${ }^{310}$ Similarly, the first amendment cases that protect corporate speech and wealthy supporters of pohtical campaigns $^{311}$ are not mere manipulations in favor of the powerful. They are also direct reflections of a first amendinent that is itself conceptualized in market terms. ${ }^{312}$

The methodology of this project is not deductive logic, but what I

307. Winter, Bull Durham, supra note 12, at 644-45, 690-91.

308. Jan Deutsch issued this call sone time ago, citing the need

to examine the origins and content of the community agenda that defines the conditions for group interaction, and the degree to which that agenda has been internalized by participants in such interaction. Potential groups simply represent potential changes in the community agenda, and an adequate account of their crystallization therefore crucially involves a description of the psychological mechanisms in terms of which changes are introduced into individuals' perceptions of the norms and goals of the society in which they live, the roles they are to play within that society, and the constraints society has imposed upon those roles.

Deutsch, supra note 106, at 259.

309. Winter, Bull Durham, supra note 12 , at $690-91$.

310. On the individualist entailment, see Winter, The Metaphor of Standing, supra note 12, at 1387-88 ("In the inetaphorically structured reality of the law of standing, there are no forests and no ecosystems. There are only trees; and only the trees have 'standing.' "). On the process entailment, see id. at 1388-91, and supra text accompanying notes 267-68.

311. See, e.g., Central Hudson Gas \& Elec. Corp. v. Public Serv. Comm'n, 447 U.S. 557 (1980); First Nat'l Bank v. Bellotti, 435 U.S. 765 (1978); Buckley v. Valeo, 424 U.S. 1 (1976); cf. Virginia State Bd. of Pharmacy v. Virginia Citizens Consumer Council, Inc., 425 U.S. 748 (1976).

312. Winter, Transcendental Nonsense, supra note 12, at 1194-95 ("[T] he protections afforded wealth by current first amendmeut doctrine may be part of the interest that accrues to the wealthy in a society that values wealth and power and invokes them as the source domain for potent cultural inodels and inetaphors."); see also Michelman, supra note 280, at 1340-50 (emphasizing the role of 
have called "situated self-consciousness." 313 Situated self-consciousness seeks to uncover the stops and pedals of our intcrnal constructions. Situated self-consciousness is the reflective capacity to reveal what MerleauPonty calls "the links of the intentional web." 314 "[I]t involves the capacity to unravel or trace back the strands by which our constructions weave our world together. Although we may be situated in a web of belief, there is nothing that prevents us from making those behefs translucent and, thus, amenable to reflection." 315 Situated self-consciousness is the imaginative, reflective process through which the transparent conceptualizations that unconsciously structure legal decisionmaking can be recognized and laid bare. It is a method for unveiling our most basic criteria of choice.

Situated self-consciousness is not, however, a ineans by which to achieve soine spontaneous freedom to reconstruct the social world. To the contrary, the potential yield of situated self-consciousness is rather more like a topographic inap of the sedimented social field in which transformative efforts necessarily take place. ${ }^{316}$ Consider, however, how useful such a "map" would be to legal advocates. To the extent that it accurately charts the lines of advent and roadblocks of adversity, this "map" would be a sketch that distimguishes between arguments that are merely plausible and those that are likely to be persuasive. Indeed, it is in just this way that legal theory can best inform legal practice.

For those concerned with social change, such a "map" would at the very least alert us to the topology of adversity that constrams transformative attempts. Armed with such a "inap," one might begin ineaningfully to explore lines of advent that could usefully be pursued: the potential elaborations and transformations of the culture's existing models and metaphors that provide the possible trajectories of change. Armed with such a "map," one might begin to understand the processes that (to marry Merleau-Ponty to Kuhn) might be characterized as normal advent. In short, one might begin to understand the ordinary workings of the imagination that, in our ignorance, are mysteriously attributed to the "strong poet" or "creative genius."

A second task for theory with a small-t would be to develop new paradigins and useful generalizations that could serve as springboards for

the formal, possessive dimension of the property concept at work in these cases); Tushnet, Corporations and Free Speech, in THE Politics OF LAW, supra note 153, at 253-55 ("money talks").

313. Winter, Bull Durham, supra note 12, at 685-86.

314. M. Merleau-PontY, Signs, supra note 25 , at 173, quoted in full at supra text accompanying note 234.

315. Winter, Bull Durham, supra note 12, at 685-86 (emphasis in original) (footnotes omitted).

316. Cf. M. MERLEAU-PONTY, DiALECTIC, supra note 1, at 199 ("Like perceived things, my tasks are presented to ine, not as objects or ends, but as reliefs and configurations, that is to say, in the landscape of praxis."). 
more comprehensive change. Examples within the canon of legal scholarship might include Charles Reich's classic, The New Property, ${ }^{317}$ and Abram Chayes' groundbreaking article, The Role of the Judge in Public Law Litigation. ${ }^{318}$ This is what we might call revolutionary advent, and it is a task requiring more than ordinary imagination. It may involve, as in the former case, the radical reconceptualization of an existing legal concept like "property" to adapt its historical purposes to the substantially different social context of the regulatory state. Or, as in the latter instance, it may involve generalizing froin existing but unrecognized practices to reconceptualize a concept like "adjudication." Or it inay require other imaginative capacities, ${ }^{319}$ such as the ability to adapt the conceptual apparatus of another discipline. ${ }^{320}$

Still, the socially situated nature of all transformative efforts ineans that they are both constrained by adversity and contingent upon their social and intellectual context. Thus, without an adequate theoretical "map" of the sort described above, transformative theoretical efforts are likely to run headlong into adversity. Predictably, the sedimented nature of a concept like "property" will not support every reformulation. ${ }^{321}$ For example, Rodney Sinolla has described the way in which Reich's reconceptualization ultimately subverted itself: "By urging the Court to treat government benefits as property, the new property inetaphor invited the analysis that would surface in [Board of Regents v.] Roth." 322 According to Sinolla, the Court invoked

the more formal legal reasoning to which lawyers are accustomed in defining the spatial and temporal dimensions or "nature" of an interest. Justice Stewart noted that in defining "liberty" and "property," the Court (and he might have said the legal profession) had "observed cer-

317. Reich, The New Property, 73 Yale L.J. 733 (1964).

318. Chayes, The Role of the Judge in Public Law Litigation, 89 HARv. L. Rev. 1281 (1976). One of the most significant contributions of Cover, Fiss, and Resnik's Procedure is that it devotes over 200 pages to develop and examine Chayes' model of public litigation. R. CovER, O. Fiss \& J. ResNiK, Procedure 219-427 (1988).

319. One example coming from within the practice of normal science is the capacity to use a known but previonsly unrelated experience to reconceptualize an existing practice. See Winter, Bull Durham, supra note 12, at $674-76,686$ (discussing Schön, supra note 290). Another is the ability to understand and adapt another culture's construction of the world to reformulate a paradigm and resolve an anomaly. A. MACINTYRE, supra note 41, at 394-95, discussed in Winter, Bull Durham, supra note 12 , at $671-72$.

320. Law and economics might be an example; although from a hiberal-to-left perspective, one would perlaps see it as an example of counter-revolutionary advent.

321. See Sinolla, The Reemergence of the Right-Privilege Distinction in Constitutional Law: The Price of Protesting Too Much, 35 STAN. L. REV. 69, 81 (1982) ("The term 'property,' after all, carries with it the baggage of hundreds of years of Anglo-American legal tradition.").

322. Id. at 79 (discussing Board of Regents v. Roth, 408 U.S. 564 (1972)). "Of course it was never the intention of Cliarles Reich that his writing be turned against recipients of largess, but, ironically, the development of the entitlement theory is directly traceable to the new property analogy." Id. 
tain boundaries." . . "Property" is a concept connoting circumspection $\ldots .^{323}$

Not surprisingly, then, "[t]he ultimate fate of the new property concept serves as a valuable lesson in the perils of thinking by analogy."324 One must first get clear one's lines of advent.

Transformative theoretical efforts are contingent because they depend upon the existence of significant anomalies within the prevailing matrix. This is true in two senses. First, the effort to develop a new paradigm will usually be generated by the pressure to resolve major anomalies. Second, the potency of any proposed new paradigm will be directly proportionate to the perceived severity of the anomalies. The more destabilizing the anomalies, the inore likely it is that a truly revolutionary paradigm will be accepted. In short, the success of this form of theoretical endeavor is a function of the degree of crisis.

There is also a role for what Michelman identifies as "imterpretation, or internal development, or recollective imagimation."325 But it, too, is a function of the degree of crisis. In the absence of anomaly and crisis, interpretation is nothing so much as the practice of normal science. Interpretation can nevertheless contribute to transformative efforts in threc distinct ways. First, interpretation can extend a normal science to the point at which it begins to break down as a tool for puzzle-solving. Second, imterpretation can deepen an ongoing crisis by amplifying its anomalies. The indeterminacy critique is an example; it has power right now because it undermines the already destabilized inatrix of the law by demonstrating its mability to live up to objectivist expectations. ${ }^{326}$

Third, interpretation can play an important role during times of crisis by seeking to deflect, dampen, or shape the impact of adverse decisions not fully secured by a prevailing matrix.

Whatever the Court says about civil rights, capital punishment, or abortion, the meaning of its constitutional interpretation is as much a matter of our understanding, our interpretive commitments, as it is a matter of the understanding of the Justices. We are part of the context, the larger frame, im which legal interpretation has meaning and resonance. This is

323. Id. at 81 (quoting Roth, 408 U.S. at 572) (emphasis added). For a particularly thoughtful discussion of the role of the boundary metaphor in structuring both our conceptions of property and "self," see Nedelsky, Law, Boundaries, and the Bounded Self, 30 RePRESENTATIons 162 (Spring 1990).

324. Smolla, supra note 321 , at 81 . In light of the above discussion, however, one might disagree with Smolla on just what that lesson is.

325. Michelman, supra note 173, at 258 (citations omitted).

326. Examples of this kind of argument include Kelman, Interpretive Construction in the Substantive Criminal Law, 33 STAN. L. REv. 591 (1981); Simger, The Player and the Cards: Nihilism and Legal Theory, 94 YALE L.J. 1 (1984); Tushnet, Following the Rules, supra note 10. For an explanation of the function of philosophical argument during times of crisis, see T. KUHN, supra note 15 , at 88 . 
the insight that follows when we understand that objectivism is a inyth. ${ }^{327}$

Still, in the end, the effective practice of constitutional pohtics cannot rely on purely interpretive efforts. For the ultimate persuasiveness of these interpretations will depend on their ability to take root in the actual experiences and institutions of the culture. ${ }^{328}$ And this requires social action. "We take our fate in our hands, we become responsible for our history through reflection, but equally by a decision on which we stake our life, and in both cases what is involved is a violent act which is validated by being performed."329

\section{$\mathrm{V}$}

\section{The Situated-Subject's Guide to the Constitution}

In this final part, I explore soine of the imphications for constitutional law of the insight about situatedness. These explorations are deliberately tentative and nondeterminate because I take seriously iny own arguments about situatedness and the limits it imposes on theory and on normative dialogue. Thus, I do not propose to come up with a radical new "theory" of the Constitution that would transform our current (conservative) practices. Nor do I attempt to convince you by adducing reasons to show that my vision of the situated-subject's Constitution is supported by a better normative argument. Rather, I attempt to engage you in a colloquy that draws in two different ways upon your own situatedness. First, I try to persuade you that an understanding of the Constitution as a fully situated phenomenon in all its dimensions is "correct" because it inakes the most sense in terms of what you already know to be true of your own experience. ${ }^{330}$ Second, I try to show you that the significance of the insight about situatedness is already part of the constitutional canon (how could it not be?). I close with an invitation to

327. Winter, Transcendental Nonsense, supra note 12, at 1229 (emphasis in original) (footnote omitted) (discussing Cover, supra note 178, at 5-7).

328. Cf. Cover, supra note 178 , at 44 ("[A] legal interpretation cannot be valid if no one is prepared to live by it.").

329. M. Merleau-Ponty, Phenomenology, supra note 18, at xx. One must admire Cover's wisdoin as well as his honesty when le acknowledges the nature of his constitntional commitments:

I ... celebrate the achievernents of federal courts in destroying apartheid in America. ... I

favor federal courts taking a lead in reforming institntions when the other officials fail. ...

I support those efforts because I beheve thein right and justified, because I am sufficiently committed to them to join with others in imposing our will on those who disagree. At times the federal courts have been our allies in those commitments. There is every reason to believe that such a convergence of interests was temporary and aceidental; that it is already changing and will soon be a romantic unemory of the sublime sixties.

R. COVER, O. FISS \& J. RESNIK, supra note 318 , at 730 (previously impublished note found posthumously).

330. To the extent that this is what Miclelman has in mind when he advocates a dialogic politics, there is less difference between us than might have been suggested at supra Part IV(B). 
explore the potential this creates for the advent of new constitutional meanings.

What we will find, I hope, is that an enhanced notion of constitutional politics entails a reciprocally enhanced conception of constitutional law. To the situated-subject, both the phenomenon of law and the character of the Constitution take on a different, somewhat richer cast. Where mainstream efforts treat constitutional law as if it were (or, rather, should be) the product of a consistent theory, I suggest that it must be seen as the dynamic product of the relentlessly jurisgenerative processes of social and cultural construction. In this view, the Constitution necessarily slips the bonds of mainstream theory as the advent of constitutional meanings play out in an unceasing process of situated jurisgenesis. In contrast to Bruce Ackerman's account of amendment outside the strictures of article V, which he calls "dualist democracy," examples of this third, socially situated mode of constitutional lawmaking. I call this "trimorphic constitutionalism" because it recognizes three, structurally distinct forms (from the Greek tri morphos) of constitutional lawmaking. I argue that this third, "trimorphic" form of constitutional jurisgenesis is both descriptively and democratically superior.

In the final section, I will invite you to consider already sedimented aspects of the tradition from a different angle. My immediate goal is to induce in you a constitutional gestalt switch-that is, to prompt you to see constitutional law from a perspective that would suggest lines of advent different froin our current, conservative trajectory. The more long-range purpose of this endeavor is to lay the groundwork for a new constitutional paradigm. I call this endeavor "reconstitutive constitutionalisin" because it seeks a more meaningful, legal recognition of our inexorable interdependence. ${ }^{332} \mathrm{I}$ will not atteinpt to provide a fully formed picture of what that reconstituted paradigm might look like. For, whatever it might be, it camiot be the product of a simgle mind. On the contrary, it must be inade real in shared social experience.

Before I can make my affirmative argument, however, there are two potential objections that must be considered. Each in its own way builds upon the insights explored in this paper: thus, $I$ have called them the "incommensurability objection" and the "historicist objection," respectively. Although each of these objections is sensitive to-indeed, premised on-an appreciation of the situatedness of the legal enterprise, each founders because of its residual dependence on the subject/object dichotouny.

331. Ackerman, Constitutional Politics, supra note 5, at 461-62; Ackerman, Storrs Lectures, supra note 5, at 1038-43.

332. See Winter, The Metaphor of Standing, supra note 12, at 1478-516. 


\section{A. Avoiding the Subject/Object Dichotomy}

\section{The Incommensurability Objection}

The incommensurability objection finds it difficult even to conceptualize where one might locate situatedness in our Constitution, conceived as it was by a generation steeped in Enlightenment premises of rationalisin and individualisin. ${ }^{333}$ If, as I have argued, the law should be understood as a stabilized inatrix which determines the arguments and perspectives that will be understood as relevant, then the entire history of the Constitution is incommensurate with-and therefore should be secured from-fancy Continental ideas like "situatedness."334 The idea of a reconstitutive constitutionalism sounds like nothing so much as the project of a philosophical Schneiderman-that is, someone who "can be attached to the Constitution no inatter how extensive the changes are that he desires, so long as he seeks to achieve his ends within the framework of Article V."

The problem with this objection, however, is that it reinscribes the subject/object dichotomy, presupposing both an objectification and a certain essentialisin. This objection treats the concept of a stabilized matrix as soinehow separate froin the actual community that embodies it. ${ }^{336}$ It views the Constitution as a "thing" into which the framers deposited their ideas, a text into which they inscribed their individualist assumptions. But the subject and its objects cannot be separated in this fashion: A stabilized matrix is nothing more than the beliefs, assumptions, and inental processes of actual people; it is not a property of the texts that they draft and interpret. It follows that no antecedent inatrix can determime subsequent interpretations by other people at a later time. ${ }^{337}$ Because the Constitution is a text to be interpreted, it necessarily changes as new assumptions inediate the reading of its text. ${ }^{338}$

333. I choose this phrasing to capture the shared premises of both the Lockean hiberals and the republicans, as the discussion of Michelman deunonstrates.

334. See Ackerman, Constitutional Politics, supra note 5, at 453-55 (complaining that America remains "an intellectual colony, borrowing European categories to decode the meaning of its national identity").

335. Schneiderman v. United States, 320 U.S. 118, 140 (1943) (declining to consider "this extreme position"). For a thoughtful discussion of Schneiderman, see S. LEVINSON, Constitutional FaITH 122-54 (1988).

336. Cf. Kuhn, Second Thoughts on Paradigms, in The Structure of ScIENTIFIC TheorIes 459,460 (F. Suppe ed. 1972) ("A paradigm is what the members of a scientific community, and they alone, share. Conversely, it is their possession of a common paradigm that constitutes a scientific community of a group of otherwise disparate men.").

337. This is not to say that, within a given culture, a text can be interpreted in just any way. Rather, the processes of sedimentation and the phenomena of adversity and advent will affect subsequent readimgs. There will be variance and nondeterminacy in interpretation, but not radical indeterminacy. See, e.g., Wimter, The Cognitive Dimension, supra note 12, at 2245-55.

338. For literary and cultural examples, see $i d$. at 2252-55. 
A single example should suffice to deinonstrate both that the Constitution constantly changes and that this process of change can sustain the advent of a new understanding that recognizes situatedness in our Constitution. Consider the fourth amendment's protection "against unreasonable searches and seizures." 339 Its scope has varied widely, dependimg on the mediating concept used to characterize the protected interest. For much of our history, this constitutional provision was understood to protect a sphere of autonomy marked out by the common law protections of property and persons. ${ }^{340}$ In this form, the fourth amendment was both broader and narrower than its modern counterpart-prohibiting the search for and seizure of "mere evidence,"341 but permitting wiretapping. ${ }^{342}$ When reconceptualized in terms of "privacy," however, exactly the opposite became the case. ${ }^{343}$ Reformulated agam as "a legitimate expectation of privacy"344 — well, the story is wellknown.

Arguably, the framers' underlying individualist assumptions remain constant throughout these doctrimal permutations. In this sense, the individualist assumption is deeply sedimented in the legal mind. ${ }^{345}$ The crncial point, however, is that the meaning and shape of this individualism have changed continually and dramatically as the mediating conceptions have varied. ${ }^{346}$ And this fact of constant change in our constitutional conception of the individual is sufficient to illustrate my argument for the situated-subject's Constitution. For the purpose of this exercise is not the effacement of the individual. Quite the contrary, my critique has been that-without consideration of context and situationthe individualist promise of constitutional formahism can ouly be a cruel

339. U.S. CONST. amend. IV.

340. See, e.g., Gouled v. United States, 255 U.S. 298 (1921); Boyd v. United States, 116 U.S. 616,630 (1886).

341. Gouled, 255 U.S. 298 passim.

342. Olmstead v. United States, 277 U.S. 438 (1928).

343. See Warden v. Hayden, 387 U.S. 294 (1967); Katz v. United States, 389 U.S. 347 (1967). But see Amsterdam, Perspectives on the Fourth Amendment, 58 MinN. L. Rev. 349, 385 (1974) ("The effect of Katz is to expand rather than generally to reconstruct the boundaries of fourth amendment protection.").

344. See, e.g., Hudson v. Palmer, 468 U.S. 517 (1984) (prisoner has no legitimate expectation of privacy in prison cell); Smith v. Maryland, 442 U.S. 735, 740 (1979) (no legitimate expectation of privacy in the numbers dialed on one's phone); United States v. Miller, 425 U.S. 435 (1976) (no legitimate expectation of privacy in records of deposit slips and canceled checks held by bank).

345. For such an argument, see Winter, The Metaphor of Standing, supra note 12, at 1481-91; Fischl, supra note 262, at 861-63.

346. See White, Judicial Criticism, 20 GA. L. REv. 835, 849 (1986) ("The Court's view on these questions does much to define what it neans to be a citizen in our country, for these cases tell us what actions by officials count as intrusions ....."); see also Note, The Life and Times of Boyd v. United States (1886-1976), 76 MrCH. L. REv. 184, 194 (1977) ("To the extent that the decisions following Boyd and Gouled reduced the obstacles to governmental seizure of an individual's property, they also narrowed his effective zone of privacy."). 
hoax. ${ }^{347}$ Instead the thrust of my argument is toward the reconceptualization of the individual in a manner more true to its actual situatedness. ${ }^{348}$

\section{The Historicist Objection}

The historicist objection recognizes that there is no critical charge to the insight that we are socially constructed and applies the point with a vengeance. The objection starts from the premise that "a society is not a collection of pure, free, and equal consciousnesses but is first of all a system of institutions to which consciousnesses owe whatever effective reason and hiberty they might have."349 If everything is socially and historically contingent in this way, then it is all the more critical that we preserve the inherited values and social structure because they make us who we are. ${ }^{350}$ In this view, the idea of the situated-subjeet's Constitution could only yield a conservative Burkean organicism.

What is asserted by an organic or evolutionary theory is that the purposes of legal rules cannot be fully known. Put more cogently, . . . legal rules ... should presumably contribute to the maintenance of an effective social order, we cannot expect to know precisely how they do so and what the long-term effects of changes or revisions might be. Our constitutional stance should therefore be preservative and incremental, building carefully, by analogy, upon traditional modes of operation. So viewed, the justification "we have always done it that way" is not so much a retreat from reasoned and purposive decision making as a profound acknowledgement of the limits of instrumental rationality. ${ }^{351}$

There are three related problems with the historicist objection. First, it presupposes that, although our values are contingent, our reality is relatively stable. It necessarily assumes that the fundamental nature of

347. See supra text accompanying notes 219-25.

348. As I have argued elsewhere, this is not the elimination of freedom, but the very condition of its possibility. Winter, Bull Durham, supra note 12, at 655-56, 684-85. As Merleau-Ponty puts it, the situated-subject is

a being with a natural and social situation but one who is also open, active, and able to establish his autonomy on the very ground of his dependence. ... [T] he bond which attaches man to the world is at the same time his way to freedom; ... man, im contact with nature, projects the instruments of his hiberation around himself not by destroying necessity but, on the contrary, by utilizing it ....

M. MERLEAU-PONTY, SENSE AND NON-SENSE, supra note 21, at 130.

349. Id. at 103 .

350. Kronman, Precedent and Tradition, 99 YALE L.J. 1029, 1066 (1990) ("We must respect the past because the world of culture that we inherit from it makes us who we are."). Kronman, however, goes further and argues that we have a duty to preserve this otherwise perishable world of culture, including law. Id. at 1052-54, $1064-68$.

351. Mashaw, The Supreme Court's Due Process Calculus for Administrative Adjudication in Mathews v. Eldridge: Three Factors in Search of a Theory of Value, 44 U. CHI. L. REv. 28, 55 (1976) (emphasis in original); see also West, Constitutionalism, supra note 291, at 654-55, 675-76 (constitutional conservatives treat the past as the ouly rehiable source of wisdom and values). 
the problems facing a society do not change drastically over time: The historicist prescription-stick to the tried-and-true as augmented by mcremental adjustment-only makes sense if there is a relative stability to the physical and social realities with which a society grapples. ${ }^{352}$ But as soon as the historicist objection acknowledges contingency, it must also acknowledge the contingency of history itself. ${ }^{353}$ There can be no guarantee that changes in historical circumstances are gradual rather than drastic and, therefore, that appropriate legal change shonld be incremental rather than radical.

The second problem with the historicist objection is that it depends upon a strong distimction between the substance of a rule and its animating spirit. On one hand, it necessarily assumes that the substance of the received rules is relatively clear and determinate: only then could we preserve and follow those rules (as augmented by incremental adjustment, of course). At the same time, however, it is utterly skeptical of our ability to know either the purposes of those rules or the means by which they operate. Thus, it presupposes that we can know the meaning without the reason, that the what somehow remams stable even as the why and the how recede into oblivion. ${ }^{354}$

The third problem with the historicist objection is that it puts the past and present in conflict. While it esteems society's values and seeks to nurture them for the fragile, precious creations they are, ${ }^{355}$ it is utterly skeptical of the capacity of contemporary humans to create equally valuable constructions. Where our forebears were wise and ruled by reason, we are decadent and likely to be ruled by passion. ${ }^{356}$ Indeed, the historicist objection necessarily assumes that-even though, by hypothesis, we are constructed along their lines-we are somehow unable rationally to respond to changing circumstances as well as they were. ${ }^{357}$

352. See Ackerman, Constitutional Politics, supra note 5, at 476 ("However well Burkean incrementalisın inay fit the British experience, it falsifies the distinctive character of the Ameriean."); Mashaw, supra note 351, at 54 ("Since social and economic forces are dynamic, the processes and structures that proved functional in one period will not necessarily serve effectively in the next.").

353. Kronman seems to acknowledge contingency when he recognizes that "the effort to reproduce, unaltered, an existing inode of hnman life almost always results in its inodification, despite the intentions of those involved." Kronman, supra note 350, at 1052. Nevertheless, he does not seem to aecount for this factor in his subsequent arguinent.

354. As I have deinonstrated elsewhere, however, even simple words likc "vehicle" and "park" come with their purposes and contexts already built into our very understandings of the terms. Winter, Transcendental Nonsense, supra note 12, at 1178-80.

355. Cf. Rorty, Thugs and Theorists: A Reply to Bernstein, 15 Pol. Theory 564, 579 n.28 (1987) ("[T]he moral intuitions of the average middle-class member of a modem Western society are contingent, fragile, precious creations, not the expression of soinething universally huinan.").

356. In this view, "[t] he political man is he who has recognized the price of existing things and defends them against private fantasy." M. MERLEAU-PONTY, SENSE AND NON-SENSE, supra note 21 , at 103.

357. See Michelman, Conceptions of Democracy in American Constitutional Angument: The Case of Pornography Regulation, 56 TENN. L. REV. 291, 316-18 (1989) (conventional approach to judicial 
A common thread runs through each of these distinctions: some things are dependable, others not; some things are solid, otliers epliemeral. Mostly, of course, reality, the rules, and the past are (relatively) solid and reliable. On the other hand, values are contingent; the spirit or purpose of the inherited rules are unknowable; and contemporary people are unreliable. If any of this sounds vaguely familiar, it is because it replicates the subject/object dicliotomy. The object-that is, reality, the rule, the past-is good. The subject-that is, current values, the intention behind the rules, present-day liumans-is subjective and bad.

Because the historicist objection depends on the subject/object dicliotomy, it cannot witlistand the reconceptualization of subject-object relations. If the situated-subject is both constituted and constituting, then it is snnultaneously dependent on its past and every bit as imvolved in the world as its forebears. Whatever the inherited social constructions that constitute it, the subject inevitably encounters new situations that require imaginative new interactions. Thus, the historicist objection fails both in its conception of the past and in its false limitation of tlie future. By the same token, it fails because the contingency of the future can never be obviated. "Under tlie pretext of objectivity it freezes the future and eliminates change and the will of men from history."358 At the same tinne, the historicist objection also fails because the past of values and rules is never separate and behind and, thus, not something that needs to be preserved. "[T]liere is no . . . completely real and accomplished history[] because the historical reality of which we can speak has meaning only for a [person] who is situated in it and wants to go beyond it and therefore has meaning only within a framework of possibilities."359 The past is, rather, the sedimented knowledge with which one interacts with the problems of the present. It is this sedimentation that is preservative of the past. ${ }^{360}$ At the same time, this sedimentation is always an interaction with a mcessantly dynamic present.

\section{B. Relentless Jurisgenesis}

\section{Jurisgenesis in Action}

Like the late Robert Cover, Merleau-Ponty understood the deeply luman capacity for jurisgenesis: the relentlessness witlı whiclı liumans

enforcement of the Constitution imagines "the Constitution's own founding moment as on the yonder side, before the Fall, a part of Edenic time, and only posterity's politics (only all the rest of political timel) as after the Fall").

358. M. MERLEAU-Ponty, SENSE AND Non-SENSE, supra note 21, at 168.

359. M. Merleau-Ponty, Dialectic, supra note 1, at 134 n.70; see also M. MerleauPonty, Phenomenology, supra note 18, at 173 ("[T] here is history only for a subject who lives through it, and a subject only in so far as he is historically situated.").

360. Cf. M. MerLeau-PonTY, Signs, supra note 25, at 96 ("Truth is another name for sedimentation, which is itself the presence of all presents in our own."). 
construct the normative world that they inhabit. "All several men need do is live together and be associated with the same task for some rudimentary rules and a beginning of law to emerge from their hfe im common."361 This enhanced conception recognizes law as one of the ways humans cope by stabilizing contexts in which they can interact and commumicate with each other. ${ }^{362}$ Viewed in this way, we cannot even begin to understand the phenomenon of law as long as we consider only those products of "the strictures of provenance that characterize what we call formal lawmaking."363 Rather, law is the unmistakable product of human interactions as they are institutionalized first in social practice and then as cultural and legal norms.

Karl Llewellyn's 1934 article on constitutional law provides a wonderfully wry example. Llewellyn argued that the Constitution conld ouly be understood as an ongoing institution deeply rooted in our mores and cognitive makeup. ${ }^{364}$ To illustrate his point, Llewellyn cited the thenunbroken practice initiated by George Washington in which the President serves only two terms. He was careful not to claim too much. Nevertheless, he did assert that, as an ingramed governmental practice, the two-term rule was every bit as much a part of the Constitution as the presidential veto.

Do I mean that the Supreme Court would, on demand, declare the third election of a president to be void? Of course not. I mean that institutions which sit so firmly that the Supreme Court never gets a chance to pass on variations from them attain the zemith of fundamental law's perfection. $^{365}$

The irony, of course, is that six years later Roosevelt would be elected to a third term. Even so, there is a kind of cultural "truth" value to sedimented social practices that is not to be denied. In 1951, the Constitution was amended to provide that: "No person shall be elected to the office of the President more than twice . . ."366

Not all sucli practices end up codified in the text of the Constitution itself. Nevertheless, there is a powerful trajectory that runs from social practice through institutionalization as cultural norm to constitutional command. Consider the double irony of the right to travel. The right is

361. M. Merleau-Ponty, SenSe AND NoN-Sense, supra note 21, at 118. Compare id. with Cover, supra note 177, at 1602 n.2 ("[T] he creation of legal meaning is an essentially cultural activity which takes place (or best takes place) among smallish groups.") (emphasis in original).

362. See supra text accompanying notes 21-23 \& 31-36.

363. Cover, supra note 178 , at 18 .

364. Llewellyn, supra note 65 , at 18 ("[A] firmly established constitution . . . mvolves ways of belavior deeply set and settled in the make-up of these people-and it involves not patterns of doing (or of inhibition) merely, but also accompanying patterns of thinking and of emotion ....").

365. Id. at 14 (footnote omitted).

366. U.S. CoNST. amend. XXII, §1. 
considered "fundamental,"367 "firmly established and repeatedly recognized," 368 despite the fact that it appears nowhere in the Constitution and despite the inability of the Court even to agree on which provision in the Constitution provides a textual anchor for the right. ${ }^{369}$ And, yet, it makes perfect sense. In their amicus brief in the Webster case, Norman Redhch, Frank Michelman, Stephen Neuwirth, and the late Denise Carty-Bennia, put it aptly:

[U]nenumerated rights traditionally have reflected powerful historical forces that inevitably influence constitutional interpretation. The right to travel, nowhere specified in the constitutional text, becoines understandable when one considers the ambulatory nature of early American society, in which settled communities were rare, and immigration and the conquering of the frontier were urgent national concerns. ${ }^{370}$

Indeed, what could be nore fundamentally American than the right to travel? (Renieniber the ad? "It's not just your car; it's your freedoin.") The energence and institutionalization of the right to travel as an unspecified, textually ungrounded constitutional right is a powerful exeniplar of the constant process of constitutional jurisgenesis.

\section{Trimorphic Constitutionalism}

\section{a. Ackerman's Dualist Democracy}

In the received wisdom, judicial review is seen as countermajoritarian because it invalidates the products of the majoritarian political process. Bruce Ackerman refers to this view as "monistic democracy" because, regardless of differences over such issues as when judicial review is nevertheless appropriate, the underlying assumption is that the essence of democracy lies in the ordinary electoral process by which the populace chooses the legislature and executive. ${ }^{371}$ In contrast, Ackerman argues that our historical tradition supports a "dualist deniocracy" that distinguishes between normal politics and a "higher track" of constitutional politics. ${ }^{372}$

[T] The Constitution establishes a two-track law-making system. If our elected pohiticians hope ouly to win normal democratic legitimacy for an imitiative, they are directed down the normal lawinaking path and told to

367. United States v. Guest, 383 U.S. 745, 757 (1966).

368. Id.

369. Shapiro v. Thompsou, 394 U.S. 618, 630 (1969) ("We have uo occasiou to ascribe the source of this right to travel interstate to a particular constitutional provisiou.").

370. Brief for a Group of American Law Professors As Amicus Curiae in Support of Appellees at 15, Webster v. Reproductive Health Servs., 109 S. Ct. 3040 (1989) (No. 88-605). Of course, the phenomenou has even deeper roots in the commou law. See $1 \mathrm{~W}$. BLACKstone, CoMmENTARIES *130 (1765) ("[P]ersoual liberty consists in the power of loco-motion, of changing situation, or of removing one's person to whatsoever place one's own inclination may direct ....").

371. Ackerman, Constitutional Politics, supra note 5, at 462-65.

372. Id. at 461-62; Ackerman, Storrs Lectures, supra note 5, at 1039-43. 
gain the assent of the House, Senate, and President in the normal ways. If, however, they hope for higher lawinaking authority, they are directed down a specially onerous lawmaking path .... ${ }^{373}$

To make higher law, which imcludes amendment of the Constitution outside article $\mathrm{V}$, it is necessary first to traverse "the specially onerous obstacle course provided by a dualist constitution for this purpose."374 Along this route, a movement must

first, convince an extraordinary number of its fellow citizens to take its proposed initiative with a seriousness that they do not normally accord to politics; second, allow opponents a fair opportumity to organize their own forces; third, convince a majority of Americans to support transformative initiatives as their merits are discussed, tinue and again, in the deliberative fora provided by the dualist constitutional order for this purpose. ${ }^{375}$

Ackerman identifies Reconstruction and the New Deal as two pivotal, but not exclusive, examples of this method of higher lawmaking. ${ }^{376}$

Ackerman's notion of dualist democracy yields a distinctive defense of and limitation on judicial review. In his scheme, the judiciary's duty is to preserve the fruits of constitutional politics from the vicissitudes of normal pohtics.

[T]he dualist sees the discharge of the preservationist function by the courts as an absolutely essential part of a well-ordered democratic regime. Rather than threatening democracy by frustrating the statutory demands of the pohtical elite in Washington, D.C., the courts serve democracy by protectimg the hard-won judgments of a mobilized citizenry against fundainental change by political elites who have failed to establisli the requisite kind of nobilized support from the citizenry at large. ${ }^{377}$

In a closing metaplior, Ackerman compares the American republic to a train steaming througl history. While the passengers periodically clioose a new engineer or debate a new course, the courts, lie says, must always "remain in the caboose, looking backward."378

Others will no doubt find fault witlı the dualist thesis because it is

373. Ackerman, Constitutional Politics, supra note 5, at 464 (emphasis in original).

374. Id. at 462 .

375. Id. at 461 .

376. Ackerman notes and discusses the differences between Reconstruction and the New Deal. During the former, Congress was the primary locus of transformative efforts and the recalcitrant branch was the Executive. In the latter, it was the executive that took the initiative and the Court that resisted. Moreover, although the Reconstruction Era partially nationalized the process, the states were still nominally involved in ratification. In the New Deal, however, the process was nationalized in its entirety. Id. at 511-15.

What is distnictive, however, is that in each case the trajectory of this second of the dualist paths aecords with the following schema: "Constitutional Impasse $\rightarrow$ Triggering Election $\rightarrow$ Challenge to Institutional Legitimacy $\rightarrow$ Switch In Time." Id. at 509.

377. Id. at 465 (enuphasis in original).

378. Id. at 546 (emphasis oinitted). 
incommensurate with the text of the Constitution and the received understanding. ${ }^{379}$ For my part, I think that Ackerman's analysis is useful and important as an account of certain constitutional paradigm shifts. Compared to the parsimony of the monists, Ackerman's constitutional populism is refreshingly generous. ${ }^{380}$ On the other hand, even Ackerman's enlarged sense of constitutional jurisgenesis is both undnly restrictive and insufficiently democratic. First, a dualist understanding of democratic constitutionalism is at least one track too few; only a threetiered, trimorphic constitutionalism can begin to describe the actual practice of American constitutional law. Second, regardless of its descriptive accuracy, the dualist account leaves something to be desired on its own normative terms. In contrast, the third track that I identifya track of ordinary, everyday jurisgenesis-looks surprisingly more deinocratic.

\section{b. Three-Track Jurisgenesis}

Ackerman's dualist theory is unable to accommodate the realities of constitutional jurisgenesis, as the emergence of the right to travel illustrates. Imagine Ackerman at the starting gate of the dualist track: "O.K., People. Here's the drill. You see, there are these four hurdles you will have to clear before you can change the Constitution outside article V. Now, ...." By the time he has finished describing the first hurdle, the Constitution has already changed-and without our noticing. The event, moreover, cannot be captured and domesticated by the rubric of "interpretation," at least not as that term is conventionally understood within constitutional law and practice. Consider again the right to travel, which isn't derived from any particular constitutional clause.

The most interesting constitutional changes are not those that are self-consciously mediated by imterpretive strategies, but rather those that happen without conscious awareness of "change." Here, as elsewhere, Llewellyn's eye was keen:

[A] rule is made up of a series of words, a nexus of linguistic symbols.... [T]o an indeterminate degree, every symbol ... has what may be called latent content: it has an unambiguous and predictable (along with an ambiguous and not fully predictable) capacity for expanding. Once something new and different appears, something not thought of before, it can be felt to fit within existing categories. In this sense, every category in fact has an immanent expansive capacity. This expansive capacity is clearly predictable to some extent, but only to some extent. [Assume a] hypothetical case [in which] every lawyer would expand the rule the

379. See, e.g., Tushnet, supra note 3, at 539 n.1.

380. See also Amar, Philadelphia Revisited: Amending the Constitution Outside Article V, $55 \mathrm{U}$. CHI. L. Rev. 1043, 1044 (1988) (discussing the "right of majority of voters to amend the Constitution ... . in ways not expressly provided for by Article V'). 
same way. But when he does so, he does so instantaneously; he does not see the expansion. . . . Nevertheless he has, even if unwittingly, expanded the category. ${ }^{381}$

This expansive capacity, moreover, is dependent on the development of social norms. "All words (that is, linguistic symbols) and all rules composed of words continuously change ineaning as new conditions emerge."382 Thus, the inost important concern for the legal decisionmaker is

whether [she] can make the direction and degree of semantic change in a legal rule (or a verbal symbol used by the rule) keep up with the corresponding change in the real-life situation. If the change sanctioned by the judge keeps up more or less, but not qinite, one then speaks of the law's mild conservatism. If the change on the judge's part is noticeably not keeping up, one then speaks of a crisis in decision inaking. And, finally, if the change on the judge's part is keeping up perfeetly, neither judge nor layman realizes that any change has occurred . . . ${ }^{383}$

What was salient about the pre-1937 New Deal period was that judicial change was demonstrably not keeping up. Almost everybody knew it, and the consequences could not be ignored-which is another way of saying that the anomalies were escalating out of control and a fullfledged crisis was under way.

These insights have intrigning implications for the conventional conceptualization of the countermajoritarian difficulty. They suggest that, in times of crisis like the New Deal, it is the absence of judicial "nmovation" that is widely perceived to be undemocratic. In times of relative stability, on the other hand, cases like those involving the right to travel are decided in the ordinary course of constitutional jurisgenesis. Indeed, there may be hittle awareness of the change and even less concern with the deinocratic dimensions of the process. But it is nevertheless democratic-in a trimorphic sort of way, of course.

\section{c. Coming Up Short I: Reconstruction and the Problem of Method}

Ackerman's dualist theory betrays its shortcomings as soon as we apply its own normative deinocratic commitments to the actual historical record. Consider first Ackerman's careful account of the events that led to the adoption of the fourteenth amendment. ${ }^{384}$ At the encouragement

381. K. Llewellyn, The Case Law System in America 74-75 (P. Gewirtz ed, M. Ansaldi trans. 1989) (emphasis im original) (footnote omitted). In the omitted footnote, Llewellyn explained what he meant by "an immanent expansive capacity": "Sociologically immanent, that is, if one presupposes determinate historical circumstances, existing legal practice, and lawyers trained in a particular tradition and particular doctrinal materials ...." Id. at $74 \mathrm{n} .1$ (emphasis in original).

382. Id. at 83 .

383. Id.

384. Ackerman, Constitutional Politics, supra note 5, at 500-10. 
of President Andrew Johnson, the all-white governments of the Southern states rejected the Radical Republicans' proposed amendment. ${ }^{385}$ Both sides took the issue to the electorate in the 1866 congressional elections, which resulted in "a decisive electoral victory for the party of constitutional reform." ${ }^{386}$ Armed with this mandate, the Republicans responded with the Reconstrnction Acts of 1867 and 1868. They replaced the existing Southern governments with military rule and required the army to register Southern blacks to vote. Even so, the reconstructed Southern governments were only allowed to rejoin the Uinion on the condition that they ratify the fourteenth amendment. ${ }^{387}$

Johnson used his power as Commander-in-Chief to slow the process of ratification so that he could take the issue back to the electorate in the 1868 presidential election. Congress responded by impeaching the President, subjecting him to trial in the Senate. ${ }^{388}$ Between March and May of 1868, Johnson bowed to the requests of Repubhican senators and called off his efforts to obstruct Reconstruction and ratification. Seven Republican Senators voted to acquit; Johnson escaped conviction by one vote. The ratification of the fourteenth amendinent then proceeded under the strictures of Reconstruction. ${ }^{389}$ It became part of the Constitution in Jnly, 1868.

As Ackerman suggests, "we shonld ask how well [this] systein serves the basic principles of dualist democracy." 390 I suspect that many people will be troubled about the democratic legitimacy of this process as it has been described. The essence of the dualist track is that the "President, Congress, Court, and voters interact with one another over time to test the constitutional credibility of the movement's mandate to speak for the People on behalf of its transformative initiative."391 But one inust question whether in 1868 the Republican Congress really allowed opponents "a fair opportunity to organize their own forces."392

385. The proposed amendment was itself the product of a rump. Congress dominated by the Radical Republicans after they had refused, in December 1865, to seat any of the Southern representatives. Id. at 500-03.

386. Id. at 505.

387. See id. at 504-07.

388. Id. As Ackerman notes, Congress exercised control over the Court as well. In 1863, the Snpreme Court had grown to ten Justices. P. Bator, P. Mishkin, D. Meltzer \& D. Shapiro, Hart aNd Wechsler's The Federal Courts aNd the Federal System 36 (3d ed. 1988) [hereinafter HART AND WEChSLER's FEDERAL CoURTS]. In 1866, however, Congress reduced the size of the Snpreme Court to seven in order to prevent President Johnson from filling existing vacancies. Ackerman, Constitutional Politics, supra note 5, at 513 n.122. In 1869, after the constitutional crisis was resolved in Congress' favor, it increased the size of the Court to nine. Id.; see also HART AND WechSLER's Federal Courts, supra, at 36.

389. Ackerman, Constitutional Politics, supra note 5, at 505-07.

390. Id. at 515 .

391. Id. at 490 (einphasis added).

392. Id. at 461. 
For the most part, the tactics of the Radical Republicans sound like nothing more than brute power politics: destroying the existing white governments of the South; threatening to unseat Andrew Johnson; and, in each case, making their opponent's continued pohtical existence contingent upon approval of the fourteenth amendment.

To sustain the dualist's case for the democratic legitimacy for these actions, Ackerman must put extraordinary freight on the election of 1866. Even so, one must question whether a single off-year election quite suffices for "higher" lawmaking. Under the strictures of article V, amendment requires a supermajority both in Congress and among the states. Ackerman's own proposed alternative contemplates at least two transformative elections. ${ }^{393}$ Yet, the Republican Congress' strong-arm tactics in advance of the 1868 presidential election pretermitted the possibility of any further test of their "mandate."

The weakness of the dualist's case for the legitimacy of the Reconstruction amendments is accurately reflected in the swiftness and ease with which the Supreme Court eviscerated the legal legacy of Reconstruction. ${ }^{394}$ In 1873, the Court rejected the idea that the privileges and immunities clause of the fourteenth amendment provided any additional federal rights to be protected against state interference. ${ }^{395}$ The clause has remained moribund ever since. Between 1875 and 1883, the Court repeatedly invoked the state action doctrine to undermine the major work of Reconstrnction. In 1875, the Court restricted the application of the criminal provisions of the 1870 Act. ${ }^{396}$ In 1882, it mvalidated a criminal provision of the 1875 Act. ${ }^{397}$ The next year, in the Civil Rights Cases, the Court held the public accommodations provision of the 1875 Act unconstitutional. ${ }^{398}$ With the Court's approval of Jim Crow laws at the close of the century, ${ }^{399}$ the undoing of Reconstruction was complete. In a very real sense, the fourteenth amendment would remain moribund until Brown.

\section{d. Coming Up Short II: The New Deal and the Problem of Scope}

Ackerman's account of the New Deal, at first glance, fares better as a model of democratic jurisgenesis. The New Deal was consistently rati-

393. Ackerman, Transformative Appointments, 101 HARV. L. REv. 1164, 1182 (1988).

394. Blackmun, Section 1983 and Federal Protection of Individual Rights-Will the Statute

- Remain Alive or Fade Away?, 60 N.Y.U. L. REv. 1, 9 (1985) ("[W]ith a few quick thrusts, the Court cut the heart out of the Civil Rights Acts.").

395. Slaughter-House Cases, 83 U.S. (16 Wall.) 36 (1873).

396. United States v. Cruikshank, 92 U.S. 542 (1875) (conviction for lynching of black citizens reversed for failure to allege violation of a particular federal right).

397. United States v. Harris, 106 U.S. 629 (1882) (invalidating provision prohibiting private conspiracies to deprive persons of the equal protection of the laws).

398. Civil Rights Cases, 109 U.S. 3 (1883); see supra text accompanying notes 296-99.

399. Plessy v. Ferguson, 163 U.S. 537 (1896). 
fied at the polls through three elections, culminating in the 1936 presidential election. And so, it should not be surprising that, in contrast to the Reconstruction, the inajor legacy of the New Deal-the activist welfare state-has reinained intact.

Yet, even here, we inay question whether all higher lawmaking of the New Deal period passes muster as a matter of dualist deinocratic legitimacy. As previously noted, ${ }^{400}$ the 1937 paradigm shift inanifested itself $\mathrm{m}$ areas other than those affectimg the constitutionality of the regulatory state. In a few short years, two pillars of inodern federal courts doctrine-constitutional standing law ${ }^{401}$ and the Erie decision ${ }^{402}$-both made their appearance. In an important sense, these legal developments were coherent with the conceptual underpinnings of the 1937 shift: Both emanated from Justice Brandeis' progressive commitınents, and both were closely related to the Court's repudiation of the Lochner era. ${ }^{403}$ The development of standing law was a largely self-conscious effort to impose procedural restraints on the Court so it could not imterfere with progressive legislation. ${ }^{404}$ Erie freed state common law from the imposed national uniformity of the federal courts. ${ }^{405}$ It reflected Justice Brandeis' strong commitment that the states should have leeway to experiment in social and economic matters. ${ }^{406}$

Nevertheless, these two developments raise important questions about the dualist theory. Standing law and Erie are substantial revisions of article III and the concept of federalism, respectively. As constitutional changes, they rank with any of the exphicit annendinents. Yet, one must wonder whether "their merits [we]re discussed, time and again, in [any] dehberative fora"; 407 it is hard to imagme that they were the subject of popular mobilization and debate $\mathrm{m}$ any election. Indeed, when considered along other dimensions, these two developments were in important ways incongruent with the concerns that dominated the great national debate attending the New Deal. Both in conception and effect, standing law is nothing so inuch as the preservation of the background common

400. See supra note 96; sources cited supra notes $67 \& 107$.

401. Coleman v. Miller, 307 U.S. 433, 460 (1939) (Frankfurter, J., concurring); Ex parte Levitt, 302 U.S. 633 (1937) (per curiam).

402. Erie R.R. v. Tompkins, 304 U.S. 64 (1938).

403. See Tribe, supra note 96 , at 25.

404. Winter, The Metaphor of Standing, supra note 12, at 1455-57.

405. It is also true that Erie can be viewed as "the principal case recognizing the constructed rather than prepohtical character of the common law." Sunstem, supra note 9, at 882.

406. See New State Ice Co. v. Liebmann, 285 U.S. 262, 311 (1932) (Brandeis, J., dissenting) ("It is one of the happy incidents of the federal system that a single courageons State inay, if its citizens choose, serve as a laboratory; and try novel social and economic experiments without risk to the rest of the country.").

407. Ackerman, Constitutional Politics, supra note 5, at 461. 
law regime that the 1937 paradigm shift was supposed to reject. ${ }^{408}$ In shifting power from the national courts to the states, Erie precisely reversed the New Deal's affirmance of a strong national government.

In sum, both of the primary exemplars of dualist constitutional change fall short of the deinocratic inark. For Reconstruction, the problem is a inatter of questionable procedure. For the New Deal, the extent and nature of the substantive changes were not coextensive with the subject matter of the popular dialogue and vote.

\section{e. A Trimorphic Exemplar}

The trimorphic mode of constitutional change, im contrast, is deinocratically superior. In this mode, the relentless processes of social and cultural construction produce new sedimentations that are first institutionalized in social practice and then concretized as constitutional rules. ${ }^{409}$ In its highest form, trimorphic jurisgenesis is marked by a moment of conscious, situated reflection in which the Court probes the developinent of and experience with these social norms before transinuting thein into constitutional commands.

My primary exeinplar is a "liberal" criminal procedure decision of the Burger Court, Tennessee v. Garner. ${ }^{410}$ Before Garner, the common law fleeing-felon rule allowed police to use deadly force to prevent the escape of fleeing felony suspects. The Court upset this rule in Garner. It held that, absent probable cause to beheve the suspect dangerous, the use of deadly force to prevent escape constituted an unreasonable seizure of the person in violation of the fourth amendment. ${ }^{411}$ The Court's ruling invalidated the laws of about twenty-three states, "a seemingly striking example of the countermajoritarian practice of judicial review."

The conservative Burger Court's apparent about-face in Garner, ${ }^{413}$

408. See Winter, The Metaphor of Standing, supra note 12, at 1470-78 (demonstrating the conceptual identity of Simon v. Eastern Kentucky Welfare Rights Organization, 426 U.S. 26 (1976), and Palsgraf v. Long Island Railroad, 248 N.Y. 339, 162 N.E. 99 (1928)); see also Sunstein, supra note 9, at 893-94; Sunstein, Standing and the Privatization of Public Law, 88 COLUM. L. REV. 1432 (1988).

409. Michelman disparages this conception "as a kind of behind-our-backs self-government." Michelman, supra note 96, at 1508 n.53. Though partly right, this characterization does not fully consider the reflective coinponent of the process as described below.

410. 471 U.S. 1 (1985).

411. Id. at 11.

412. Winter, Tennessee v. Garner and the Democratic Practice of Judicial Review, 14 N.Y.U. Rev. L. \& Soc. Change 679, 682 (1986). It is not possible to assess precisely how many states were affected because, in several states, the law was quite unclear. See id. at 680-82 nn.11-16.

413. Previous holdings of the Burger Court had embraced a narrow reading of the fourth amendinent's application to searches. See The Supreme Court-Leading Cases, 99 HARV. L. REv. 120,248 (1985). 
its willingness to break with the consensus of the lower courts, ${ }^{414}$ and its invalidation of so many state statutes, nicely emphasize the trimorphic, socially contingent nature of constitutional decisionmaking. By the time Garner came to the Court in 1984, the deadly force policies of most of the police departinents in the country were substantially more restrictive than the common law rule. ${ }^{415}$ This development was a reflection both of repeated interactions with an angry public in the wake of inner-city sliootings and of the increasing professionalization of American policing. Advocacy by civil rights groups, public hearings, and deliberations within police departments, city council halls, and police professional organizations all contributed to the promulgation of these restrictive regulations. Regardless of the source, lowever, the salient fact is that a new standard evolved long before it was imposed from above by the courts.

What is instructive, moreover, is the self-conscious way in whicli the Court addressed the intervenimg social changes. It carefully examined state law and departniental policies both to evaluate "the reasonableness of police procedures under the Fourth Amendment"416 and the practicability of a more restrictive standard. ${ }^{417}$ The Court noted that "the longterm inoveinent has been away froin the [common law] rule" and that "[t]his trend is more evident and impressive when viewed in light of the policies adopted by the police departments themselves." 418 Thus, what the Court found-and what it founded Garner on-was precisely the kind of political and social interactions over time, discussed repeatedly in various deliberative fora, that might reasonably ground constitutional cliange. The change, moreover, liad already been tested in practice before the Court articulated it as a standard that carried with it the force of law and the force of the Constitution.

Froin a trimorphic perspective, the mid-century obsession with the countermajoritarian difficulty seems a little quaint, if not peculiar. ${ }^{419}$ The ordimary course of constitutional jurisgenesis reflects the dynamic nature of the social and cultural processes upon which it depends and, in that very sense, is democratic. In contrast, most conventional theories of judicial review need some knowable, authoritative, foundational inonient of democratic decisionmaking that validates subsequent judicial action.

414. Before Gamer, state and federal courts had almost unanimously upheld the common law deadly force rule. $I d$.

415. Gamer, 471 U.S. at $18-19$ (only $7.5 \%$ of police departments continued to follow common law rule, whereas $86.8 \%$ explicitly did not).

416. Id. at 15 .

417. Id. at 19 ("We would hesitate to declare a police practice of long standing 'unreasonable' if doing so would severely hamper effective law enforcement.").

418. Id. at 18.

419. In a fortlicoming work, I consider the unpact of other, inherently majoritarian influences on the Court and the degree to which they undermine conventional wisdom about the countermajoritarian difficulty. Winter, Upside/Down View, supra note 20. 
Ackerman's dualist constitutionalism is an improvement over its competitors because it recognizes that there is more than one such moment. But it falters because it fails to recognize that these very moments are always in question. (What does it mean? Is that what we fought for? Did the People really agree to that?) There is never a determinate, static thing that the courts can abide by. Trimorphic constitutionalism, on the other hand, recognizes that the courts too are socially situated actors necessarily engaged in the never-ending process of jurisgenerative synthesis. To put the matter as crisply as I know how, Ackerman's railroad metaphor is too quaint and European for a modern, mobile America. Judges are not in the caboose looking backward at determinative moments of constitutional politics. Rather, they are in the thick of it-always on the freeway and always looking forward, backward, and side-to-side at all the other drivers.

\section{Reconstitutive Constitutionalism}

As we have seen, the elaboration of constitutional meaning is unavoidably affected by contemporary assumptions, behefs, crises, and events. In this sense, the idea of the situated Constitution is more conventional than controversial, less tendentious than trite. But the insight that we are situated social beings has potentially more radical, transformative implications for the ways in which we understand, formulate, and practice constitutional law. In the subsections that follow, I suggest ways that an appreciation of situatedness can enhance our understanding of constitutional autonomy. My strategy is to examine three familiar cases-West Coast Hotel v. Parrish, ${ }^{420}$ Brown v. Board of Education, ${ }^{421}$ and Griswold v. Connecticut ${ }^{422}$-and provide new readings that, upon reflection, are how we understood these cases all along. Although each of these cases has received revisiomist readings by important scholars in recent years, I hope to show you that there are yet more vital themes to be extracted from these pivotal decisions.

In each case the themes that prior scholars have missed concern some aspect of our inevitable and unavoidable situatedness-socially, personally, and conceptually. In each case, the relevant autonomy issue-whether that of contract between employer and employee, segregation in public education, or personal privacy-can only be understood as an issue concerning the imteraction between a situated individual and some larger, imterdependent set of social relations. Through this analysis of the three cases, I hope to show that the implications of situatedness, which I have presented as central to our social constitution, are already a

420. 300 U.S. 379 (1937).

421. 347 U.S. 483 (1954).

422. 381 U.S. 479 (1965). 
part of the broader legal canon that is the Constitution-redeeming my preference for building upon the tradition without abandoning the need for significant transformations. Indeed, as I illustrate in the conclusion, the need for significant new directions is urgent.

\section{A Matter of Interdependence-West Coast Hotel}

In West Coast Hotel v. Parrish, ${ }^{423}$ the Court upheld a Washington State statute that provided an administrative systein for the determination of a minimum wage for women. ${ }^{424}$ Part of what placed this case at the heart of the 1937 paradigm shift was the Court's explicit rejection ${ }^{425}$ of its Lochner-era analogue, Adkins v. Children's Hospital. ${ }^{426}$ The more important and interesting question, however, concerns the meaning of the case. There are several ways in which the case can be read, each having substantially different imphications.

Cass Sunstein has suggested that the crux of Lochner and its progeny is their reliance on the common law as the baseline from which to ineasure deviations from governmental neutrality. ${ }^{427}$ In this view, West Coast Hotel

amount[s] to a rejection of the Lochner Court's conception of the appropriate baseline. The key lies in the notion that failure to act would amount to "a subsidy for unconscionable employers." . . The Court's claim is that the failure to impose a minimum wage is not nonintervention at all but simply another form of action-a decision to rely on traditional inarket mechanisms, within the common law framework, as the basis for regulation. ${ }^{428}$

In this reading of West Coast Hotel, the central focus is on the state and the question is by what premises or against what standards will the constitutionality of state action be measured.

As Sunstein acknowledges, this understanding is an application of the legal realists' critique of the private law systenn. ${ }^{429}$ The realists had argued that there was nothing neutral or pre-political about the market because the market was already shaped by state enforcement of the coinmon law rules. And, as Duncan Kemiedy has pointed out, the radical critique of Lochner follows inevitably from this msight. If, as Kemiedy explained, the thrust of classical constitutional formalism was to equate

423. 300 U.S. 379 (1937).

424. Id. at 400 .

425. Id.

426. 261 U.S. 525 (1923).

427. Sunstein, supra note 9, at 873-83.

428. Id. at 880-81 (quoting West Coast Hotel, 300 U.S. at 399).

429. Id. at $883 \mathrm{n} .51$; see also supra text accompanying notes 72-83. This point and its implications for constitutional law were first developed by Duncan Kennedy. Kennedy, supra note 43 , at $1741-56$. 
the biberty of the due process clause with the free will protected by the common law rules, then it follows that the best way to repudiate Lochner would have been to acknowledge the inevitably political nature of both private and public law. ${ }^{430}$

But the post-New Deal Court took a different route in its repudiation of Lochner. Instead of identifying both private and public law as pohtical, the Court divided public law into a politieal (which is to say legislative) and a legal (which is to say judicial) spliere. ${ }^{431}$ Thus, while I don't disagree with Sunstein's theoretieal explanation of Lochner, I do question his reading of West Coast Hotel. I want to suggest, in contrast, that it was neither the state nor the question of neutral baselines tliat preoccupied Chief Justice Hughes in West Coast Hotel. Rather, it was the issue of situatedness and interdependencc that formed the framework for Hughes' reasoning. We can see this inost clearly if we take Hughes' analysis and isolate each of its three more conventional components.

First, Huglies' majority opinion in West Coast Hotel articulated many of the now familiar theines of modern constitutional restraint in econoinic matters: deferencc to the legislative determinations of social need, minimal scrutiny of means/ends rationality, and leeway in allowing the legislature to regulate one step at a time and deal witl less than the entire evil. ${ }^{432}$

Second, a significant aspect of Hughes' opimion in West Coast Hotel was its attention to situation and context. Hughes rejected tlie Lochnerlike claim "tliat adult employees should be deeined competent to inake their own contracts," by "point[ing] out the inequality im the footing of the parties."

The legislature of the State was clearly entitled to consider the situation of woinen in einployment, the fact that they are in the class receiving the least pay, that their bargaining power is relatively weak, and that they are the ready victims of those who would take advantage of their necessitous circumstances. ${ }^{434}$

Thus, Hughes linked the concept of deference to the legislature witl

430. Kennedy, supra note 43 , at 1753-56.

431. See supra text accompanying notes 90-108; see also Kennedy, supra note 43, at 1756.

432. West Coast Hotel, 300 U.S. at 398-400; cf. Williamson v. Lee Optical Co., 348 U.S. 483, 488 (1955) ("It is enough that there is an evil at hand for correction, and that it might be thought that the particular legislative measure was a rational way to correct it."); Railway Express Agency v. New York, 336 U.S. 106, 110 (1949) ("It is no requirement of equal protection that all evils of the same genus be eradicated or none at all.").

433. West Coast Hotel, 300 U.S. at 393.

434. Id. at 398. The opinion continues: "The legislature was entitled to adopt measures to reduce the evils of the 'sweating system,' the exploiting of workers at wages so low as to be insufficient to meet the bare cost of living, thus making their very helplessness the occasion of a most injurious competition." Id. at 398-99. 
its ability to sustain a fact-specific attention to situation and circumstance. ${ }^{435}$

Third, Hughes took the concept of situation a dramatic step further, invoking a theine that would reappear in the most deferential and shameful individual rights cases of the 1940 s and 1950 s. $^{436}$ In rejecting the West Coast Hotel's freedom of contract claim, Hughes asked:

What is this freedom? The Constitution does not speak of freedom of contract. It speaks of liberty and prohibits the deprivation of liberty without due process of law. In prohibiting that deprivation the Constitution does not recognize an absolute and uncontrollable liberty. Liberty in each of its pliases has its history and connotation. But the liberty safeguarded is liberty im a social organization which requires the protection of law against the evils which menace the healtll, safety, morals and welfare of the people. Liberty under the Constitution is thus necessarily subject to restraints of due process, and regulation which is reasonable in relation to its subject and is adopted in the interests of the . community is due process. ${ }^{437}$

There is substantial danger implicit in this view of the situatedness of the individual. Once we recognize that the individual is always located "in a social organization," it is all too easy to conclude that he or she is always "subject to the restramts ... adopted in the interests of the commumity."438 Indeed, this reasoning also works well as an apology for oppression. The lurking totalitarian danger is greatest when the subject's interest is mistakeuly identified with that of the state. ${ }^{439}$ State power is at its zemith when its reach is as unbounded as the interests of any one of its citizens: "The whole is no greater than the sum of all the parts, and when the individual health, safety and welfare are sacrificed or neglected, the State must suffer." $\$ 40$

This is the hidden problem with Sunstein's reading of West Coast Hotel. Underlying his characterization is a two-dimensional picture of

435. In doing so, however, Hughes traded on (and, thus, confirmed) the formalist presupposition that to act judicially is to act on the basis of grounds that are universal and generalizable-that is, "neutral principles."

436. See, e.g., Dennis v. United States, 341 U.S. 494, 524-25 (1951) (affirming convictions under the Smith Act and stating, "[p]rimary responsibility for adjusting the interests which conpete in the situation before us of necessity belongs to the Congress.") (Frankfurter, J., concurring); Minersville School Dist. v. Gobitis, 310 U.S. 586, 594-96 (1940) (compelling Jehovah's Witness schoolchildren to recite pledge to U.S. flag against their established religious beliefs).

437. West Coast Hotel, 300 U.S. at 391.

438. Id.

439. By way of illustration, the late Romanian dictator, Nicolae Ceaucescu, declared in 1986 that "the fetus is the socialist property of the whole society. Giving birth is a patriotic duty, determining the fate of our country. Those who refuse to have children are deserters, escaping the law of natural continuity." ACLU Reproductive Rights Update, Vol. II, No. 4, at 2 (February 16, 1990).

440. West Coast Hotel, 300 U.S. at 394 (quoting Holden v. Hardy, 169 U.S. 366, 397 (1898)). 
the social world: On the horizontal level, there are individuals with opposing interests (the employer and the employee); on the vertical plane, there are the state and its subjects. Viewed this way, with the interest of the einployer pitted against that of the employee, the crucial issue for the state is which side to support. As interpreted by Sunstein, the error of Lochner was to treat as neutral what was in fact the use of the common law to back the einployer with the power of the state. According to this interpretation, West Coast Hotel merely inverted the balance and allowed the state to come down on the other side of the equation.

For Hughes, unlike Sunstem, the question was not which side of a bipolar transaction could permissibly be aided by the state. Rather, Hughes contextualized the transaction by focusing on its larger social situation and the impact of the transaction in the community. In Hughes' understanding of the matter, it was not legal realism but the Depression that had undermined Lochner and its progeny. "There is an additional and compelling consideration which recent economic experience has brought into a strong hight." ${ }^{441}$ The unmistakable lesson of the Depression-and what contributed to the paradigm shift in constitutional law-was that social and economic life is characterized by an unavoidable interdependence.

The exploitation of a class of workers who are in an unequal position with respect to bargaining power and are thus relatively defenseless against the denial of a living wage is not only detrimental to their health and well being but casts a direct burden for their support upon the community. What these workers lose in wages the taxpayers are called upon to pay. The bare cost of living nuust be inet. We may take judicial notice of the unparalleled demands for rehief which arose during the recent period of depression and still continue to an alarming extent despite the degrec of economic recovery which has been achieved. ... [T] here is no reason to doubt that the State of Washington has encountered the same social problem that is present elsewhere. The community is not bound to provide what is in effect a subsidy for unconscionable employers. The community may direct its law-making power to correct the abuse which springs from their selfish disregard of the public interest. ${ }^{442}$

Hughes' point was that no problem could be abstracted from its situatedness in an unavoidably mterdependent social system. Freedom of contract is a subsidy for exploitation because the need for a "livimg wage" won't go away. One way or another, the commumity is called upon to pay. The cost may be exacted in many ways: welfare, crime, hunger, homelessness, or disease. There is no state neutrality, not because the state must choose one side or the other, but because it is already an inter-

441. Id. at 399.

442. Id. at $399-400$ (emphasis added). 
ested party. It is merely the formal embodiment of the commumity upon which unconscionable employers have externalized these costs. The issue that frames West Coast Hotel is neither economic autonomy nor state neutrality. It is, rather, communitarian responsibility.

\section{The Social Construction of the Subject-Brown}

In any account, Brown v. Board of Education ${ }^{443}$ must figure as the preeminent moment of twentieth-century constitutional law. The question, once again, is which of its many possible meanings we should preserve. I will suggest that its lesson of equality is inextricably bound to its appreciation of situatedness. ${ }^{44}$ Before elaborating this position, I will consider an alternative reading recently offered by Bruce Ackerman.

In Ackerman's dualist account of constitutional change, there are three primary inoinents of constitutional lawmaking: the founding in 1787, Rcconstruction, and the New Deal. The challenge for the Court is how to synthesize these three disparate visions of fundamental law. For Ackerman, Brown represents the Court's interpretive synthesis of the egalitarian vision of Reconstruction with the New Deal's affirmance of the activist, regulatory state. He sees "the Court struggling . . . and trying to tell us that new primciples of activist government have decisively undercut the legal forcc of Plessy [v. Ferguson]." "445

The key, according to Ackerman, is to understand that Plessy depended upon two assumptions. ${ }^{446}$ First, Plessy drew a sharp distinction between political equality, which was protected by the fourteenth amendment, and social equality, which could not be enforced by the law. ${ }^{447}$ Second, Plessy viewed the question of the meaning of segregation as " 'solely' a product of private 'choices." "448 On this account, both of Plessy's underlying assumptions were undermined by the New Deal. Certainly, the New Deal vindicated the power of government to address social probleins. With regard to the second assumption, Ackerman notes that: "In repudiating Lochner, the modern Court recognized that the government was an important actor in the process by which groups made their 'choices' in American society." 449 Thus, when Plessy suggested that blacks had "chosen" to interpret Jim Crow as a statement of inferi-

443. 347 U.S. 483 (1954).

444. I do not claim to be the first to note this. Cf. Michelman, supra note 7, at $31 \mathrm{n} .146$ (Brown is "a supreme example of deciding with an eye to context."). But to my knowledge, no one has characterized Brown as a case about the social construction of the subject.

445. Ackerman, Constitutional Politics, supra note 5, at 530 (citing Plessy v. Ferguson, 163 U.S. 537 (1896)).

446. Id. at 531-34.

447. Plessy, 163 U.S. at 544. For Ackerman's discussion of this assumption, see Ackerman, Constitutional Politics, supra note 5, at 530.

448. Ackerman, Constitutional Politics, supra note 5, at 532 (discussing Plessy, 163 U.S. at 551).

449. Id. 
ority, it was ignoring the role of the state itself in establishing this meaning.

The obvious problem with this interpretation is that Brown had nothing to say about the activist state, and only a little to say about the role of the government in establishing meaning. ${ }^{450}$ Ackernan is aware of this difficulty, and he engages it with élan. "What is a public school," he asks, "but a place where government employees are paid to educate children into the 'truth' about social reality ... ?"451 For Ackerman, "[p]ublic schools exemplified the newly legitimated claims of the activist state to shape the conditions under which individual citizens ultimately come to make their mature choices." 452 Masterfully, he finds the same equation between school and activist state in Brown itself: "Just as one might use the history of the White House as a trope to express the rise of the Presidency, Warren used the history of public education to express the rise of the activist welfare state in modern constitutional interpretation." "453 In this view, it was the New Deal insight about the role of the state in creating meaning and shaping private choices that undermined the premises of Plessy.

Ackerinan is correct to see Brown as affected by the New Deal shift in constitutional law. But his reading is premised on a statist principle that is far too strong for the historical record to bear. The public school was hardly the centerpiece of the New Deal, and it is difficult to beheve that it "exeinplified ... the activist state" erations of "We the People." But even nore to the point, there is the awkward problein of squaring his reading with the actual case law that followed the New Deal. For Ackernan, the public school is prototypical of the activist state because it is the institution authorized to induct children into its version of social reality. ${ }^{455}$ This strong statist characterization echoes Justice Frankfurter's majority opinion in Minersville School District v. Gobitis, ${ }^{456}$ the first of the coinpulsory flag-salute cases. In Gobitis, the question was "whether school children ... must be excused from conduct required of all the other children in the proinotion of

450. In fact, the only direct reference to the role of the state in the construction of meaning comes when Chief Justice Warren quotes the lower court finding that: "The impact [of segregation] is greater when it has the sanction of the law; for the policy of separating the races is usually interpreted as denoting the inferiority of the negro group." Brown v. Board of Educ., 347 U.S. 483, 494 (1954) (quoting lower court finding not published in opinion below, Brown v. Board of Educ., 98 F. Supp. 797 (D. Kan. 1951)). Even this passage suggests only that the state contributes by magnifying an already existing psychological meaning.

451. Ackerman, Constitutional Politics, supra note 5, at 533.

452. Id.

453. Id. at 540 .

454. Id. at 533.

455. Id.

456. 310 U.S. 586 (1940). 
national cohesion." 457 Frankfurter held that no exemption was required; to the contrary, he found it enough that the state had chosen this means of promoting good citizenship, inculcating patriotism, and maintaining national unity. ${ }^{458}$

But this strong statist view was quickly repudiated in West Virginia State Board of Education v. Barnette. ${ }^{459}$ Justice Jackson's opinion recognized that local boards of education have "iniportant, delicate, and highly discretionary functions" to fulfill in educating the young. ${ }^{460} \mathrm{Nev}-$ ertheless, he emphasized that these powers must be exercised within constitutional constraints, lest they "strangle the free mind at its source." And there was good reason for the Court's repudiation: The social and political aftermath of Gobitis was marked by both state and private repression. ${ }^{462}$

Far froin legitimating the power of the state to use the public school "to educate children into the 'truth' about social reality," ${ }^{463}$ the lesson internalized by the Court following the New Deal was exactly the opposite: "If there is any fixed star in our constitutional constellation, it is that no official, high or petty, can prescribe what shall be orthodox in politics, nationalism, rehigion, or other matters of opinion or force citizens to confess by word or act their faith therein." 464 As Justices Douglas and Black made explicit in their concurring opinion, the Court had come to see that the power of the state could not be as unrestrained

457. Id. at 595. "Such a sentiment [of national unity] is fostered by all those agencies of the mind and spirit which may serve to gather up the traditions of a people, transmit them from generation to generation, and thereby create that continuity of a treasured common life which constitutes a civilization." Id. at 596.

458. Id. at 595-96.

459. 319 U.S. 624 (1943).

460. Id. at 637 .

461. Id.

462. In the wake of the Court's stamp of approval of compulsory flag salute, religious bigotry and fanatical, unthinking patriotism became rampant. . . . Vigilante committees took it upon themselves to enforce respect for the flag. Between June 12 and June 20, 1940, hundreds of attacks on the [Jehovah's] Witnesses were reported to the Justice Department. . . . With the blessings of an authoritative Supreme Court jndgment, the country's local school officials tightened up on the flag salute requirement. In several states the lower courts treated recalcitrant Witnesses' children as delinquents and confined them to state reform schools.

A. Mason, Harlan Fiske Stone: Pillar of the Law 533 (1956) (footnotes omitted).

463. Ackerman, Constitutional Politics, supra note 5, at 533.

464. Barmette, 319 U.S. at 642 . The Court objected to the communicative as well as the coercive aspects of the practice.

Symbolism is a primitive but effective way of communieating ideas. The use of an emblem or flag to symbolize some system, idea, institution, or personahity, is a short cut from mind to mind.

... Here it is the State that employs a flag as a symbol of adherence to goverumient as presently organized. It requires the individual to communicate by word and sign his acceptance of the political ideas it thus bespeaks.

Id. at $632-33$. 
in inatters of politics and belief as in economics. ${ }^{465}$ The suggestion that Brown solneliow broke with this aspect of the post-New Deal paradigm is further belied by the Court's decisions since Brown. As Robert Cover pointedly observes, the Court subsequently resuscitated and reinvigorated its earlier substantive due process decisions tliat protected the riglit to private schooling and curricular clioice. ${ }^{466}$ Thus, whitever the New Deal contributed to Brown, it was not the strong sense of legitimate statist liegeinony that Ackerman's reading seeins to require.

To understand what the New Deal did contribute to Brown, it is necessary to return to and reconsider what was wrong with the reasoning in Plessy. Plessy was an artifact of constitutional formalisin. Thus, the only equality commanded by the fourteentl amendment was formal equality-that is, "the absolute equality of the two races before the law." 467 The Plessy Court's central premise was its confidence in the relative autonoiny of the subject. Thus, relations between autonomous subjects could not be achieved "by an enforced commingling of the two races. ... If the two races are to ineet on terms of social equality, it must be the result of . . a a voluntary consent of individuals." 468 In this naive view of subject/object relations, the ineaning of the segregation acts was eitlier a matter of the objective text or soinething for eacli and every subject to determine freely for itself: If "tlie elforced separation of the two races stamps the colored race with a badge of inferiority . . . it is not by reason of anything found in the act, but solely because the colored race

465. Accounting for the change in their vote since Gobitis, they explained:

Reluctance to make the Federal Constitution a rigid bar against state regulation of conduct thought inimical to the public welfare was the controlling influence which moved us to consent to the Gobitis decision. Long reflection convinced us that although the principle is sound, its application in the particular case was wrong.

Id. at 643 (Black \& Douglas, JJ., concurring).

466. Certain decisions have aeknowledged the dangerous tendencies of a statist paideia and marked its boundaries through fornal specification of the limits of public meaning. West Virginia v. Barmette, Epperson v. Arkansas, and the School Prayer Cases are the landmarks, though all proceed, in one sense, from Meyer v. Nebraska. . . . [T] he confessional or sacramental eharacter of the utterances in Barnette and the School Prayer Cases distinguish them only in degree from the confessional character of all claims of truth and meaning.

Cover, supra note 178, at 61 (citing Barnette, supra; Epperson v. Arkansas, 393 U.S. 97 (1968); School Dist. v. Schempp, 374 U.S. 203 (1963); Engel v. Vitale, 370 U.S. 421 (1962); Meyer v. Nebraska, 262 U.S. 390 (1923)) (footuotes omitted); see also Wisconsin v. Yoder, 406 U.S. 205,232 (1972). Cover stresses the danger of a too activist state as educator. Instead, he highlights the constitutional value of ensuring educational pluralism.

Were there a single, statist corpns, a state school, a state understanding . . . we might imagine a rather simple participation-protecting rule to guarantee umiversal access to the process. In our own complex nomos, however, it is the manifold equally dignified cominunal bases of legal meaning that constitute the array of commitments, realities, and visions extant at any given time.

Cover, supra note 178 , at 66 .

467. Plessy v. Ferguson, 163 U.S. 537, 544 (1896).

468. Id. at 551 (emphasis added). 
chooses to put that construction upon it." ${ }^{469}$ If the roles were reversed, the Plessy Court was confident, "the white race, at least, would not acquiesce in this assumption." ${ }^{\prime 40}$

Equipped with the blindness to context that afflicts all formalisms, the Plessy Court could shainelessly inaintain that the meaning of segregation could only be a matter of voluntary choice on the part of its victims and, at the very same time, assert that the legislature "is at liberty to act with reference to the established usages, customs and traditions of the people."471 It could do so because-as with Justice Peckham in Lochner ${ }^{472}$ or Justice $\mathrm{O}^{\prime}$ Colmor in Croson ${ }^{473}$-it could neither perceive nor consider the relevance of social context and situation to the question of statutory meaning (as opposed to legislative purpose).

With this introduction, it is easy to see where Ackerman's account goes wrong. According to Ackerman, the Plessy Court's error was to treat as neutral that which was, im fact, the use of the power of the state to back the whites. This is "formalisin-plus-one" - that is, the same twodimensional picture of the social world held by Sunstem: There are individuals with opposing interests (here, whites and blacks), and then there is the state. For those who view the world in this way, the crucial issue will always be the question of which side the state should support. What they miss, however, is the larger social context in which the state and every other social actor is always already enbedded. ${ }^{474}$

The social meaning of segregation was neither a inatter of voluntary choice on the part of blacks (as Plessy would have it) nor the construction of the state through its statutes (as Ackerman seens to suggest). If the segregation statutes had any ineaning whatsoever (whether for black or white), it was because they reflected the already existing and "established usages, custoins and traditions of the people."475 If blacks understood the Jim Crow laws to stigmatize them, it was because the social ineaning of those laws was already established in the social experiences and beliefs of the late nineteenth-century Southeruers. ${ }^{476}$ What was wrong with Plessy was not that it neglected the role of the state im estab-

469. Id. (emphasis added).

470. Id.

471. Id. at 550 .

472. Lochner v. New York, 198 U.S. 45 (1905); see supra text accompanying notes 73-81.

473. City of Richmond v. J.A. Croson Co., 488 U.S. 469 (1989); see supra text accompanying notes 221-22.

474. Tribe's "post-Newtonian" view is no less afflicted by this shortcoming. He is correct to recognize the role of the state and its law in affecting meaning, that people are "in part shaped by political and legal interactions." Tribe, supra note 96 , at 25. But despite all the physics analogies to Newtonian mechanics and relativity theory, his basic position remains two-dimensional. See supra note 223.

475. Plessy v. Ferguson, 163 U.S. 537, 550 (1896).

476. Cf. Black, The Lawfulness of the Segregation Decisions, 69 YALE L.J. 421 (1960). 
hishing meaning, but rather that it failed to recognize that the state could not speak except in terms that were already meaningful to its citizens. ${ }^{477}$ Plessy was undermined by the New Deal because Plessy was premised on a dernal of the contextuality and situatedness of legal meaning. After West Coast Hotel v. Parrish, ${ }^{478}$ the Court could no longer accept that the state was somehow separate from the community that it embodies. ${ }^{479}$ By the same token, it could no longer accept that subjects were "autonomous" and "competent" to choose their own interpretations "free" of all prior social significance. ${ }^{480}$

By the time of Brown, moreover, a carefully planned hitigation strategy had brought to the Court a series of cases that made the essentially situated nature of the educational experience all but imescapable. In Sweatt v. Painter, ${ }^{481}$ the Court had considered whether the newly opened, segregated black law school was "equal" to the existing, exclusively white University of Texas Law School. What Warren found most relevant to Brown was that, in making that comparison, the Sweatt Court "rehed in large part on "those qualities which are incapable of objective ineasurement but which inake for greatness in a law school." "482 Although it had considered the number of faculty and the size of the libraries, the Sweatt Court had stressed the quality and reputation of the faculty, the position and influence of the alumm, and the students' opportunity to interact with various segments of society. ${ }^{483}$ Similarly, what Warren found most important about McLaurin v. Oklahoma, ${ }^{484}$ the companion case to $S$ weatt, was its stress on the importance of the black student's "ability to study, to engage in discussions and exchange views with other students." 485

477. Cf. Winter, Transcendental Nonsense, supra note 12, at 1180 (law can speak only in the normative language of the culture). Instead, Plessy presumed that legislative meaning was only a matter of formal linguistic structures-and whatever other meanimg the autonomous subject inight project into it. See 163 U.S. at 551.

478. 300 U.S. 379 (1937).

479. As Pat Williams observes:

The rules may be color-blind but people are not. The question remains, therefore, whether the law can truly shed, or exist apart from the color-conscious society in which it exists, as a skeleton is devoid of fiesh; or whether law is the embodiment of society, either the creation or reflection of a particular citizenry's arranged complexity of relations.

Williams, supra note 225, at 2142.

480. In the accoumt I ain providing, Ackerman's basic point-that Brown is a synthesis of the constitutional ineaning of Rcconstruction and the New Deal-remains true. What changes is the ineaning of the New Deal and, thus, of the synthesis.

481. 339 U.S. 629 (1950).

482. Brown, 347 U.S. at 493 (quoting Sweatt, 339 U.S. at 634).

483. Sweatt, 339 U.S. at 633-34.

484. 339 U.S. 637 (1950). In McLaurin, the Court invalidated the policy of the University of Oklahoma graduate school of education that allowed the admission (under court order) of a black student but required him to sit at separate tables in separate areas of the hibrary, classrooms, and cafeteria. Id. at 642 .

485. Brown, 347 U.S. at 493 (quoting McLaurin, 339 U.S. at 641). 
In short, what Warren culled from these precedents was the pertinence to educational quality of situation, acculturation, and social interaction. Warren mvoked precisely this point in rejecting Plessy. "Such considerations apply with added force to children in grade and high schools. To separate thein . . . solely because of their race generates a feeling of inferiority as to their status in the community that may affect their hearts and minds in a way unlikely ever to be undone."486 Warren's breakthrough, however, was to see the deeper, more profound implications of situatedness:

Today, education is perhaps the most important function of state and local governments. Compulsory school attendance laws and the great expenditures for education both demonstrate our recognition of the importance of education to our democratic society. It is required in the performance of our most basic public responsibilities, even service in the armed forces. It is the very foundation of good citizenship. Today it is a primcipal instrnment in awakening the child to cultural values, in preparimg him for later professional training, and in helping him to adjust normally to his environinent. In these days, it is doubtful that any child may reasonably be expected to succeed in life if he is deried the opportunity of an education. ${ }^{487}$

This passage is a frank and total recognition of the role of education in the social construction of the subject. ${ }^{488}$ Education is "a principal instrument" for inculcating cultural values in children; it is a necessary precondition for "the performance of our inost basic public responsibilities," without which the child cannot "adjust normally to his environment" or "succeed in life." 489 "Separate educational facilities are inherently unequal," 490 not because the state shapes that meaning. ${ }^{491}$ Separate educational facilities are inherently unequal because, without access to an education that reflects the full range of the social situation for which the

486. Id. at 494 .

487. Id. at 493 .

488. This passage does begin with an invocation of the state's role in education. Cf. Ackerman, Constitutional Politics, supra note 5, at 534 (claiming that Warren presents the public scliool as a "paradigmatic expression of the inodern republic's activist commitment to the general welfare of its citizens"). However, Warren's focus is not on the activist regulatory state; indeed, the state is not Warren's subject at all. Education is the subject of the passage's first few sentences. State and local governments are important because they provide that education. Brown, 347 U.S. at 493 ("the most important function of state and local governmeuts"). Indeed, Warren ends the paragraph with just such an equivocation: "Such an opportunity, where the state has undertaken to provide it, is a right which must be made available to all on equal terms." Id. (empliasis added).

489. Brown, 347 U.S. at 493.

490. Id. at 495 .

491. The strongest support for this reading of Brown appears in the lower court finding quoted by Warren just before his disapproval of Plessy: "Segregation with the sanction of law . . . has a tendency to [retard] the educational ... development of negro children ...." Id. at 494 (bracketed material in original). Oddly enough, Ackerman never discusses this passage. 
student is being acculturated, the socially constructed subject cannot participate fully in the social and pohtical world.

On this reading, the conceptual significance of Brown is its einphasis on the importance of situatedness to an understanding of constitutional autonomy: Because we are situated social beings, equality cannot be equal except im context. Because the individual is formed in the interaction with the physical and social world, meaningful constitutional autonomy requires affirmative access to the processes by which both the individual and the commumity are constituted. As Cover notes:

Precisely because the school is the point of entry to the paideic and the locus of its creation, the school inust be the target of any redemptive constitutional ideology. Through education, the social bonds form that give rise to autonomy, to the jurisgenerative process. In education are the origins of the processes in which "law" is given meaning. ${ }^{492}$

It is this appreciation of what is truly at stake in the practices of segregation that provides the logic of Warren's conclusion "that in the field of public education the doctrine of 'separate but equal' has no place."493

\section{Everything's Connected to Everything Else-Griswold}

Justice Douglas' opinion in Griswold v. Connecticut ${ }^{494}$ is inuch maligned for its talk of "penumbras" and "emanations" as well as for the lack of any explicit textual support for the right to privacy that it invokes. Ackerman's dualist defense of Griswold sees the case as a selfconscious effort by the Court to wrestle with the implications of the New Deal's repudiation of Lochner's property-based conception of individual hiberty. ${ }^{495}$ This interpretation is obviously right, as even a cursory reading of the opinion confirms. ${ }^{496}$ Moreover, Ackerman is correct to see Griswold's move to privacy as rooted in Brandeis' early work on the subject. ${ }^{497}$ In fact, Griswold is only one installment in the post-New Deal Court's shift to a privacy-based conception of individual liberty in a number of different doctrinal areas. The process in fact began in the first amendment context with $N A A C P$ v. Alabama ${ }^{498}$ and continued in the fourth amendment context with Warden v. Hayden ${ }^{499}$ and Katz v.

492. Cover, supra note 178 , at 66 .

493. Brown, 347 U.S. at 495.

494. 381 U.S. 479 (1965).

495. Ackerman, Constitutional Politics, supra note 5, at 536-45.

496. See Griswold, 381 U.S. at 481-83.

497. Ackerman, Constitutional Politics, supra note 5, at 544-45 n.193 (discussing Warren \& Brandeis, The Right to Privacy, 4 HARV. L. Rev. 193 (1890)); see also Olmstead v. United States, 277 U.S. 438, 478-79 (1928) (Brandeis, J., dissenting) (invoking "the right to be let alone" and "the privacy of the individual").

498. 357 U.S. 449,462 (1958) (protecting the right of "privacy in one's associations").

499. 387 U.S. 294, 304 (1967) ("We have recognized that the principal object of the Fourth Amendment is the protection of privacy rather than property ...."). 


\section{United States. ${ }^{500}$}

Although Ackerman's analysis of Griswold is right on target, it misses the case's trimorphic, socially contingent dimension. Griswold must also be situated in its time and in its social milieu. The line from Griswold through Eisenstadt v. Baird ${ }^{501}$ to Roe v. Wade ${ }^{502}$ can only be understood when placed in historical context-the development of the birth control pill im the late 1950s and the revolution in sexual mores that took place in the $1960 \mathrm{~s}$. But even if one stays within the confines of the text of Griswold itself, Ackerman's reading fails to mine all the riches of Douglas' opinion.

Everyone is familiar with the eloquent (and somewhat iroinc) passage with which Douglas closes the opmion: "Marriage is a coming together for better or for worse, hopefully enduring, and intimiate to the degree of being sacred. It is an association that promotes a way of life, not causes; a harmony in hing, not pohitical faiths; a bilateral loyalty, not commercial or social projects."503 Ackerman stresses the phrase about "bilateral loyalty, not commercial or social projects," 504 which he sees as the linchpm of Griswold's "discriminating view of the Lochner era."505 And surely he is correct to say that the Court was rejecting any role in economic affairs. But why einphasize only what the case is not about? What is Douglas endorsing? What is his:affirmative claim? And how does that relate to the New Dcal?

We can answer these questions with a closer reading of the Griswold opinion. One of the striking things is the manner in which the opinion is framed by a focus on relationships. Following the recitation of the facts, the first legal issue to be discussed is the standing of the professionals to raise the personal rights of their inarried patients. ${ }^{506}$ The Court concludes that there is third-party standing because of the "professional relationship": "The rights of husband and wife . . . [will likely be] diluted or adversely affected unless ... considered in a suit involving those who have this kind of confidential relation to them."507 When Douglas rejects the Lochner-like overtones of some of the appellants' argu-

500. 389 U.S. 347,353 (1967) (wiretapping "violated the privacy upon which [Katz] justifiably relied").

501. 405 U.S. 438 (1972) (state law prohibiting distribution of contraceptives to unmarried persons but not to unarried persons violates equal protection clause).

502. 410 U.S. 113 (1973).

503. Griswold, 381 U.S. at 486.

504. Id., quoted in Ackerman, Constitutional Politics, supra note 5, at 541.

505. Ackerman, Constitutional Politics, supra note 5, at 541.

506. The appellants in Griswold were, respectively, the Executive Director of the Planned Parenthood League of Connecticut and a physician who worked at its center. Griswold, 381 U.S. at 480. They were represented by Professor Thomas I. Emerson of Yale Law School. Id. at 479.

507. Id. at 481. For a discussion of the concept of "relational standing," see Winter, The Metaphor of Standing, supra note 12, at 1485-86, 1501-02. 
ments, ${ }^{508}$ he nevertheless goes forward because: "This law ... operates directly on an intimate relation of husband and wife and their physician's role im one aspect of that relation." 509 So too, when Douglas expresses the Court's ultimate conclusion, he makes this relational focus explicit: The Connecticut statute must be struck down because, " $m$ forbidding the use of contraceptives rather than regulating their manufacture or sale, [it] seeks to achieve its goals by means having a maximum destructive impact upon that relationship." 10 Indecd, what else could Griswold be about if not relationships? One doesn't use a contraceptive when one is alone.

To understand Griswold, then, one must see that the heart of the case is the recognition that privacy is relational or associational. In the conventional understanding, privacy is understood as an individual, atolmistic right-m Justice Brandeis' words, "the right to be let alone." 11 In constrast, Justice Douglas already sees what many feminists have since come to emphasize: that privacy is not a matter of separation and intrusion, but rather of association and choice. Privacy means inore than the right to exclude others; it necessarily - that is, necessary to us as social beings-includes the right to share intimacy with others of our choice. As Douglas later explained:

Those who wrote the Bill of Rights believed that every individual needs both to communicate with others and to keep his affairs to himself. That dual aspect of privacy ineans that the individual should have the freedom to select for himself the time and circunstances when lie will share his secrets with others and decide the extent of that sharing. ...

It was in that tradition that we held in Griswold that lawmakers could not, as respects husband and wife at least, make the use of contraceptives a crime. ${ }^{\text {s12 }}$

Thus, it is this other-directed, situated "dual aspect of privacy" that Douglas invokes in Griswold, just as West Coast Hotel ${ }^{513}$ invoked the situated, interdependent consequences of all economic and social actions. This is why the unenumerated right that Douglas considers to be the common thread in Meyer v. Nebraska, ${ }^{514}$ Pierce v. Society of Sisters, ${ }^{515}$

508. Griswold, 381 U.S. at 481-82.

509. Id. at 482.

510. Id. at 485 (emphasis changed from original).

511. Olmstead v. Umited States, 277 U.S. 438, 478 (Brandeis, J., dissenting).

512. Warden v. Hayden, 387 U.S. 294, 323-24 (1967) (Douglas, J., dissenting) (citation and footnote omitted).

513. 300 U.S 379 (1937).

514. 262 U.S. 390 (1923) (striking down state statute that forbade the teaching of foreign languages).

515. 268 U.S. 510 (1925) (striking down state statute that forbade parents from sending their children to private schools). 
NAACP v. Alabama, ${ }^{516}$ and $N A A C P$ v. Button, ${ }^{517}$ is not individual privacy, but rather "the 'freedom to associate and privacy in one's associations." "'518

Of course, privacy retains its connotation of freedom from intrusion by the state; we would not "allow the pohce to search the sacred precincts of marital bedrooms for telltale signs of the use of contraceptives." 19 But much more is at stake. Douglas views marriage as an "association that promotes a way of life."520 It is obvious that privacy is destroyed when the state intrudes on the space of the marital bedroom.

Yet it is also problematic, even if less so, to coerce the abandonment of actions that arise from common life in a dedicated space within the normative world. The effect of this latter form of coercion is to destroy the experience and interpersonal faith that, as much as "reason," are constitutive of our understanding of normative worlds. 521

Privacy is only meaningful as an associational right. If meaning is gronnded in a form of life, then forms of life must be both fostered and

516. 357 U.S. 449 (1958) (holding compelled disclosure of membership in an organization violates right of free association).

517. 371 U.S. 415 (1963) (holding that state statute prohibiting proper solicitation of legal business violated first and fourteenth amendinents).

518. Griswold, 381 U.S. at 483 (quoting NAACP v. Alabama, 357 U.S. 449, 462 (1958)). For a sophisticated argument that the common law "privacy" tort is, in essence, a social construct constitutive of the individual's social personality, see Post, The Social Foundations of Privacy: Community and Self in the Common Law Tort, 77 CAL1F. L. REV. 957 (1989). "The tort rests not upon a perceived opposition between persons and social life, but rather upon their interdependence." Id. at 959.

519. Griswold, 381 U.S. at 485.

520. Id. at 486.

521. Cover, supra note 178 , at 49 ; see also Miclielman, supra note 96 , at 1533 . Cover's point demonstrates what is wrong about Jennifer Nedelsky's argument that we must do without the boundary inetaphor if we are better to reconceptualize our idea of "self." Nedelsky, supra note 323, at 176-77. Although I agree with her that it is necessary to reformulate our concept of constitutional autonomy in a more relational way, it remains useful and important to maintain some conception of boundary against state power. Otherwise, we too easily fall prey to the conception of the collective that swallows everything - the lurking totalitarian danger in Hughes' reasoning in West Coast Hotel. See discussion supra text accompanying notes $436-40$. Nedelsky seems to recognize this point in her interpretation of Starhawk's use of the boundary metaplor as "a way of organizing patterns of respect and expressing the capacity for commitınent." Nedelsky, supra note 323, at 175. Even so, she imsists that the boundary metaphor is necessarily distorting. Id. at 176-78.

Nedelsky fails to recognize that it is sle, not Lakoff and Johnson, who essentializes the meaning of the BODY-AS-CONTAINER metaplior. Id. at 178-79 (discussing G. LAKOFF \& M. JoHNSON, supra note 137 , at 29 ). What she does not understand is that, no matter how putatively "natural" a particular inetaphor might be, its meaning is nondeterminate and socially contingent. See Winter, The Cognitive Dimension, supra note 12, at 2245-55. Thus, even if we unavoidably experience the body as a container, it does not follow that we do not also experience the body as a conneetion to others. Nor does it follow that, if we understand the "self" via the BODY-AS-CONTAINER inetaphor, we cannot also understand that what the self "contains" is, necessarily, our relations with others. See discussion supra text accompanying notes 232-39; see also Winter, supra note 284. 
supported with some measure of legal protection. ${ }^{522}$ Because we are situated social beimgs, real autonomy can have no other meanimg.

And, in its own way, Griswold makes the point by the very unorthodoxy of its methodology. It declines to locate this associationalprivacy right in a discrete constitutional command. Rather, it locates the right of privacy of relationships im an entire, constitutional way of life.

[S]pecific guarantees in the Bill of Rights have penumbras, formed by einanations from those guarantees that help give them life and substance. Various guarantees create zones of privacy. The right of association contained in the penumbra of the First Amendinent is one, as we have seen. The Third Amendment in its prohibition against the quartering of soldiers "in any house" . . . is another facet of that privacy. The Fourth Amendinent exphicitly affirms the "right of the people to be secure in their persons, houses, papers, and effects, against unreasonable searches and seizures." The Fifth Amendment in its Self-Incrimination Clause enables the citizen to create a zone of privacy which government may not force him to surrender to his detriment.

We have had inany controversies over these penumbral rights of "privacy and repose." ... The present case, then, concerns a relationship lying within the zone of privacy created by several fundamental constitutional guarantees. 523

Thus, Ackerman is correct that synthesis occurs at the heart of Griswold. This synthesis, however, is more breathtaking than normally realized. Douglas synthesizes an entire nomos, an entire constitutional ethos. ${ }^{524}$ It is a situated nomos marked by a social, relational ethic. And what he finds at the center of this normative world is not a self alone, but situated humans im an intimate relationship.

522. And, so, I agree with Michelman on Bowers v. Hardwick, 478 U.S. 18 (1986). See discussion at supra note 179.

523. Griswold, 381 U.S. at 484-85 (emphasis added) (citations omitted).

524. In a passage omitted from the block quote above, Douglas invokes the Court's earlier synthetic effort in Boyd v. Umited States, 116 U.S. 613 (1886). Griswold, 381 U.S. at 484-85. Boyd was a pre-Lochner case, still operating with a property-based conception of liberty. Nevertheless, Boyd was a pivotal case for the Brandeisian vicw of personal hiberty that the post-New Deal Court inherited. See Olmstead v. United States, 277 U.S. 438, 474 (1928) (Brandeis, J., dissenting) (Boyd is "a case that will be remembered as long as civil hiberty lives in the United States."). Moreover, Boyd's synthesis employs much the same sense of conceptual interrelatedness as Douglas', although it invokes a somewhat less felicitous metaphor.

It is not the breaking of his doors, and the rummaging of his drawers, that constitutes the essence of the offence; but it is the invasion of his indefcasible right of personal security, personal liberty and private property .... Breaking into a house and opening boxes and drawers are circumstances of aggravation; but any forcible and compulsory extortion of a man's own testimony or of his private papers .... is within the condemnation of th[e] judgment [in Entick v. Carrington]. In this regard the Fourth and Fifth Amendments run almost into each other.

Boyd, 116 U.S. at 630 (emphasis added), quoted in Griswold, 381 U.S. at 484-85 n.*. 
Robert Cover reminds us that "[a] legal tradition is . . . part and parcel of a complex normative world." 525 Every normative world has its own essential, conceptual ecology: It is "a system with an overall structure, where effects cannot be localized-that is, where something in one part of the system affects things elsewhere in the system." 526 Our normative world, no less than any other, is already built up with the sedimented value of the past. At the same time, it is always an invitation to a sequel, each new decision "taking its place in relation to what went before and further cutting a channel for what is to come."527

If I have done my job well, my exploration of these three cases has only revealed what you, as a situated member of the tradition, already know to be true. At the same time, however, I have invited you to see these cases in a way that presents a different path to a different future. Of course, one consequence of the fact that we are situated im a tradition is that these cases are already weighted down with other, more restrictive meanings. But there is no objective truth that stands behind the more conventional versions of these cases.

Like our language, our tools, our customs, our clothes, they are instruinents, invented for a definite purpose, which fii]nd themselves hittle by hittle burdened with an entirely different function. A complete analysis of this change in meaning has to be made, ... and a program of action established consequent upon it. ${ }^{528}$

Thus, if we do share the situated versions of West Coast Hotel, Brown, and Griswold, they can be the vehicles of an alternative constitutional paradigm that reflects the mexorability of our situatedness: "Shared examples can serve cognitive functions commonly attributed to shared rules."529 These cases can be taught and elaborated as the constitutional exemplars that reveal the ways in which we constitute each other and the ways in which we constitute an ecologically related social system.

The challenge that remains is to formulate the politics that will realize the potential of these cases. The challenge that remains is the hard work of a reconstitutive constitutionalism.

\section{VI \\ WeARING OUT THE SHEATH}

In the epigraph at the start of this essay, I quote Merleau-Ponty's stark, disquieting metaphor: "The blade wears out the sheath, and in the end no one is satisfied, neither the philosopher nor the powers that

525. Cover, supra note 178 , at 9.

526. G. LAKOFF, supra note 28 , at 113.

527. Irvine v. California, 347 U.S. 128, 147 (1954) (Frankfurter, J., dissenting).

528. M. MERLEAU-PONTY, DiALECTIC, supra note 1, at 227 (discussing capitalist institutions).

529. Kuhn, supra note 336, at 482. 
be."530 It is a powerful image, one that simultaneously evokes the concepts of situatedness and incommensurability. By way of summary, I want to offer three different readings of this image.

Each of the positions that dommate the current debate in constitutional scholarship prescribes a different antidote for the specter of constitutional law in a conservative age. One position would constrain the Court with a governing theory, either Grand or otherwise. A second would render it harmless, demystifying and delegitimating it by means of the "law is politics" and indeterminacy critiques. A third would wrap it in normative dialogue in the hope that, if the blade is sufficiently swathed, we will somehow fail to feel its sting. In this first reading, constitutional authority is the blade and our flagging theoretical efforts the hapless sheatl.

I have argued that these strategies are wrongheaded. The alternative is the inore difficult route of making constitutional meaning-from the ground up, so to speak. More difficult, but more promising. This alternative engages us in the arduous task of a trnly constitutional pohtics. In this second, nore hopeful reading, the relentless capacity for jurisgenesis is the blade and the stylized strictures of legal convention the inevitably less sturdy sheath. This reading, however, will please neither those who long for a stable, logical order nor those who constitute hierarchical legal authority - that is, neither the philosopher nor the powers that be.

In this reading, the relative indeterminacies and inevitable instabilities of the law are a positive good. In the absence of objective foundations, would we have it any other way?

We do not gain from the working operations of history that comprehensive understanding which would reveal the true solution. At best we rectify errors which occur along the way, but the new scheme is not immune to errors which will have to be rectified anew. History elimimates the irrational; but the rational remains to be created and to be imagined, and it does not have the power of replacing the false with the true. ${ }^{531}$

The periodic cycle of normalization, crisis, and paradigm shift is, thus, a necessary hoineostatic phenomenon. A inultiplicity of diverse and conflicting meanings is an adaptive mechanism, part of a continuing process by which the social group revises its public ineanings. ${ }^{532}$ Jurisgenesis is

530. M. Merleau-PonTY, Dialectic, supra note 1 , at 72.

531. Id. at 22.

532. Cf. Kuhn, Reflections on My Critics, in CRITICISM AND THE GrowTH OF KNOWLEDGE, supra note 186 , at 241 :

[M]y other critics inevitably fail to note a special feature which follows from taking the normal group rather than the normal mind as unit. ... Given a group all the members of which are committed to choosing between alternative theories and also to considering [shared] values ... while making their choice, the concrete decisions of individual members in individual cases will nevertheless vary. Group behaviour will be affected deeisively by 
both relentless and endless, and that is how it should be.

There is a third reading, and it is the one I find most frightening. In this reading, our individualist self-conception is the blade; and the social, cultural, and physical environinent, the sheath in which we are situated. As long as we fail to recognize the import of our situatedness, we run the all too serious risks of fragmentation and self-destruction. The best way to express this is to recount the results of a Gallup poll pubhished on New Year's Day, 1990. When asked about their jobs, finances, families, and the overall quality of their hives in the year 2000 , overwhelming majorities (between 75 and 82 percent of those polled) thought that things would be better for them and their families. ${ }^{533}$ When asked about a series of social and economic problems, however, the same respondents were not so sanguine.

Large majorities expected by 2000 to see increases in the rate of inflation (74 percent), the crime rate ( 71 percent), poverty (67 percent), homelessness (62 percent), and environmental pollution (62 percent).

Shightly smaller majorities anticipated a worsening of the unemployment rate ( 59 percent), alcohol and drug abuse problems ( 58 percent), and the divorce rate (58 percent)..$^{534}$

What I want to know is: Where do these people think they will be hiving ten years from now? And, for that inatter, where will we?

the shared commitments, but individual choice will be a function also of personality, [and] education ... . To many ... this variability seems a weakness .... When considering the problems of crisis ... I shall want, however, to argue that it is instead a strength. If a decision must be inade under circumstances in which even the inost deliberate and considered judgement may be wrong, it may be vitally unportant that different individuals decide in different ways. How else could the group as a whole hedge its bets?

See also Cover, The Uses of Jurisdictional Redundancy: Interest, Ideology, and Innovation, 22 WM. \& MARY L. REv. 639 (1981); Cover \& Aleinikoff, Dialectical Federalism: Habeas Corpus and the Court, 86 YALE L.J. 1035 (1977); Michelman, supra note 96, at 1528-29.

533. Kagay, 90's, in Poll: A Good Life Amid Old Ills, N.Y. Times, Jan. 1, 1990, at 8, col. 3.

534. Id. at 8 , col. 4 . 
